\title{
IMMUNSZENZOR FEJLESZTÉSE ÉLELMISZER- ÉS KÖRNYEZETANALITIKAI FELHASZNÁLÁSRA
}

MAJERNÉ BARANYI KRISZTINA

Témavezetôn: Adányiné Dr. Kisbocskói Nóra DSc

Budapest

2015 


\section{A doktori iskola}

megnevezése: $\quad$ Élelmiszertudományi Doktori Iskola

tudományága: Élelmiszertudományok

vezetője: $\quad$ Dr. Felföldi József

Egyetemi tanár, $\mathrm{PhD}$

Budapesti Corvinus Egyetem

Élelmiszertudományi Kar

Fizika-Automatika Tanszék

Témavezető: $\quad$ Adányiné Dr. Kisbocskói Nóra

Tanácsadó, DSc

NAIK-ÉKI

A jelölt a Budapesti Corvinus Egyetem Doktori Szabályzatában elöírt valamennyi feltételnek eleget tett, az értekezés mühelyvitájában elhangzott észrevételeket és javaslatokat az értekezés átdolgozásakor figyelembe vette, azért az értekezés nyilvános vitára bocsátható. 
A Budapesti Corvinus Egyetem Élettudományi Területi Doktori Tanácsának 2015. év június 09-ki határozatában a nyilvános vita lefolytatására az alábbi bíráló Bizottságot jelölte ki:

\section{BÍRÁLÓ BIZOTTSÁG:}

Elnöke

Biacs Péter, DSc, BCE

Tagjai

Cserhalmi Zsuzsanna, PhD, NAIK-ÉKI

Pokol György, DSc, BMGE

Salgó András, DSc, BMGE

Simonné Sarkadi Lívia, DSc, BCE

Opponensek

Halász Anna, DSc, NAIK-ÉKI

Rezessyné Szabó Judit, PhD, BCE

Titkár

Takács Krisztina, PhD, NAIK-ÉKI 


\section{TARTALOMJEGYZÉK}



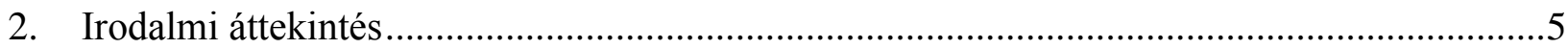

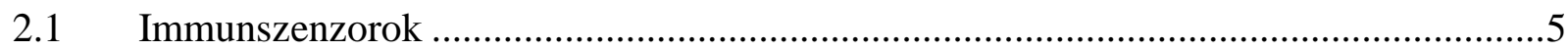

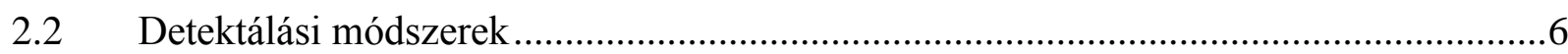

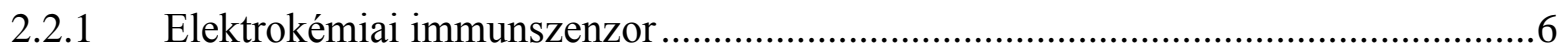

2.2.1.1 Potenciometriás mérésen alapuló rendszerek...............................................

2.2.1.2 Amperometriás mérésen alapuló rendszerek................................................

2.2.1.3 Konduktometriás mérésen alapuló rendszerek..............................................

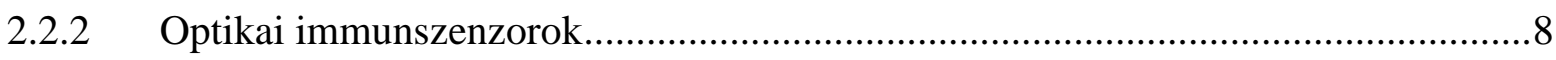

2.2.2.1 Jelöléses optikai immunszenzorok ............................................................. 8

2.2.2.2 Jelölésmentes optikai technikák ...................................................................



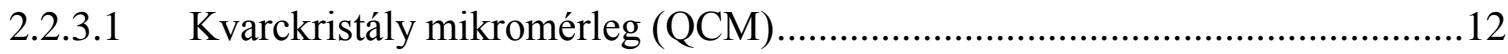

2.2.3.2 Mikro- és nanomechanikus erőkarok (mikrokonzolok) ..................................13

2.3 Optikai hullámvezető fénymódus spektroszkópia technika elvi alapjai.......................13

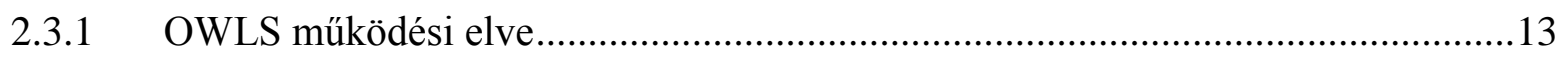

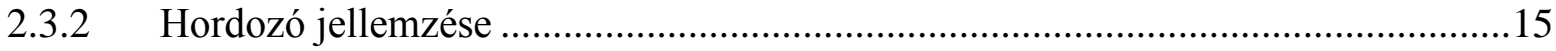

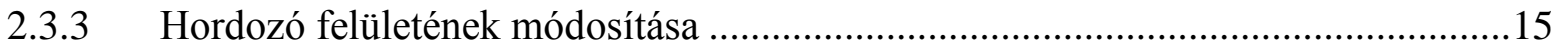

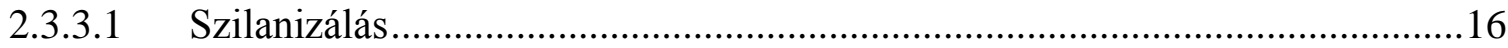

2.3.4 Biomolekulák rögzítésének lehetőségei a szenzorfelületen .................................17



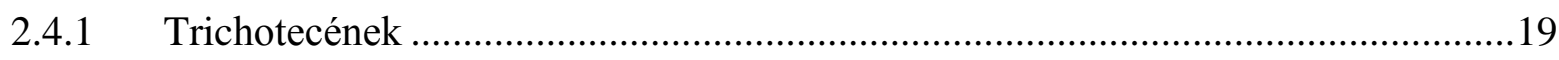

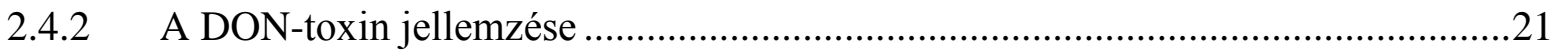

2.5 DON meghatározásra alkalmas analitikai módszerek .............................................22

2.5.1 Nagymüszeres analitikai technikák ................................................................22

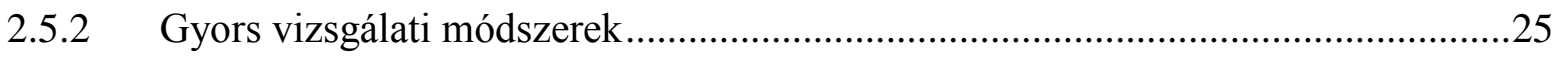



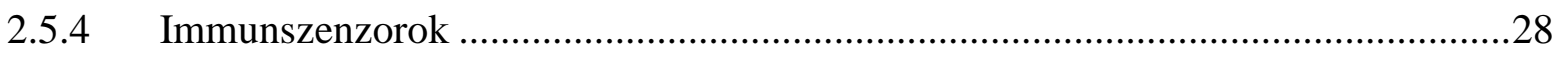

2.6 Vitellogenin mint biomarker a környezetanalitikában .............................................29

2.6.1 Hormonális müködésre ható vegyületek ............................................................29

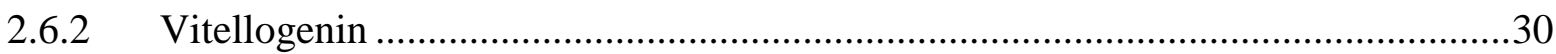

2.6.3 Vitellogenin meghatározásra alkalmazott technikák .........................................31

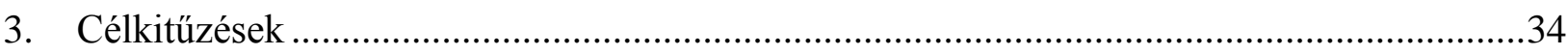

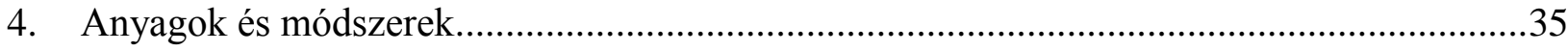




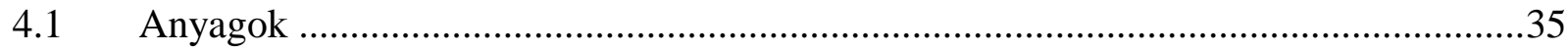

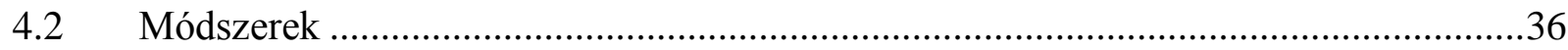

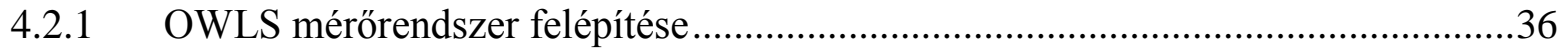

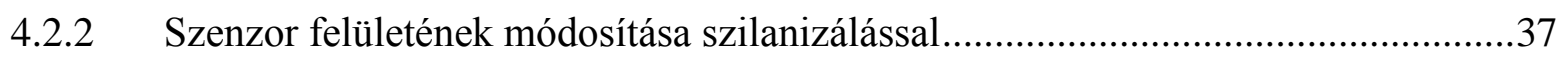

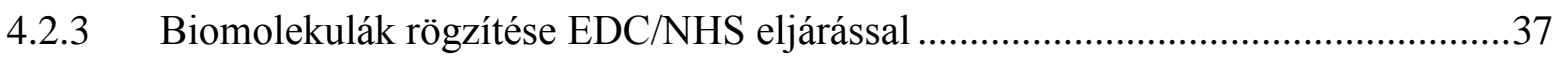

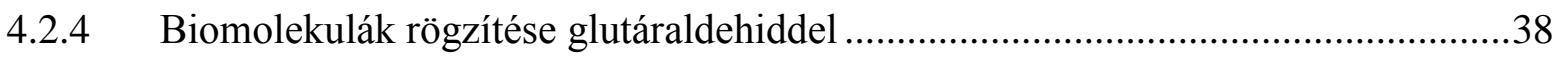

4.2.5 Fehérje koncentráció meghatározása Bradford-módszerrel ....................................38





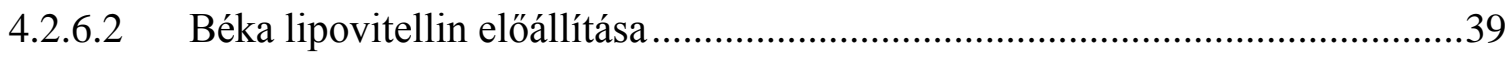

4.2.7 DON-fehérje konjugátum ellenőrzése izoelektromos fókuszálással ......................39

4.2.8 Lipovitellin preparátumok ellenőrzése SDS-PAGE módszerrel ............................39

4.2.9 ELISA eljárás referencia vizsgálatokhoz .......................................................40

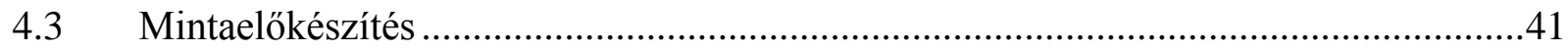

4.3.1 Búzaminták előkészítése DON méréshez...........................................................41

4.3.2 Ponty minták előkészítése Vtg méréshez .........................................................41

4.3.3 Béka minták előkészítése Vtg méréshez ..........................................................41

4.4 Alkalmazott számítástechnikai és statisztikai módszerek .........................................41

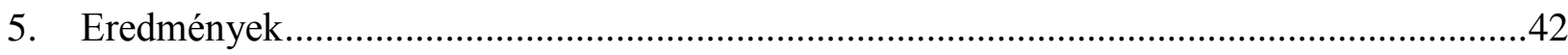

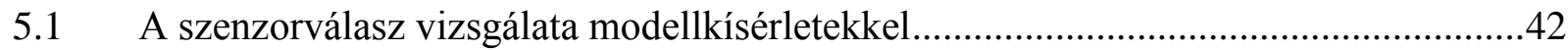

5.1.1 Különböző fehérjék rögzítése során kialakult rétegvastagságok vizsgálata............42

5.1.2 Szenzorválasz vizsgálata az analitikum molekulatömege és koncentrációja

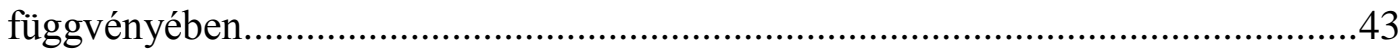

5.1.3 Szenzorválasz reakcióideje és a mérés pontossága ...........................................45

5.1.4 Különböző méretü küvetták alkalmazásának mérésre gyakorolt hatása .................46

5.2 DON meghatározására alkalmas immunszenzor fejlesztése .....................................47

5.2.1 A szenzorfejlesztéshez szükséges immunanyagok előállítása..............................47

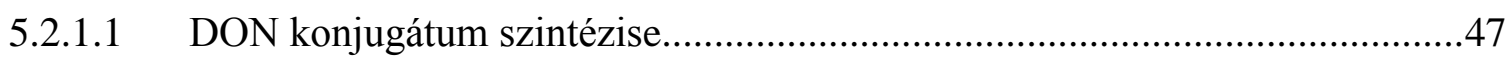

5.2.1.2 Fehérjefrakciók ellenőrzése izoelektromos fókuszálással..............................47



5.2.1.4 DON antigénspecifikus tisztított IgG előállítása...........................................48

5.2.1.5 DON specifikus antitestek antigénnel szembeni aktivitásának vizsgálata.......49

5.2.2 Immunszenzor fejlesztés DON kimutatására .................................................50

5.2.2.1 Szenzor felületének módosítása és fehérjék immobilizációja ..........................51

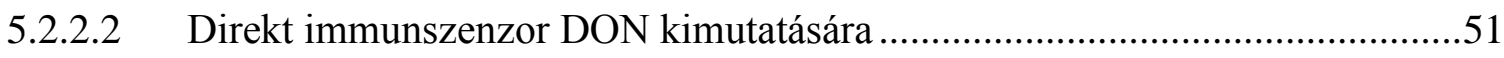


5.2.2.3 Kompetitív immunszenzor fejlesztése DON meghatározásra... .52

5.2.2.3.1 Poliklonális antitest mennyiségének meghatározása .................................53

5.2.2.3.2 A rögzített antigén optimális koncentrációjának meghatározása..................54

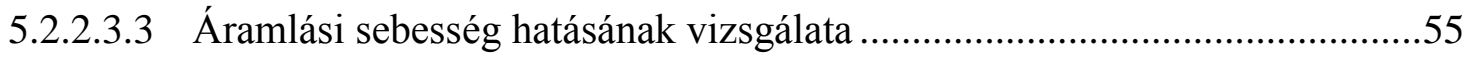

5.2.2.3.4 Inkubációs hőmérséklet hatásának vizsgálata..........................................55



5.2.2.3.6 DON meghatározására alkalmas immunszenzor statisztikai paraméterei ...56



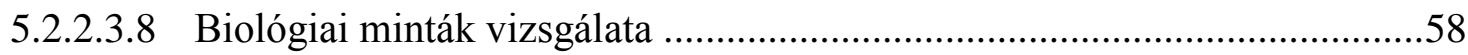

5.3 Immunszenzor fejlesztés vitellogenin meghatározásra ............................................59

5.3.1 A szenzorfejlesztéshez szükséges immunanyagok előállítása...............................59

5.3.1.1 Lipovitellin fehérjefrakciók ellenőrzése SDS-PAGE vizsgálattal ...................59

5.3.1.2 Ponty és béka lipovitellin specifikus poliklonális antitest előállítása ..............61

5.3.1.3 Ponty lipovitellin specifikus antitest antigénnel szembeni aktivitásának vizsgálata

5.3.1.4 Béka lipovitellin specifikus antitest antigénnel szembeni aktivitásának

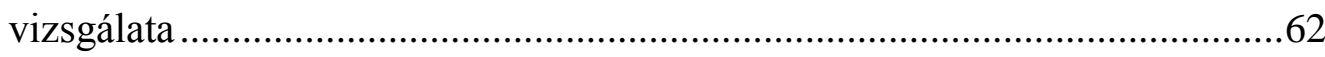

5.3.2 Immunszenzor fejlesztése ponyt vitellogenin kimutatásra .................................62

5.3.2.1 Direkt mérési módszer ponty vitellogenin mérésére......................................62

5.3.2.2 Kompetitív immunszenzor kifejlesztése ponty Vtg meghatározásra ...............64

5.3.2.2.1 Alkalmazott poliklonális antitest koncentrációjának meghatározása ..........64

5.3.2.2.2 A rögzített antigén koncentráció meghatározása ........................................65

5.3.2.2.3 Az áramlási sebesség hatása ................................................................66

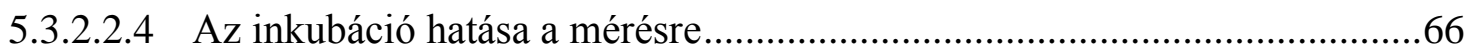

5.3.2.2.5 Dinamikus méréstartomány meghatározása ...........................................67

5.3.2.2.6 Ponty lipovitellin antitest szubsztrát-specifitása .....................................68

5.3.2.2.7 A ponty minták mátrixhatása, Vtg meghatározása biológiai mintákból......69

5.3.3 Immunszenzor fejlesztése béka vitellogenin kimutatásra ...................................71

5.3.3.1 Szenzorfelület módosítása, fehérjék immobilizálása ....................................71

5.3.3.2 Direkt mérési módszer béka vitellogenin mérésére .....................................71

5.3.3.3 Kompetitív immunszenzor kifejlesztése béka vitellogenin meghatározáshoz.72

5.3.3.3.1 Alkalmazott poliklonális antitest koncentrációjának meghatározása ..........72

5.3.3.3.2 A rögzített antigén optimális koncentrációjának meghatározása.................73



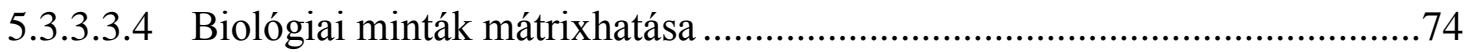


5.3.3.3.5 Biológiai minták vizsgálata .75

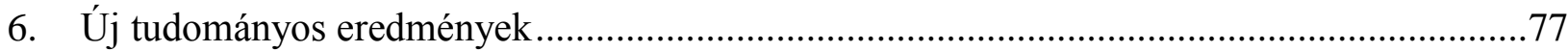

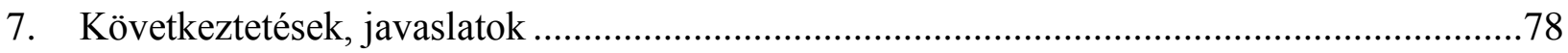



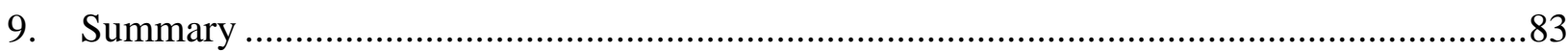



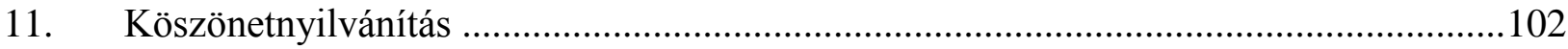




\section{RÖVIDÍTÉSEK JEGYZÉKE}

API

APTS

BSA

CMD

DAS

DON

ECD

EDC

EDCs

ELISA

EN-MOS

ESI

FD

FDA

FIA

FID

FI-IA

FITC

FP

GC

GOPS

GOx

HPLC

HPLC-QTOF-MS

IACs

$\mathrm{IgG}$

ISFET

ITO

LC-MS

LFD

LOD

Lpv

MIP

MIPPy

MS

MZI atmoszférikus nyomású ionizáció - atmospheric pressure ionization amino-propil-trietoxi-szilán - (3-Aminopropyl)-triethoxysilane marhaszérum albumin - bovine serum albumin karboxi-metil-dextrán - carboxymethyl-dextran diacetoxi-szcirpenol - diacetoxyscirpenol deoxynivalenol - deoxynivalenol elektronbefogási detektor- electron capture detector 1-etil-3-(3-dimetil-amino-propil)-karbodiimid - 1-Ethyl-3-(3dimethylaminopropyl)-carbodiimide endokrin zavaró hatású vegyület - endocrine disrupting chemical enzimhez kapcsolt immunoszorbens vizsgálat - enzyme-linked immunosorbent assay

elektromos orr- fémoxid félvezető - electronic nose-metal oxide semi-conductor sensors

elektrospray ionizáció - electrospray ionization

fluoreszcens detektor - fluorescence detector

amerikai Élelmiszer és Gyógyszerfelügyeleti Hatóság - Food and Drug Administration

átfolyó injektálásos analitika - flow injection analysis

lángionizációs detektor - flame ionization detector

átfolyó befecskendezéses immunkötődéses vizsgálat - flow-injection immunoassay

fluoreszcein izotiocianát - fluorescein isothiocyanate

fluoreszcens polarizáció - fluorescence polarization

gázkromatográfia - gas cromatography

$\gamma$-glicidoxi-propil-trimetoxi-szilánnal $\quad-\quad \gamma$-glycidoxypropyl

trimethoxy silane

glükózoxidáz - glucose oxidase

nagyhatékonyságú folyadékkromatográfia - high-performance liquid chromatography

nagyhatékonyságú folyadékkromatográfia- kvadrupól repülési idő hibrid tömegspektrometria - high-performance liquid chromatography-hybrid quadrupole time-of-flight mass spectrometry

immunaffinitás oszlopok - immunoaffinity columns

immunoglobulin - immunoglobulin

ion érzékeny térvezérlésű tranzisztor - ion-sensitive field-effect transistor

indium ón-oxid - indium tin oxide

folyadékkromatográfia-tömegspektroszkópia - liquid

chromatography-mass spectrometry

síkáramlású teszt - lateral flow device

kimutatási határ - limit of detection

lipovitellin - lipovitellin

molekuláris lenyomatú polimerek - molecularly imprinted polymer

molekuláris lenyomatú polipirrol - molecularly imprinted polymer polypyrrole

tömegspektrometria - mass spectrometry

Mach-Zender interferométer - Mach-Zehnder interferometer 
NEO

NHS

NIV

OVA

OWLS

PEEK

QCM

RIfS

RT-PCR

SDS-PAGE

SPE

SPR

T-2 toxin

TIRE

TIRF

TLC

TOPAS

TRIS

Vtg neosolanid - neosolaniol

N-hidroxi-szukcinimid - N-hydroxysuccinimide

nivalenol - nivalenol

ovalbumin - ovalbumin

optikai hullámvezető fénymódus spektroszkópia - optical waveguide lightmode spectroscopy

poliéter-éter-keton - polyether ether ketone

kvarckristály mikromérleg - quartz crystal microbalance

reflexiós interferencia spektroszkópia - reflectometric interference spectroscopy

reverz transzkripciós polimeráz-láncreakció - reverse transcription polymerase chain reaction

nátrium-dodecil-szulfát poliakrilamid gélelektroforézis - sodium dodecyl sulfate polyacrylamide gel electrophoresis

szilárd fázisú extrakció - solid-phase extraction

felületi plazmon rezonancia - surface plasmon resonance

$\mathrm{T}-2$ toxin $-\mathrm{T}-2$ toxin

teljes belső visszaverődéses ellipszometria - total internal reflection ellipsometry

teljes belső visszaverődéses fluoreszcencia - total internal reflection fluorescence

vékonyréteg kromatográfia - thin layer chromatograpy

cikloolefin kopolimer - cyclic olefin copolymer

2-amino-2-hidroxi-metil-propán-1,3-diol - 2-Amino-2-

hydroxymethyl-propane-1,3-diol

vitellogenin - vitellogenin 


\section{BEVEZETÉS}

Napjainkban az élelmiszeriparban a fogyasztók által támasztott egyre magasabb igényekkel párhuzamosan növekednek az élelmiszerbiztonsági és minőségi követelmények. A globalizáció és az élelmiszerek szabad kereskedelme miatt elengedhetetlen a biztonságos élelmiszer előállítás feltételeinek megteremtése. A szennyező anyagok kimutatása, a kockázatbecslés és kockázatelemzés ma nélkülözhetetlen eleme az élelmiszerbiztonsági elöírásoknak az emberek egészségének megóvása érdekében. A gyártók számára ezért elengedhetetlen az élelmiszer-előállítás teljes folyamatát végigkísérő (a nyersanyagtól a késztermék fogyasztó elé való kerüléséig) folyamatos, gyors ellenörzés. A gabonák mikotoxin szennyezettsége világszerte fontos humán- és állategészségügyi kockázatot jelent. Magyarországon a fusárium penészgombák által termelt toxinszennyezés a leggyakoribb, ezen belül elsősorban a deoxynivalenol szennyezettség jelent problémát. A globális felmelegedésnek, illetve az iparszerü mezőgazdasági termelési gyakorlatnak köszönhetően a gabonák fuzáriumos kiégése hatalmas gazdasági veszteséget okoz, és egyben a szennyezett gabonák takarmányként történő felhasználásával az állattenyésztési hozamban jelentős visszaesést eredményez, míg a szennyezett gabonából készített élelmiszer közvetlen humán egészségkárosító hatású.

Az ipar gyors fejlődésével, az iparszerü mezőgazdaság és állattenyésztési gyakorlat alkalmazásával egyre növekszik a különböző vegyszerek, gyógyszerek, növényvédőszerek alkalmazása, ami nem csak élelmiszerbiztonsági kérdéseket vet fel, de komoly környezetvédelmi problémát is jelent. Az utóbbi évtizedben kerültek a figyelem központjába a hormonrendszerre ható anyagok (endokrin zavaró hatású anyagok, EDCs), melyek súlyos hormonháztartási zavarokat idézhetnek elő, elsősorban szaporodási problémákat okozva. Jelenlétükre különösen a vízi élőlények érzékenyek. Az esetek jelentős részében növényvédőszereket, műanyagokat és humángyógyszereket találtak felelősnek e hatás kialakulásáért.

Ahhoz, hogy ezen anyagokra irányuló kockázatbecslést és értékelést el tudjuk végezni, olyan analitikai módszerek szükségesek, amelyek alkalmasak gyorsan, olcsón, nagy érzékenységgel és szelektivitással meghatározni ezen anyagok jelenlétét és koncentrációját. A hagyományos analitikai módszerek sok esetben nem alkalmazhatók a minőségbiztosítási rendszerek kiépítésénél, mint például a nagyhatékonyságú folyadékkromatográfia (HPLC), gázkromatográfia (GC), tömegspektrometria (MS), HPLC-MS, GC-MS, hiszen drágák, lassúak, jól képzett szakembereket és sok esetben bonyolult minta előkészítést igényelnek. Az elmúlt három évtizedben előtérbe kerültek a hagyományos analitikai módszerek mellett a sorozatvizsgálatokra alkalmas, gyors, nagy érzékenységű automatizálható módszerek fejlesztése.

E módszerek közül kiemelkedő a bioszenzor fejlesztésekben elért eredmények. Áttörő 
eredményeket elsősorban a klinikai, környezetvédelmi analitikában és a biotechnológiai folyamatok nyomon követésében értek el, de számos élelmiszeriparban alkalmazható szenzor is született. Ma a szenzorkutatás elsősorban az immunszenzor fejlesztések irányába indult meg.

Munkámmal 2007-ben kapcsolódtam be a KÉKI, majd 2014. január 1-től a Nemzeti Agrárkutatási és Innovációs Központ Élelmiszer-tudományi Kutatóintézetének optikai hullámvezető fénymódus spektroszkópia (OWLS) alapú bioszenzor kutatási témáiba. Az intézetben a 2000-es évek elején indult el az OWLS technika alkalmazási lehetőségeinek kutatása, melynek eredménye számos új mérési módszer kidolgozása volt (Székács et al., 2003, Trummer et al., 2001, Levkovets et al., 2004, Adányi et al., 2007). A GVOP-3.1.1-2004-05-0429/3.0 „Immunteszt és immunszenzor kidolgozása endokrin zavaró hatások biomarker fehérjéjének kimutatására” című pályázat, illetve a GVOP-3.1.1.-2004-05-0283/3.0 „Élelmiszerbiztonság a bor termékpályán" című pályázat keretén belül elsősorban élelmiszer és környezeti minták vizsgálatára alkalmas különböző OWLS alapú immunszenzorok kifejlesztése volt a cél. A disszertáció egyik felében deoxynivalenol (DON) kimutatására alkalmas OWLS alapú immunszenzor fejlesztés eredményeit mutatom be. A kialakított szenzorral búzaliszt minták vizsgálatát végeztem el. A dolgozat második felében vitellogenin (Vtg), mint hormonrendszert zavaró környezetszennyezők kimutatására alkalmas biomarker meghatározására kifejlesztett immunszenzorral történő mérések eredményeit foglalom össze. 


\section{IRODALMI ÁTTEKINTÉS}

\subsection{Immunszenzorok}

Immunszenzorok a bioszenzorok azon speciális csoportja, ahol a rögzítendő, specifikus biológiailag érzékeny anyagként antitestet vagy antigént alkalmaznak. A szenzor müködése alapvetően két folyamatból áll: a receptor felületén végbemenő specifikus antigén-antitest kötődés kialakulásából, melyet molekuláris felismerő folyamatnak is nevezünk, majd ezt követi a jelátalakító folyamat, mely a specifikus kötés kialakulása közben bekövetkezett változásokat (elektrokémiai, optikai, mágneses, piezoelektromos stb.) detektálja és azt mérhető, feldolgozható és tárolható elektromos jellé alakítja (Ruan et al., 2002).

Az immunszenzorokat az immunreakció során kialakult komplex detektálására alkalmazott módszer szerint csoportosíthatjuk (Patel, 2002). Megkülönböztethetünk jelöléses, illetve jelölésmentes immunszenzort. A jelölésre akkor van szükség, ha az antigén-antitest komplex kialakulása nem jár könnyen detektálható termékkel, ezért mesterséges jelölőt, például radioaktív izotópot, enzimet, fluoreszcens vagy kemilumineszcens molekulát, mágneses nanorészecskéket alkalmaznak. A leggyakrabban használt enzimjelöléses eljárásokban elsősorban torma peroxidázt, glükóz oxidázt, $\beta$-galaktozidázt vagy alkalikus foszfatáz jelzőenzimet használnak. A jelöléses immunszenzor esetén kétféle mérési módszer, a szendvics illetve a kompetitív módszer alkalmazható. A szendvics eljárás során az antigénnel specifikusan reagáló ellenanyagmolekulákat kötünk a szenzor felületére. Az ily módon rögzített ellenanyag specifikusan köti az antigént, és ezért az antigén komplex mintából izolálható és kimutatható. Az ellenanyag-antigén kötődés az antigénnel specifikusan reagálni képes jelzett ellenanyaggal mutatható ki. A keletkezett jel az analitikum koncentrációjával arányosan növekszik. A kompetitív módszer során a mérendő antigént tartalmazó mintához a vizsgált antigénnel azonos, de jelölt antigénmolekulákat adunk, melyek a mérendő antigénmolekulákkal versenyeznek az antitest kötőhelyeiért. A jelzett antigén kötődését a nem jelzett antigént tartalmazó ismeretlen minta gátolja. A gátlás mértéke a gátló anyag koncentrációjával arányos, de nagymértékben függ az ellenanyag és az antigén között kialakult kötés erősségétől, az ellenanyag affinitásától is. A módszer igen kis mennyiségü ellenanyag és antigén kimutatására és mennyiségi meghatározására alkalmas (Pokol et al., 2011). A jelöléses immunszenzor esetén a jelölő alkalmazása drágábbá és bonyolulttá teszi a rendszert. Az utóbbi időben ezért a kutatás egyre inkább a jelölésmentes technikák fejlesztése felé irányult, ahol az immunreakciót nem további kémiai, biokémiai reakciók segítségével detektáljuk, hanem a folyamat során bekövetkező fizikai változásokat jelölésmentesen mérjük igen érzékeny mérési technikák alkalmazásával (Bange et al., 2005). Jelölésmentes technikánál is kétféle, direkt és 
indirekt mérési módszert különböztethetünk meg. Direkt módszernél a szenzor felületén közvetlenül az antitestet rögzítjük és vizsgáljuk a minta által adott jel nagyságát. A technika elönye az egyszerüség, ugyanakkor kis molekulák esetén az érzékenység sok esetben nem megfelelö. A kompetitív immunszenzornál az antigének, vagy kis molekulák esetén a fehérjével képzett konjugátuma kerül rögzítésre. A mérések során a mintákat meghatározott mennyiségü antitestet tartalmazó szérummal keverjük össze, inkubáljuk, majd injektáljuk a rendszerbe. Csak a szabadon maradt antitestek kötődnek a felszínre, így a jelintenzitás fordítottan arányos a vizsgált anyag koncentrációjával.

\subsection{Detektálási módszerek}

Míg a bioszenzor szelektivitását és specificitását elsősorban a rögzített biológiailag érzékeny anyag határozza meg, addig az érzékenységet az alkalmazott érzékelö-jelátalakító rendszer befolyásolja (Leca-Bouvier et al., 2005). Az immunszenzorokban az érzékelés alapját egy részről a célmolekula és a felismerő elem között létrejövő specifikus reakció képezi. A felismerés alapja, hogy a célmolekula és a felismerő elem között létrejövő kapcsolat fizikai-kémiai változást okoz a rendszerben, mely változás azután egy alkalmas jelátalakító segítségével detektálható és mérhető. Az alkalmazott detektorok szerint megkülönböztethetünk elektrokémiaioptikai-, piezoelektromos immunszenzorokat.

\subsubsection{Elektrokémiai immunszenzor}

Az elektrokémiai immunszenzorok az antigén-ellenanyag kötődést követően az alkalmazott jelölő vegyület és az elektroaktív szubsztrát kémiai reakciója során bekövetkezett változásokat követi nyomon. Vizsgálhatja a rendszerben kialakuló potenciálkülönbséget (potenciometria), a rajta átfolyó áramot (amperometria), illetve a rendszer vezetőképességének változását (konduktometria) is.

\subsubsection{Potenciometriás mérésen alapuló rendszerek}

A potenciometriás detektorok a referencia, illetve az indikátor elektród közti potenciálkülönbséget mérik. A mérés során a referenciaelektród potenciálja állandó, míg az indikátor elektród potenciálja függ a mérni kívánt anyag koncentrációjától. Napjaink egyik legígéretesebb potenciometriás immunszenzora az ion érzékeny térvezérlésű tranzisztor (ISFET) alapú immunszenzor, ahol az antitestet az ionszelektív elektród felszínét borító membránon rögzítik, és az antigén-antitest komplex képződése során bekövetkezett változásokat regisztrálja a jelátalakító. Starodub és mtsai (2000) simazin gyomirtó kimutatására alkalmas ISFET-alapú 
immunszenzort fejlesztettek ki, ahol az ISFET felületére simazin elleni poliklonális antitestet rögzítettek Staphylococcus eredetü protein-A segítségével. A vizsgálatban kétféle mérési módszert alkalmaztak. Kompetitív módot, ahol a natív és peroxidázzal jelölt simazin molekulák versengtek az ISFET felületére kötött antitestek kötőhelyeiért, valamint a szekvenciális telítés technikát (sequential saturation of antibodies). A megkötődött peroxidáz aktivitását aszkorbinsav és hidrogén-peroxid jelenlétében mérték. Kompetitív rendszer esetén a simazin kimutatási határa $1,25 \mathrm{ng} / \mathrm{ml}$, a lineáris tartomány $5-175 \mathrm{ng} / \mathrm{ml}$ volt, míg szekvenciális telítés technikát alkalmazva az érzékenység jóval nagyobb volt, 0,65 ng/ml kimutatási határral és 1,25-185 ng/ml lineáris tartománnyal. Az IFSET immunszenzorként való alkalmazásának jelentősége a miniatürizálásban és többcsatornás rendszer kialakításának lehetőségében rejlik.

\subsubsection{Amperometriás mérésen alapuló rendszerek}

$\mathrm{Az}$ amperometriás rendszerek müködése az elektroaktív ionok oxidációján vagy redukcióján alapszik. A mérés során a munkaelektród potenciálja állandó, és azt vizsgálják, hogy az analitikum koncentrációjának hatására hogyan változik az átfolyó áram erőssége. A vizsgált anyag koncentrációja és az áramerősség között egyenes arányosság áll fenn. Az amperometriás szenzorok gyorsak, ugyanakkor szelektivitás terén a rendszerben jelen lévő elektroaktív anyagok redox potenciálja a meghatározó, így a mért áram a mintában lévő több anyag együttes jeléből tevődik össze. Gyors, egyszerü, olcsó alkalmazhatóságának köszönhetően a legelterjedtebb detektálási mód a bioszenzorok körében. Micheli és mtsai (2005) tejből aflatoxin $M_{1}$ kimutatására alkalmas amprometriás immunszenzort fejlesztettek ki, ahol a monoklonális antitestet közvetlen az elektród felszínén (szitanyomott-elektród) rögzítették, kompetitív mérési módszert alkalmazva, enzim jelölöként pedig tormaperoxidázt használtak. A rendszer kimutatási határa $25 \mathrm{pg} / \mathrm{ml}$, lineáris tartománya $30-160 \mathrm{pg} / \mathrm{ml}$ volt. A rendszer nagy előnye, hogy a vizsgálat a tej centrifugálásán kívül semmilyen egyéb mintaelőkészítési eljárást nem igényel. Badea és mtsai (2004) szintén tej aflatoxin $M_{1}$ tartalmának kimutatására fejlesztettek ki egy átfolyó injektálásos immunoassay-en (FI-IA) alapuló amperometriás immunszenzort. Az automatizált rendszer egyesítette az átfolyó injektálásos vizsgálatra jellemző gyorsaságot és reprodukálhatóságot az immunkémiai reakciókra jellemző érzékenységgel és szelektivitással.

\subsubsection{Konduktometriás mérésen alapuló rendszerek}

Konduktometriás mérésen alapuló detektálási módszert használják legkevésbé a bioszenzorok körében, habár olcsó és egyszerü. Csak olyan rendszernél alkalmazható, ahol a reakciók során ionok képződnek vagy a rendszer ionokat fogyaszt, megváltoztatva az oldat vezetőképességét. Ezt a folyamatot mérik a vezetőképesség időbeni változásának 
nyomonkövetésével. A módszer hátránya, hogy a vezetőképességet a rendszerben jelen lévő összes ion vezetőképessége adja, ezért nem specifikus. Aflatoxin $\mathrm{B}_{1}$ kimutatására alkalmas konduktometrián alapuló immunszenzort fejlesztett ki Liu és mtsai (2006), ahol tormaperoxidázt és aflatoxin $B_{1}$ specifikus antitesteket rögzítettek arany nanorészecskékkel funkcionalizált mikroelektródokon. A rendszer kimutatási határa $0,1 \mathrm{ng} / \mathrm{ml}$ aflatoxin $\mathrm{B}_{1}$ volt.

\subsubsection{Optikai immunszenzorok}

Napjainkban az immunszenzor kutatásban az optikai jelátalakítók használata vette át a vezető szerepet, mert miniatürizálhatóak, olcsók, nagy érzékenységü müszerek. Az optikai immunszenzorral történő detektálás alapját az adja, hogy az immunkomplex kialakulása során UVVIS abszorpció, biolumineszcencia/kemilumineszcencia, fluoreszcencia/foszforeszencia, visszaverődés, szóródás vagy refraktív indexbeli változás történik. Az optikai immunszenzorokon belül megkülönböztethetünk jelölt, illetve jelölésmentes immunszenzorokat. Az alábbiakban csak a legfontosabb optikai szenzorokat mutatom be röviden.

\subsubsection{Jelöléses optikai immunszenzorok}

A jelölt immunszenzorok az antigén - antitest kötődés detektálására egy nagy érzékenységgel meghatározható jelölő molekulát tartalmaznak. Jelölőként használhatók enzimek (pl.: peroxidáz, luciferáz), fluorofórok (pl.: FITC), fluoreszcens nanokristályok (quantum dots) stb.

\section{Fluoreszcencia alapú rendszerek}

A fluoreszcencia olyan jelenség, amelynek során bizonyos molekulák adott energiájú fényt nyelnek el. Ennek a folyamatnak a következtében magasabb energiájú állapotba kerülnek, majd bizonyos idő alatt visszaállnak nyugalmi helyzetükbe, de közben a felvett energia egy részét leadják fénykibocsátás formájában. Az energia egy része a folyamat során elveszik, a kibocsátott fény kisebb energiájú, vagyis nagyobb hullámhosszú lesz, mint a gerjesztő fény. A fluoreszcencia alapú immunszenzorok fluoreszcens molekulákat alkalmaznak az antigén-antitest kötődés vizsgálatához, melyek vagy közvetlenül kötődnek a célmolekulához, vagy a mérés során, mint indirekt jelölő vesznek részt. Spektrométerrel a fluoreszcencia intenzitása mérhető, így az antigénantitest reakció által indukált fluoreszcencia intenzitás változás vizsgálatából a célmolekula mennyisége számítható (Schobel et al., 2000).

Maragos és mtsai (1999) aflatoxin és fuminozin meghatározására alkalmas fluoreszcens immunszenzort hozott létre, ahol az antitesteket optikai szálon rögzítették. Az aflatoxin meghatározás nem igényelt külön jelölést, hisz természetes fluoreszcens tulajdonsággal rendelkezik, míg a fuminozin $\mathrm{B}_{1}$-et fluoreszcein izotiocianáttal (FITC) jelölték. Standard 
fuminozin $B_{1}$ oldatokat alkalmazva a kimutatási határ $10 \mathrm{ng} / \mathrm{ml}$ volt, míg kukoricából egyszerü metanolos extrakciót követve $3,2 \mu \mathrm{g} / \mathrm{g}$, ha az extrahált mintát további affinitás kromatográfiás tisztításnak vetették alá, akkor $0,4 \mu \mathrm{g} / \mathrm{g}$ kimutatási határt értek el. Aflatoxin $\mathrm{B}_{1}$ esetében a kimutatási határ $2 \mathrm{ng} / \mathrm{ml}$ volt.

A fluoreszcens immunszenzorok közt a teljes belső visszaverődéses fluoreszcencia (TIRF) szenzorok igen ígéretesek. A TIRF a fénynek azt a különleges tulajdonságát használja fel, hogy amikor a fény egy töröfelületre egy kritikusnál nagyobb szögben érkezik (63 üveg/víz határfelületnél), teljes visszaverődést szenved, így a fény közvetlenül nem hatol be a törőfelszín alá, azonban a törőfelszínt jelentő üveg-víz határvonalon mégis átjut egy evaneszcens hullámnak nevezett elektromágneses hullám. Az evaneszcens hullám a visszaverődő fény hullámhosszától és beesési szögétől függően 50-200 nm mélységben képes behatolni a mintába és gerjeszteni az ott lévő fluorofórokat. A technika alkalmas akár egy molekula valós idejű vizsgálatára (Engström et $a l ., 2006)$. Barzen és mtsai (2002) egy TIRF alapú, hordozható optikai immunszenzort fejlesztettek ki, felszíni vizek minőségének monitorozására (RIANA-river analyser). A rendszer előnye, hogy egy mintából egyszerre háromféle szennyező anyag kimutatására alkalmas és automatizált. A TIRF technika alapjait és bioszenzorként való széleskörü felhasználását számos tudományos cikk ismerteti (Mallat et al., 2001, Rodriguez-Mozaz et al., 2004, Tschmelak et al., 2006, Tschmelak et al., 2005).

\subsubsection{Jelölésmentes optikai technikák}

A jelölésmentes immunszenzoroknál az antigén-antitest komplex kialakulása következtében létrejövő fizikai változások közvetlenül vizsgálhatók (Zhang, 2008).

\section{Optikai hullámvezető fénymódus spektroszkópia (OWLS)}

Az integrált optikai hullámvezető szenzor alapját a chip adja, amely egy kb. 0,5 mm vastagságú üveglemezre felvitt, 200 nm vastagságú, nagy törésmutatójú szilícium-dioxid - titándioxid $\left(\mathrm{SiO}_{2}-\mathrm{TiO}_{2}\right)$ rétegből áll, amelyben finom optikai rácsot (2400 vonal/mm) alakítanak ki. Ezen optikai rács segítségével történik a méréshez használt lineárisan polarizált He-Ne lézer fény becsatolása a hullámvezető rétegbe. Az optikai hullámvezető felületén végbemenő változások (pl. adszorpció, deszorpció stb.) a határréteg optikai tulajdonságait módosítja, ami a hullámvezető vékonyréteg effektív törésmutatójának megváltozását eredményezi. Az effektív törésmutató megváltozása a becsatolási szög (rezonanciaszög) változásához vezet. A rezonanciaszögeket mérve (módusspektrum) a kérdéses közeg törésmutatója, vastagsága, anyag egységnyi felületre eső tömege számítható (Thiefenthaler, 1989) (1. ábra). Az OWLS szenzorok müködésének elve bővebben a 2.3.1. fejezetben olvasható. 


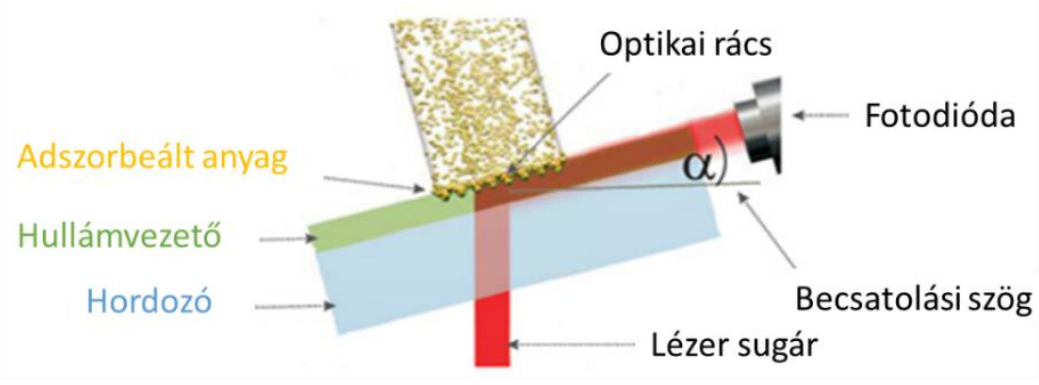

1. ábra: Optikai hullámvezető fénymódus spektroszkópia müködési elve

(www.exasol.hu)

\section{Felületi plazmon rezonancia (SPR) spektroszkópia}

A felületi plazmon rezonancia (SPR) spektroszkópia a teljes visszaverödésen alapuló speciális spektroszkópiai módszer. A technika azon a jelenségen alapul, hogy ha a teljes visszaverődés egy optikai elem (szigetelő) és egy vékony (10 nm, a behatolási mélységnél lényegesen kisebb) fémes vezetőréteg határán következik be, akkor a fémben az evaneszcens hullámok az elektronok oszcillációját idézik elő. Egy speciális szög alatt a hullám fémben való „elnyelődésének” maximuma van, ilyenkor a visszavert fény intenzitása minimális. Ennek a „völgypontnak” a szögfüggése meghatározható, síkban poláros fény alkalmazásával akár $10^{-5}$ fok érzékenységgel. A fém felületén rögzített biomolekulákhoz (pl.: antitest, antigén, DNS, RNS) való bekötődés megváltoztatja a felülettel közvetlenül érintkező réteg törésmutatóját, ami az SPR szög értékét kismértékben eltolja. Az analitikai és kinetikai információt a rezonanciaszög időbeli változásának nyomonkövetése szolgáltatja (Gyurcsányi, 2005) (2. ábra).

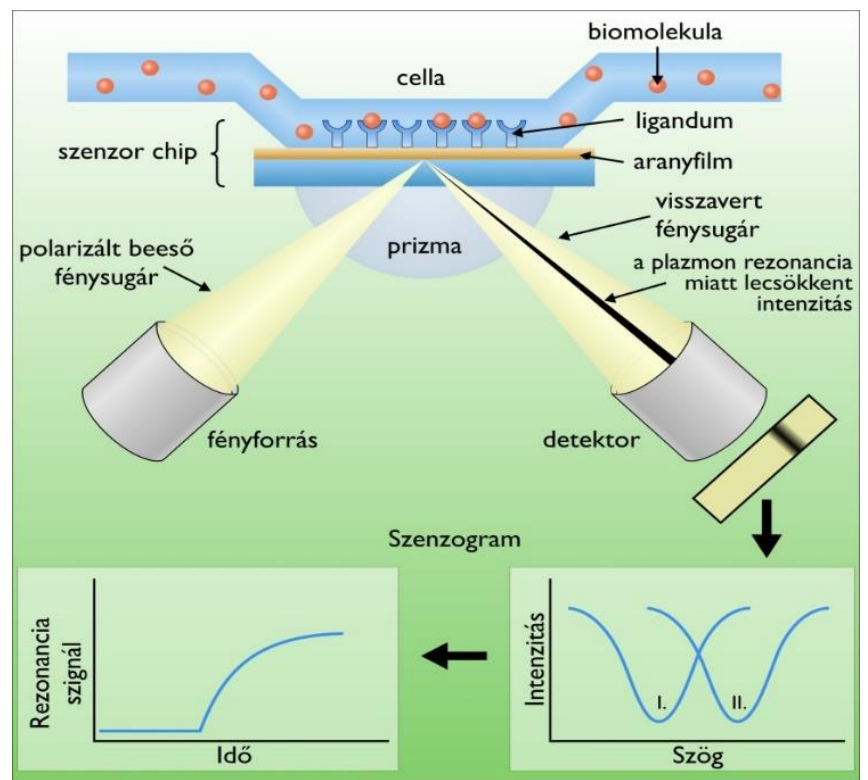

2. ábra: Felületi plazmon rezonancia mérési elve (Hegyi et al., 2013) 
Az SPR technikát a bioanalitikában az 1980-as évek elején Liedberg és mtsai $(1983,1995)$ alkalmazták először, immunglobulint adszorbeáltatva az ezüstréteget hordozó szenzorra, majd az immunglobulin ellen termeltetett antitest kötődését vizsgálták. Tüdős és mtsai (2003) búzából deoxynivalenol (DON) kimutatására alkalmas, SPR spektroszkópia alapú immunszenzort fejlesztettek ki. Kompetitív mérési módszert alkalmaztak, ahol kazein-DON konjugátum került rögzítésre. A mérés lineáris tartománya 2,5-30 ng/ml volt. A szenzor több mint ötszáz alkalommal volt újrahasználható jelentősebb aktivitásvesztés nélkül, 6 M-os guanidin-kloriddal történő regenerálással. Mullett és mtsai (1998) fuminozin $B_{1}$ kimutatására alkalmas SPR alapú direkt immunszenzort fejlesztettek ki $50 \mathrm{ng} / \mathrm{ml}$ kimutatási határral. A technika alkalmas volt a toxin egyszerü, gyors (10 perc/minta) kimutatására.

\section{Reflexiós interferencia spektroszkópia (RIfS)}

Reflexiós interferencia spektroszkópia technika a fehér fénynek az eltérö törésmutatójú rétegek határfelületéről történő többszörös visszaverődésén alapszik. Általában egy vékony üveghordozón tipikusan $330 \mathrm{~nm}$ vastagságú magasabb törésmutatójú réteget alakítanak ki (interference layer), melyet, ha halogén lámpából származó fehér fénnyel világítunk meg, a fény minden fázishatárnál részben visszaverődik. A visszaverődött sugarak interferálnak. $\mathrm{Az}$ interferencia függ a két határfelület közti távolságtól és a hullámhossztól. Ha a szenzor felületére molekulák kötődnek, akkor növekszik a rétegvastagság, ugyanakkor a két határfelület közötti távolság is, ami az interferenciaspektrum nagyobb hullámhossz felé történő eltolódását okozza. Az interferencia spektrum folyamatos felvétele diódákkal történik, mely spektrumból számítható az optikai denzitásban bekövetkezett változás az idő függvényében (Schmitt et al., 1997). A mérés során meghatározható, vizsgálati módszertől függően, a vizsgált anyag koncentrációja, valamint termodinamikai és kinetikus állandók. Az SPR-rel szemben, itt szenzorfelületként nem csak fémes felületek alkalmazhatók, hanem $\mathrm{SiO}_{2}$ (szilícium-dioxid), ITO (indium ón-oxid), $\mathrm{TiO}_{2}$ (titándioxid), még mủanyag, úgynevezett TOPAS (cikloolefin kopolimer) felületek is (Pröll et al., 2005).

\section{Ellipszometria}

Az ellipszometria működésének lényege, hogy eltérő határfelületeken a különböző polarizációjú (beesési síkkal párhuzamos vagy arra merőleges rezgési síkú) fény visszaverődése során a térerővektor amplitúdója és fázisa is megváltozik. Ez a változás eltér a beesési síkkal párhuzamosan és arra merőlegesen polarizált komponensekre, amelyek között fáziskülönbség lép fel. A fáziskülönbség függ a felületen lévő réteg vastagságától és törésmutatójától (Garipcan et al., 2011). 
Napjainkban az egyik leggyakrabban használt ellipszometriás immunszenzor a teljes belső visszaverődéses ellipszometria (TIRE). Nabok és mtsai (2011) aflatoxin $\mathrm{B}_{1}$ kimutatására alkalmas TIRE- immunszenzort fejlesztettek ki mintegy 0,04 ng/ml-es kimutatási határral. T-2 mikotoxin (insariotoxin) kimutatására szintén sikeresen alakítottak ki immunszenzort, mellyel jóval alacsonyabb kimutatási határt tudtak elérni, mint QCM (kvarckristály mikromérleg) vagy SPR alkalmazásával (Nabok et al., 2005, Nabok et al., 2007).

\section{Interferometria}

Az interferométerek müködési elve, hogy a rendszerébe jutó fényt két egymástól független útvonalon juttatja el a detektorig, ahol azokat interferáltatva a két nyaláb (mérő és referencia ágak) fáziskülönbségéről kapunk információt. Interferometria alapú, jelölésmentes bioérzékelésre alkalmas eszközök közül a legismertebbek a Mach-Zender interferométer (MZI) alapú eljárások. A müszer müködésének alapja, hogy a mérö águkban haladó fény a mintán halad át, miközben a referenciaágban haladóhoz képest fáziseltolódást szenved. Amennyiben az oldat optikai sürüsége változik, a detektált interferencia intenzitás is ezzel arányosan módosul (Sepúlveda et al., 2006). MZI technika immunszenzorként való alkalmazhatóságát számos kutatócsoport bizonyította (Lechuga et al., 1995, Schipper et al., 1997, Heideman et al., 1993).

\subsubsection{Piezoelektromos immunszenzorok}

\subsubsection{Kvarckristály mikromérleg (QCM)}

A kvarckristály mikromérleg (QCM) egy rendkívül érzékeny, piezoelektromos effektus alapján működő tömegmérő rendszer. A kvarckristály érzékelő, mely mindkét oldalán arannyal bevont, váltóárammal magas frekvenciájú rezgésbe hozható. A kristály oszcillációs frekvenciáját a felületre rakódó anyagok megváltoztatják, és ezt a frekvenciaváltozást detektáljuk. Ha molekulák kötődnek a kvarckrisrály felületére, akkor növekszik a tömege és a rezonancia frekvenciája csökken. A mérések során már $0,1 \mathrm{ng} / \mathrm{cm}^{2}$-nél kisebb tömegváltozásnak megfelelő frekvenciaváltozás is mérhető (Sauerbrey, 1959, Tuantranont et al., 2011). A QCM technika olcsó, használata egyszerü, nagy érzékenységü és valósidejü, jelölésmentes vizsgálatra alkalmas ezért az immunszenzor fejlesztésben igen elterjedt technika.

A legújabb kutatások az úgynevezett mágneses QCM (magnetic QCM) technikák felé irányulnak, ahol mágneses nanorészecskék felhasználásával a kimutatási határ csökkenthető. Wang és mtsai (2009) aflatoxin $B_{1}$ kimutatására készített immunszenzorukban a szenzor felületén aflatoxin $\mathrm{B}_{1}$ ellen termelt antitestekkel funkcionalizált mágneses nanorészecskéket rögzítettek. Az így kialakított szenzor lineáris mérési tartománya 0,3-7 ng/ml közt volt. Az immunérzékenyített mágneses részecskéket az érzékelő felület alatt elhelyezett elektromágnes vonzza, illetve rögzíti a 
szenzorfelszínhez (Bruls et al., 2009). Li és mtsai (2011) H5N1 influenza vírus kimutatására fejlesztettek ki QCM alapú immunszenzort, ahol a szenzor felületére poliklonális antitestet rögzítettek. A mintában lévő H5N1 vírus antitesthez való kötődése frekvenciaváltozást idéz elő a szenzoron, mely jelet tovább erősítettek H5N1 ellen termelt antitestekkel borított 30 nm-es mágneses nanogyöngyök hozzáadásával.

\subsubsection{Mikro-és nanomechanikus erökarok (mikrokonzolok)}

A mikrokonzol szenzorok a mechanikus erőkarok megfelelő kémiai érzékenyítéssel kialakított változatai. A mikrokonzolok tipikusan 0,2-1 $\mu \mathrm{m}$ vastag, 20-100 $\mu \mathrm{m}$ széles és 100-500 $\mu \mathrm{m}$ hosszú rugalmas lapkák, amelynek egyik vége egy szilárd tartóhoz van rögzítve. A mérés során a mikrokonzol elhajlásának mértéke, vagy a rezonanciafrekvencia változása detektálható. Ennek alapján megkülönböztethetünk statikus és dinamikus mikrokonzol szenzorokat. A mikrokonzol elhajlását a lapka végére irányított lézersugár visszaverődésén keresztül detektálható. Dinamikus üzemmódban a mikrokonzolok mikromechanikai oszcillátorokként működnek és a mikrokonzol tömegváltozása a rezonanciafrekvencia változásán keresztül határozható meg. Ha a felülethez molekulák kötődnek az megváltoztatja a mikrokonzol tömegét és ez a tömegváltozás valós időben nyomonkövethető a rezonanciafrekvencia változásán keresztül (Gyurcsányi, 2005). Mivel a mikrokonzolok könnyen tömbbe rendezhetök, velük nagyszámú párhuzamos mérés végezhető. Campbell és mtsai (2007) Staphylococcus aureus által termelt enterotoxin B kimutatására mechanikus erőkar alapú szenzort alkalmaztak. A konzol aminocsoportokkal módosított felszínére rögzítették az enterotoxin B ellen termelt poliklonális antitestet, majd a toxint tartalmazó mintát 1 $\mathrm{ml} /$ perc sebességgel áramoltatták a szenzor felületén. A kialakított szenzor mérési tartománya 12,5 $\mathrm{pg} / \mathrm{ml}$ és $50 \mathrm{pg} / \mathrm{ml}$ közt volt.

\subsection{Optikai hullámvezető fénymódus spektroszkópia technika elvi alapjai}

Az optikai hullámvezető fénymódus spektroszkópia technika az 1980-as évek végén alakult ki a többi felületi adszorpciós eljáráshoz hasonlóan. Az OWLS technika alkalmas az optikai hullámvezető felületén, molekuláris szinten végbemenő, affinitáson alapuló folyamatok valósidejü, jelölésmentes vizsgálatára.

\subsubsection{OWLS müködési elve}

Az optikai hullámvezetés jelenségét felhasználó technika alkalmazásának alapja egy integrált optikai hullámvezető szenzor, röviden chip, amely két eltérö törésmutatójú rétegből áll: egy 0,5 mm vastag kisebb törésmutatójú üveghordozóból $(n=1,57)$ és az erre felvitt vékony $(160-$ 
$220 \mathrm{~nm})$ nagy törésmutatójú hullámvezető rétegből $(\mathrm{n}=1,7 \pm 0,3)$. Ezen a hullámvezető rétegen finom optikai rácsot (2400-3600 vonal/mm sürüségü) alakítanak ki, aminek segítségével lehet a lineárisan polarizált He-Ne $(632,8 \mathrm{~nm})$ lézer fényt a hullámvezető rétegbe becsatolni. Az integrált optikai hullámvezető szenzor szerkezetét a 3. ábra mutatja be.

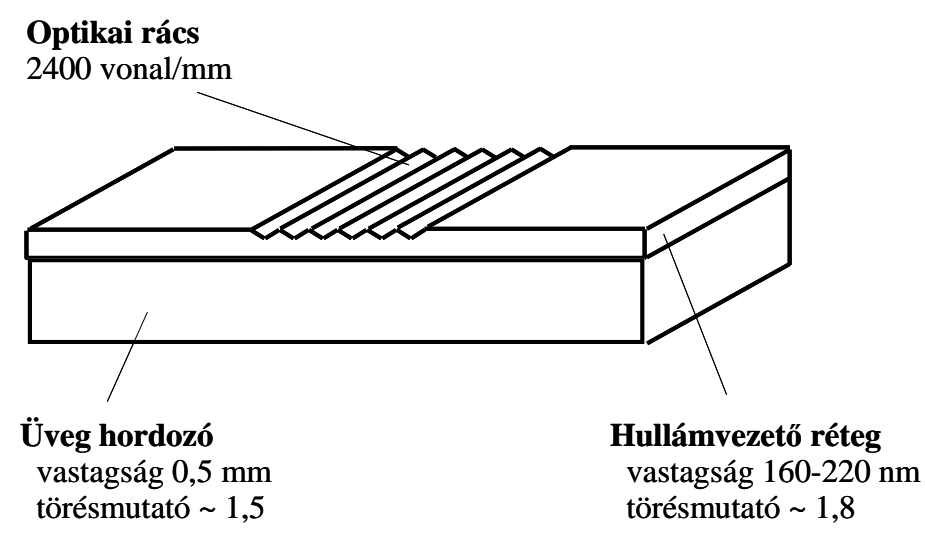

3. ábra Integrált optikai hullámvezető szenzor felépítése (OW2400, MikroVákuum Kft.)

A becsatolás egy pontosan definiált beesési szögnél lejátszódó rezonancia jelenség, amely függ a hullámvezető, valamint a hullámvezető felületén lévő anyag törésmutatójától. A becsatolt fény a hullámvezetőben teljes visszaverődések sorozatával terjed, és a hullámvezető végén elhelyezett fotodiódákkal detektálható (4. ábra).

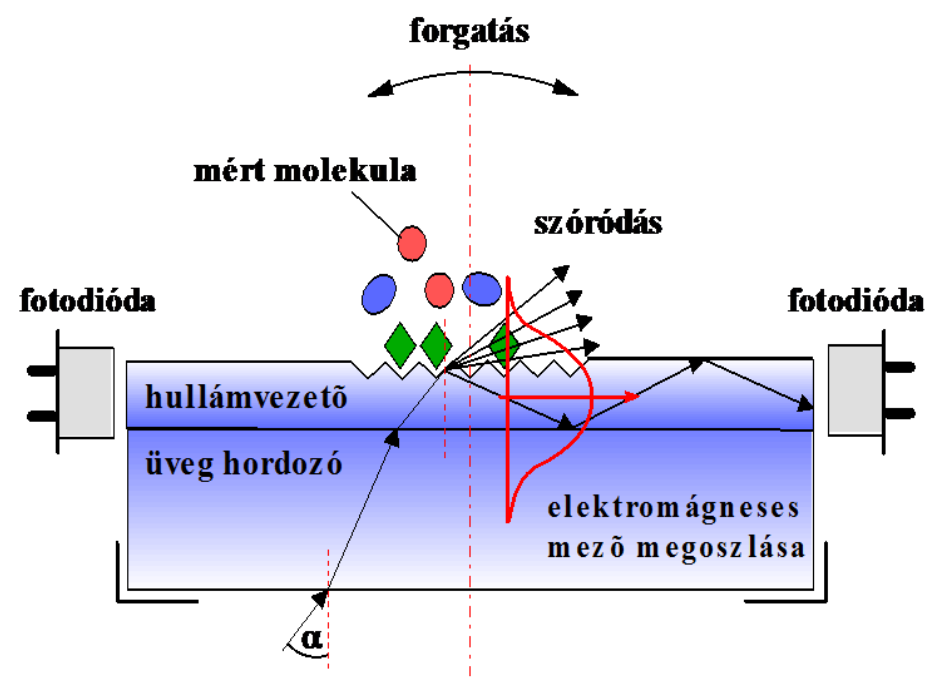

He-Ne lézer sugár

4. ábra Az otikai hullámvezető fénymódus spektroszkópia müködési elve 
A becsatolási szögek ismeretében, a négyrétegü hullámvezető linearizált módusegyenlete segítségével (amikor a felületen adszorbeált réteg is jelen van), a hullámvezetőre abszorbeálódott anyag törésmutatója $\left(\mathrm{n}_{\mathrm{A}}\right)$ és rétegvastagsága $\left(\mathrm{d}_{\mathrm{A}}\right)$ kiszámítható. E két paraméter ismeretében a Feijter képlet (De Feijter et al., 1978) felhasználásával pedig az egységnyi felületre abszorbeálódott tömeget $(\mathrm{M})$ kaphatjuk meg.

$$
M=d_{A} \frac{n_{A}-n_{C}}{d n / d c}
$$

A $d n / d c$ a felületre abszorbeálódott anyag törésmutatójának koncentrációtól való függésére jellemző, és értéke fehérjék többségére univerzális és állandó $\left(0,182 \mathrm{~cm}^{3} / \mathrm{g}\right)$ (Vörös et al., 2002).

\subsubsection{Hordozó jellemzése}

A hullámvezető réteg egy speciális üvegréteg melynek törésmutatója nagyobb $(n=1,6-2,2)$ az üveghordózóénál $(n=1,5)$ és rétegvastagsága $(160-220 \mathrm{~nm})$ kis ingadozást $(5-10 \%)$ mutat. A hullámvezető hordozójaként általában bórszilikát üveget alkalmaznak, melynek magas a $\mathrm{BaO}$ (bárium-oxid) és $\mathrm{Al}_{2} \mathrm{O}_{3}$ (alumínium-oxid) tartalma, alkálimentes, szintetikus anyag.

A hullámvezető anyaga $\mathrm{SiO}_{2}-\mathrm{TiO}_{2} 75 \%-25 \%$ arányú keverékéből áll, de a $\mathrm{TiO}_{2}$ mennyiség akár a 40\%-ot is elérheti. A szervetlen $\mathrm{SiO}_{2}-\mathrm{TiO}_{2}$ hordozóként történő alkalmazása számos előnyt jelent a szerves hordozókkal szemben, elsősorban fizikai tulajdonságai alapján. A szervetlen hordozók nagyobb mechanikai ellenállóképessége, hőstabilitása, szerves oldószerekkel, ill. mikrobákkal szembeni ellenállóképessége, egyszerübb regenerálhatósága, hosszú élettartama alkalmasabbá teszi az ipari felhasználásra. A szenzor felületén szilanol $(\mathrm{SiOH})$ ill. titanol csoportok találhatók, melynek mennyisége a $\mathrm{SiO}_{2}-\mathrm{TiO}_{2}$ arányától, illetve a hullámvezető réteg kialakításánál használt hőmérséklettől függ. Minél nagyobb a $\mathrm{TiO}_{2}$ aránya annál jobban nedvesíthető a felület. Minél magasabb a hullámvezető réteg kialakításánál használt hőmérséklet annál hidrofóbbá válik a felület, annál nehezebb a rehidratáció. Weetall és Filbert (1974) kisérlete alapján egy $\mathrm{SiO}_{2}$ felületen $5,3 \mathrm{db} \mathrm{SiOH}$ csoport $/ \mu \mathrm{m}^{2}$ volt található, mely $400{ }^{\circ} \mathrm{C}$-os kezelést követően 2,6 db SiOH csoport/ $\mu \mathrm{m}^{2}$-re csökkent, $850{ }^{\circ} \mathrm{C}$-os kezelést követően pedig kevesebb, mint

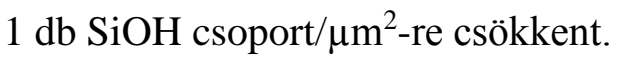

\subsubsection{Hordozó felületének módosítása}

A hullámvezető felülete hidrofób, erősen dehidratált, a rajta lévő -OH csoportok kevés lehetőséget biztosítanak a biomolekulák kovalens rögzítésére, ezért a szenzor felületét módosítani kell. A felületmódosításra leggyakrabban alkalmazott eljárás a szilanizálás. Az eljárás célja, hogy könnyebben tudjunk kialakítani a hordozó és a biomolekula között kovalens kötést. E mellett a 
szilanizálás csökkenti a nem specifikus adszorpciót, ellenállóbbá teszi a felületet a külső hatásokkal szemben, pl.: a lúgokkal szembeni érzékenység csökken.

A szilanizálási folyamat megkezdése elött a hordozót meg kell tisztítani minden szennyeződéstől. A felülettisztítás lehet igen egyszerü vagy többlépcsős bonyolult fizikai (hőkezelés, ultrahang vagy $\mathrm{O}_{2}$ plazma kezelés), vagy kémiai (savak és lúgok) eljárás. A legegyszerübb módszer a hőkezelés, mely során a hordozót nagyon magas hőmérsékletre hevítik, így távolítva el az esetleges szerves szennyeződéseket. Általában a fent említett módszerek kombinációját alkalmazzák (Cras et al., 1999). A tisztítás és hidratálás történhet 5\%-os salétromsav oldatban való 45 perces forralással, majd ezt követően desztillált vizes mosással, illetve $80-90^{\circ} \mathrm{C}$-os salétromsavban történő (0,75-4 óra) melegítéssel (Williamson et al., 1989, Weetal, 1993, Williams és Blanch, 1994). A felület tisztítható lúgokkal és detergensekkel (Deconex) is (Clerc és Lukosz, 1997).

\subsubsection{Szilanizálás}

A fém-oxid felületek módosítására használt szilánok általános képlete: $\mathrm{R}_{\mathrm{n}} \mathrm{Si} \mathrm{X}_{(4-\mathrm{n})}$, ahol az R egy olyan nem hidrolizálható funkciós csoport, amely a rögzítendö molekulával közvetlenül, vagy keresztkötő vegyületek segítségével közvetetten tud kapcsolódni. Az X egy hidrolizálható csoport, amely lehet alkoxi-, amino- vagy klorocsoport. Az X csoport vesz részt a szilán és a hordozó között kialakuló sziloxán kötésben. A leggyakrabban alkalmazott alkoxicsoportok a metoxi- és etoxi- csoportok, melyek a kötés kialakulásakor melléktermékként metanolt és etanolt képeznek. A kloroszilánok alkalmazásánál melléktermékként sósav keletkezik, ezért felhasználásuk jóval szükebb körü. A kötési folyamat négy lépésben játszódik le:

$>$ Először megtörténik az X csoport hidrolízise, melynek során reaktív szilanol csoport keletkezik. A hidrolízishez szükséges víz számos forrásból származhat. Lehet hozzáadott víz, de a felületen jelenlevő víz is betöltheti e szerepet, vagy az atmoszférából, illetőleg a felhasznált oldószerből is származhat.

$>$ Ezt követően a szilánmolekulák oligomerekké kapcsolódnak.

$>$ A harmadik lépésben az oligomerek a hordozó hidroxil csoportjához hidrogénkötésekkel kapcsolódnak.

> Végül pedig egy szárítási folyamat következik, melynek során vízkilépés kíséretében kialakul a hordozó és a szilán közt a kovalens kötés.

A felületmódosításhoz alkalmazott szilán típusát elsősorban a biológiailag aktív molekula szerkezete, illetve az alkalmazott rögzítési módszer alapján határozzuk meg. A fentiekből is 
látszik, hogy a kötés tulajdonságait nagymértékben befolyásolja, hogy az adott szilánmolekula hány hidrolizálható csoportot tartalmaz. Leggyakrabban három hidrolizálható csoportot tartalmazó szilánmolekulákat szoktak alkalmazni. E szilánmolekulák a hidrolizálható csoportok hidrolízise révén, többszörösen összekapcsolódnak, és egy háromdimenziós erősen keresztkötött hálózatot hoznak létre, így kapcsolódva a hordozóhoz, multimolekuláris réteget alkotva (Wang et al., 1994). A trifunkciós szilánok merev felületet, de maximális hidrolitikus stabilitást biztosítanak. A bifunkciós szilánokkal kevésbé rigid felület hozható létre, mint a trifunkciós szilánok alkalmazásával. Az egy funkciós csoportot tartalmazó szilánok monomolekuláris réteget képeznek, erősen hidrofób felületet adnak és hidrolitikus stabilitásuk kicsi.

A kialakított szilánréteg vastagságát az alkalmazott szilán típusa határozza meg, azonban az oldószer, az oldat koncentrációja és víztartalma, de az alkalmazott hőmérséklet és időtartam is befolyásolja (Bier és Schmid, 1994, Spinke et al., 1997).

A szilánvegyület oldásához használt oldószert tekintve a szilanizálás vizes és szerves fázisban történhet. Vizes fázisban történő szilanizálás esetén a kezelni kívánt anyagot a szilán vizes oldatában áztatják. Ezzel az eljárással vékony, egyenletes szilánréteg hozható létre, habár kevesebb funkciós csoport alakítható ki, mint szerves szilanizálással, ugyanakkor a kapott hordozó sokkal stabilabb. Szerves szilanizálásnál a szilánt illékony, illetve kevésbé illékony oldószerben oldják. Illékony oldószer alkalmazásánál a felületen a szilánoldatot kíméletesen bepárolják, az oldószert alacsony hőmérsékleten elpárologtatják. Kevésbé illékony oldószert alkalmazva a hordozót az oldatba történő bemerítéssel szilanizálják. Így vastagabb nagyobb kapacitású szilánréteget lehet kialakítani, bár a réteg felületen történő eloszlása nem teljesen egyenletes.

\subsubsection{Biomolekulák rögzítésének lehetőségei a szenzorfelületen}

A biomolekulák számos reaktív csoporttal rendelkeznek, melyek alkalmasak kovalenskötés kialakítására. Ezek közül leggyakrabban az amino-, szulfhidril-, karboxil- és aromás csoportokat használjuk. A biomolekulák hullámvezetőn történő kovalens rögzítéséhez a szenzor felületét a rögzítést megelőzően egy vagy több lépésben aktiválni kell, azaz rajta olyan reaktív funkciós csoportokat kell kialakítani, amelyekhez a fehérjék már közvetlenül, egy lépésben köthetők. A szilanizálással módosított szenzor felületén történő biomolekulák rögzítésének különböző lehetőségeit az 5. ábra mutatja be. 


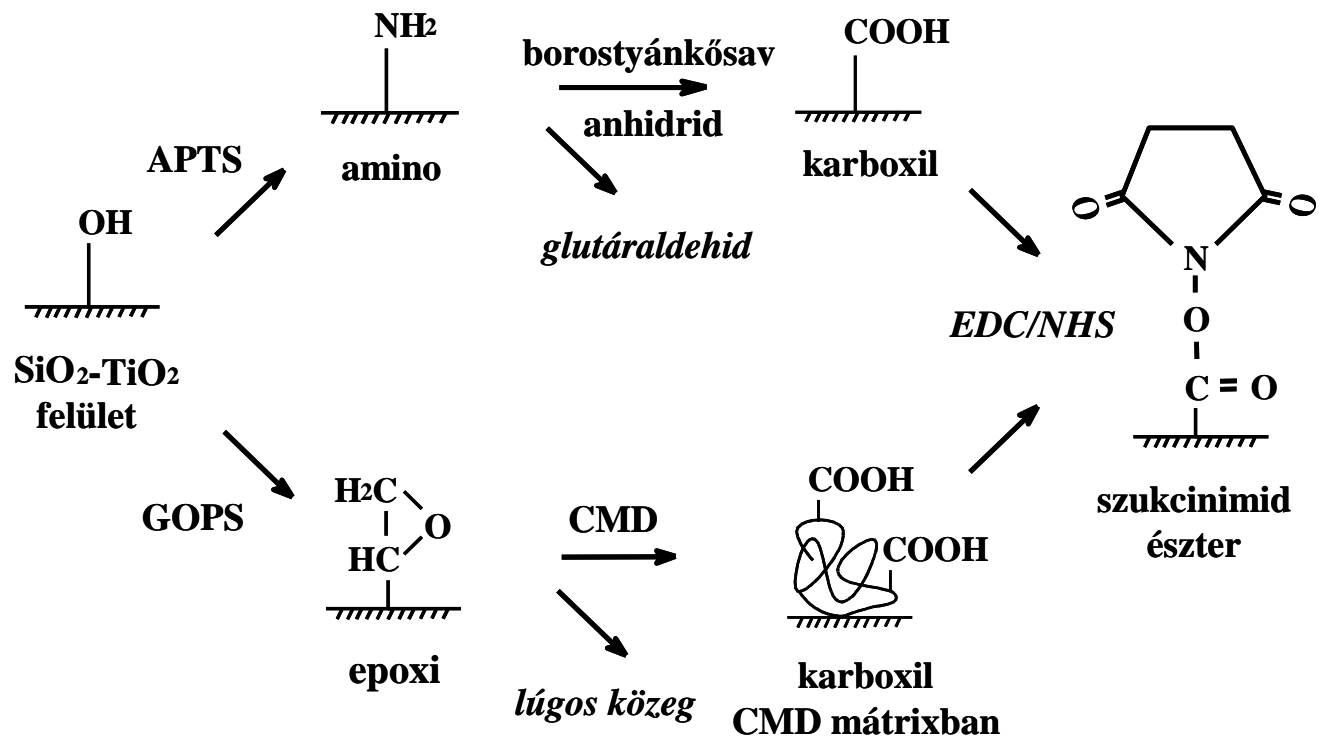

5. ábra Biomolekulák rögzítésének lehetőségei a szenzorfelületen (Adányi, 2014)

Az APTS-sel módosított szenzorfelületen a biomolekulák rögzítése történhet rövid bifunkciós keresztkötő vegyületekkel (glutáraldehid), vagy más egyéb reaktív csoportok kialakítására alkalmas vegyületekkel (1-etil-3-(3-dimetil-amino-propil)-karbodiimid (EDC) és Nhidroxi-szukcinimid (NHS)) (Hunt et al., 2010). A glutáraldehid egy olyan kis bifunkciós molekula, amely a molekula két végén található aldehidcsoporttal két aminocsoport összekapcsolására alkalmas. A keresztkötő vegyület a hordozó aminocsoportjait és a fehérje aminocsoportjait hídként kapcsolja össze.

A másik lehetőség, hogy az APTS reagenssel kezelt szenzorfelületek aminocsoportjait borostyánkősavanhidrides kezeléssel karboxilcsoportokká alakítjuk, melyhez EDC/NHS technikával a biomolekulák a hordozóhoz rögzíthetők. Az EDC egy amino- és karboxilcsoportok összekapcsolására alkalmas karbodiimid, mely az aktiválás során az NHS karboxilcsoporthoz való kötődését teszi lehetővé. Az NHS kötődésével a fehérjék aminocsoportjai számára könnyen támadható szukcinimid észter alakul ki, ami a rögzítés során lehasad a hordozóról és a fehérje közvetlen a karboxilcsoporthoz kapcsolódik.

A $\gamma$-glicidoxi-propil-trimetoxi-szilánnal (GOPS) kezelt, epoxicsoportokat tartalmazó felületek nem igényelnek külön aktiválást, rajtuk a fehérjék lúgos közegben közvetlenül rögzíthetők, vagy karboxi-metil-dextránt (CMD) rögzítve a szenzoron, a kialakított dextránmátrixban az EDC/NHS eljárással rögzíthetőek a biomolekulák. 


\subsection{Deoxynivalenol}

Az élelmiszerek mikotoxin szennyezettsége az egész világon súlyos élelmiszerbiztonsági problémát jelent. Európában elsősorban a Fusarium penészgombák által okozott fertőzések jelentik a fó veszélyt. A gombák jelenléte az élelmiszerek, illetve élelmiszer-nyersanyagok minőségét hátrányosan befolyásolja, hiszen jelentős szerepük van az élelmiszerek érzékszervi tulajdonságainak romlásában, tápértékének csökkenésében és az általuk termelt mikotoxinok egészségkárosító hatásában. A deoxynivalenol (DON) a takarmánynövényekben, gabonákban az egyik leggyakrabban előforduló mikotoxin. Ahhoz, hogy az élelmiszerek DON tartalmát meghatározzuk megbízható, olcsó, gyors, egyszerü analitikai módszerek szükségesek. Az eddigi hagyományos mérési módszerek HPLC, GC-MS megbízhatóak, de igen költséges és bonyolult eljárások, ezért szükséges olyan technikák kidolgozása, amelyek lehetővé teszik a DON gyors kimutatását, ugyanakkor megfelelően szelektívek és érzékenyek.

\subsubsection{Trichotecének}

A mikotoxinok szekunder metabolitok, amiket leggyakrabban penészgombák termelnek. Ezek a vegyületek nem szükségesek a gomba növekedéséhez vagy szaporodásához, de az állatokra és emberekre nézve igen veszélyes, mérgező anyagok. Egy gombafaj akár többféle mikotoxint is termelhet, ugyanakkor egy adott toxint többféle gomba fertőzésére is utalhat. Eddig több mint háromszáz különböző mikotoxint fedeztek fel, ismertek meg, de a természetben a számuk valószínű ennél jóval nagyobb. Számos jelentés szerint évente a learatott gabonák, iparnövények kb. 25-50\%-a fertőzött mikotoxinokkal (Ricciardi et al., 2013). Az elmúlt évtizedekben a fuzáriumos csőpenészedés jelentette a legsúlyosabb, penészek által okozott megbetegedést a kukoricatermesztésben, mely az egész világon hatalmas gazdasági veszteséget okoz (Osborne és Stein, 2007). A Kárpát-medencében elsősorban a Fusarium graminearum által okozott fertőzések kerültek elötérbe, amely a klímaváltozás hatásainak és az ipari mezőgazdasági gyakorlat következményeinek tudható be.

A mikotoxinok legnagyobb csoportját a trichotecének alkotják, melyeket elsősorban Fusarium, Stachybotrys, Myrothecium és egyéb szaprofita gombák termelnek. A trichotecének kémiailag szeszkviterpén vázú vegyületek. Ez több mint 50 kémiailag rokon vegyületet jelent. Minden, a trichotecénvázas fusariotoxinok csoportjába tartozó, természetben előforduló mikotoxin tartalmaz egy 15 szénatomból álló lánchoz hapcsolódó epoxid gyürüt, egy telítettlen kötést a 9. és a 10. szénatom között és egy epoxi gyököt a 12. és a 13. szénatomnál. Ez utóbbi alapján nevezik ezeket a vegyületeket 12,13-epoxitrichotecéneknek (ApSimon et al., 1990). A trichotecénvázas mikotoxinok toxicitásának kémiai alapját a 12,13-epoxid gyürü, és azon hidroxil 
és acetil oldalláncok adják, melyek ehhez a gyürühöz kötődnek. Számos e csoportba tartozó mikotoxin kettős kötést is tartalmaz a 9. és 10. szénatomja között, amely nagymértékben befolyásolja az adott mikotoxin toxicitását. Előfordulnak olyan Fusarium fajok is, amelyek egy adott mikotoxin acetilált, illetve nem-acetilált formáját is képesek termelni, ami szintén toxicitást befolyásoló tényező.

A trichotecének kémiai struktúrájuk alapján „A”, „B”, „C” és „D” alcsoportba sorolhatók (Ueno, 1977). Az „A”, „B”, „C” típusú trichotecének a 8. szénatomon lévő funkciós csoportok alapján különböztethetők meg. Az „A” trichotecének a 8. szénatomon hidroxilcsoportot tartalmaznak, mint pl. a neoszolaniol esetén, vagy észter kötést, mint a T-2 toxin esetén. Az „A” trichotecének domináns termelője a $F$. sporotrichoides és az esetlegesen toxintermelő $F$. poae. A négy csoport közül ez a legnagyobb, amely magában foglalja a T-2 toxinokat, és a HT-2 toxinokat, illetve a diacetoxi-szcirpenolt (DAS) és a neoszolaniolt (NEO). A „B” csoport tagjai (DON, Nivalenol, Fusareon-X) a 8. szénatomon ketocsoportot tartalmaznak. A „B” csoport esetében a két domináns toxintermelő gombafaj a $F$. culmorum és a $F$. graminearum. A $F$. graminearum esetében a fajon belül két típust különítenek el, amelyek közül az egyik DON-t, a másik pedig nivalenolt (NIV) termel (Perkowski et al.,1997). A „C” csoport szerkezete abban különbözik az előző csoportoktól, hogy a 7., 8. szénatomokhoz egy második epoxid gyürü is kapcsolódik, a „D” csoport trichotecénjei pedig a 4. és a 15. szénatom között kettős észterkötéssel kapcsolva egy makrociklusos gyürüt tartalmaznak. A leggyakrabban előforduló B trichotecéneket, mint a deoxynivalenol, nivalenol, 3-acetil-deoxynivalenol, 15-acetil-deoxynivalenol, valamint a fusarenon X-et mutatja be a 6 . ábra.

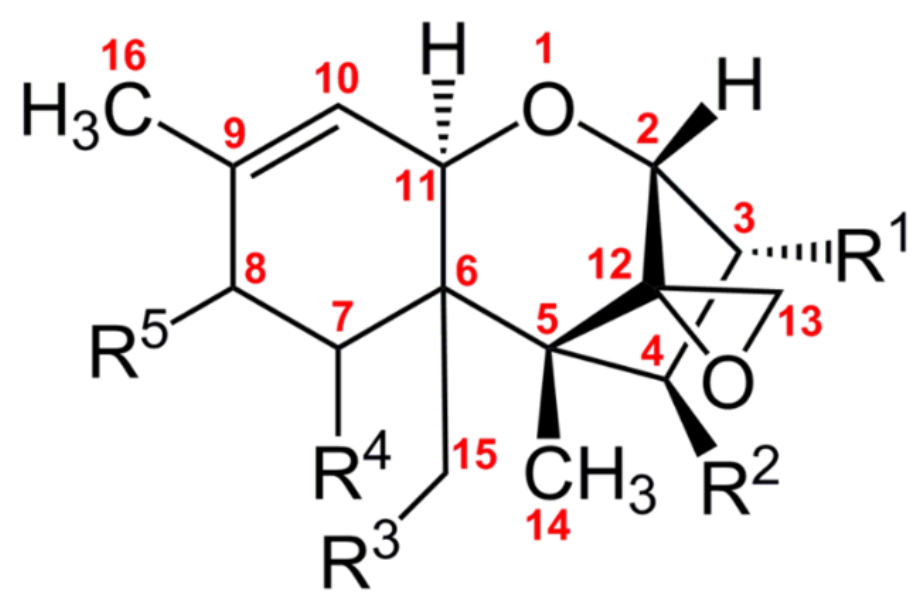

6. ábra A „,B” trichotecének szerkezete

(Deoxynivalenol $-\mathrm{R}_{1}=\mathrm{OH}, \mathrm{R}_{2}=\mathrm{H}, \mathrm{R}_{3}=\mathrm{OH}, \mathrm{R}_{4}=\mathrm{OH}, \mathrm{R}_{5}=\mathrm{O}=$; Nivalenol $-\mathrm{R}_{1}=\mathrm{OH}, \mathrm{R}_{2}=$ $\mathrm{OH}, \mathrm{R}_{3}=\mathrm{OH}, \mathrm{R}_{4}=\mathrm{OH}, \mathrm{R}_{5}=\mathrm{O}=$; 3-acetil-deoxynivalenol - $\mathrm{R}_{1}=\mathrm{OAc}, \mathrm{R}_{2}=\mathrm{H}, \mathrm{R}_{3}=\mathrm{OH}, \mathrm{R}_{4}=$ $\mathrm{OH}, \mathrm{R}_{5}=\mathrm{O}=$; 15-acetil-deoxynivalenol $-\mathrm{R}_{1}=\mathrm{OH}, \mathrm{R}_{2}=\mathrm{H}, \mathrm{R}_{3}=\mathrm{OAc}, \mathrm{R}_{4}=\mathrm{OH}, \mathrm{R}_{5}=\mathrm{O}=$; Fusarenon $\mathrm{X}-\mathrm{R}_{1}=\mathrm{OH}, \mathrm{R}_{2}=\mathrm{OAc}, \mathrm{R}_{3}=\mathrm{OH}, \mathrm{R}_{4}=\mathrm{OH}, \mathrm{R}_{5}=\mathrm{O}=$ ) 


\subsubsection{A DON-toxin jellemzése}

A trichotecén mikotoxinok közül a mérsékelt égövi országokban -irodalmi adatok alapjánleggyakrabban a DON mikotoxin szennyezettség fordul elő (Scott, 1989; Placinta et al., 1999; WHO/FAO, 2000). A DON-t, más néven vomitoxint, de ismert dehidro-nivalenolként vagy RDtoxinként is, először Japánban az 1970-es években izolálták és jellemezték Fusarium gombával fertőzött árpából. DON mikotoxin fertőzöttség általában a búza, árpa, zab, rozs és kukoricára jellemző. Rizsben, cirokban és tritikáléban ritkábban található meg. A vomitoxin jelenlétét leginkább a Fusarium graminearum (Gibberella zeae) és a Fusarium culmorum gombák jelenlétével kapcsolják össze (Sobrova et al., 2010). A Fusarium gomba fertőzés következtében kiég a búza felső része, a Gibberella esetében pedig elkezd rothadni a kukorica kalásza. Kimutatták, hogy közvetlen kapcsolat van a kalász fuzáriumos kiégése és a vomitoxin mért szintje között. A Fusarium graminearum legjobban $25^{\circ} \mathrm{C}$-on és 0,88 -os vízaktivitási szint fölött szaporodik el. A Fusarium culmorum legjobban $21^{\circ} \mathrm{C}$-os környezetben 0,87 -os vízaktivitás fölött fejti ki hatását. A két faj földrajzi elterjedését leginkább a hőmérséklet határozza meg. A $F$. graminearum a gyakrabban előforduló faj, ami főként a melegebb égtájakon található meg (Canady et al., 2001).

Az élelmiszerek mikotoxin szennyezettsége az egész világon súlyos élelmiszerbiztonsági kockázatot jelent. A DON toxicitása más gabonákban és a takarmányban előforduló trichotecén mikotoxinokkal összehasonlítva enyhének mondható, csak néhány esetben jelentettek súlyos akut mérgezést. Mivel a DON az egyik leggyakrabban előforduló mikotoxin, ezért élelmiszerbiztonsági szempontból kiemelkedő fontosságú. Ember és állategészségügyi kockázatot a DON-nal fertőzött

élelmiszer illetve takarmány elfogyasztása jelenti. Általában krónikus toxikózisról beszélhetünk, melynek tünetei a csökkent élelembevitel és az ezzel együtt járó teljesítménycsökkenés, hányás, anorexia. A DON erős fehérjeszintézis gátló hatású, felborítja a citokinin szabályozást, megváltoztatja a sejt proliferációt és sejthalálhoz vezet. A fehérjeszintézis gátlása miatt az agy növeli a triptofán felvételét, s ennek következtében fokozódik a szerotonin szintézise. Az eddigi kutatási eredmények alapján feltételezhető, hogy a DON és más trichotecének a megnövekedett szerotoninszinten keresztül felelősek az anorexia kialakulásáért. Az is szerepet játszhat a csökkent élelembevitelben, hogy a vomitoxin irritálja az emésztő szervrendszert. Igen erős immunrendszer gátló (Rotter et al., 1996, Pestka, 2010). Vízben és poláros oldószerekben oldódik, mint a vízmetanol, víz-acetonitril, etil-acetát. A DON szerves oldószerekben stabil, leggyakrabban etilacetátban vagy acetonitrilben oldják. A toxin az élelmiszerekben illetve takarmányban stabil marad az alapvető feldolgozási és főzési folyamatok során is, ezért az alapanyagok szennyezettségének mértéke kulcskérdés. Számos országban ezért irányelveket és ajánlásokat 
fogalmaztak meg, mind a takarmány, mind az élelmiszer alapanyagok és a feldolgozott élelmiszerek DON tartalmának tekintetében. Az amerikai Élelmiszer- és Gyógyszerfelügyeleti Hatóság (FDA) ajánlásában az emberi fogyasztásra szánt feldolgozott búzatermékek DON tartalmát max. $1000 \mu \mathrm{g} / \mathrm{kg}$ szinten szabályozta, míg a takarmányokét $5000 \mu \mathrm{g} / \mathrm{kg}$-on. Az Európai Bizottság a DON élelmiszerekben megengedett maximális szintjét $200 \mu \mathrm{g} / \mathrm{kg}$-ban határozta meg a csecsemőknek, illetve a kisgyermekeknek szánt gabona alapú feldolgozott élelmiszerek esetén, $1750 \mu \mathrm{g} / \mathrm{kg}$ feldolgozatlan durumliszt, kukorica, zab esetén és $1250 \mu \mathrm{g} / \mathrm{kg}$-ban más feldolgozatlan gabona esetén, $700 \mu \mathrm{g} / \mathrm{kg}$ tésztáknál, $500 \mu \mathrm{g} / \mathrm{kg}$ kenyér és cereália alapú élelmiszerek esetén (Comission Regulation, 2006, EFSA, 2013).

\subsection{DON meghatározásra alkalmas analitikai módszerek}

Az utóbbi évtizedben a mikotoxinnal szennyezett gabonafélék előfordulásának száma folyamatos növekedést mutat, ezért mind gazdasági, mind állategészségügyi, mind élelmiszerbiztonsági szempontból különösen fontos olyan DON kimutatására alkalmas analitikai módszerek fejlesztése, amelyek megbízhatóak, használatuk egyszerü és olcsó. A mikotoxinok kémiai szerkezetének sokszínűsége, és az, hogy sokféle mátrixban találhatók meg, az analitikusok számára nagy kihívást jelentenek. A szelektivitás igénye mellett egyre nagyobb figyelmet kapnak az olyan technikák, amelyek megfelelően érzékenyek, hisz legtöbbször csak nyomokban található meg a toxin a mintában, így sokszor ppb vagy ppt szintü meghatározás szükséges. Legtöbbször ugyanazon mintában többféle mikotoxin van jelen, amelyek egymásra szinergista hatással lehetnek, ezért előtérbe kerültek azok a technikák, amik többféle mikotoxin egyidejü meghatározására alkalmasak (Pietro-Simon et al., 2007).

\subsubsection{Nagymüszeres analitikai technikák}

A DON kimutatására általánosan használt technikák nagy beruházást igénylő, nagymüszeres analitikai technikák, mint a nagy teljesítményü folyadék kromatográfia (HPLC) és gáz kromatográfia (GC), amit különböző detektorokkal kombinálnak, mint pl.: ultraviola-látható fény (UV-Vis) vagy fluoreszcens érzékelővel (FD), láng ionizációs detektorral (FID), elektronbefogási detektorral (ECD), tömeg spektroszkópiával (MS) vagy tandem MS-sel csatolnak (MS/MS).

A nagymüszeres technikákon belül a gázkromatográfiás módszerek alkalmazása a mikotoxin meghatározásban kiemelkedő volt. Scott és mtsai (1986) DON kimutatására használt gázkromatográfiás módszert ismertettek, mely módszer megbízható, ugyanakkor időigényes volt. Az analízisidőt a tisztítási lépés optimalizálásával próbálták lerövidíteni (Jiménez és Mateo, 1997). 
Onji és mtsai (1998) olyan GC-MS módszert mutattak be, amely nyolc különböző trichotecén meghatározására volt alkalmas a minta származékképzése nélkül. A vizsgálatban egy továbbfejlesztett hideg injektálásos módszert alkalmaztak. Cunha és Frenandes (2010) kifejlesztett egy QuEChERS (gyors, könnyü, olcsó, hatékony, robosztus és biztonságos) eljáráson nyugvó GCMS alapú új, validált analitikai eljárást DON és 15 -acetil-DON szimultán meghatározására. A kialakított módszerrel reggelizőpelyhek és lisztek mikotoxintartalmát vizsgálták. Reggelizőpelyhekben a kimutatási határ DON és 15 -acetil-DON esetén $11 \mu \mathrm{g} / \mathrm{kg}$ és $8 \mu \mathrm{g} / \mathrm{kg}$ volt, lisztben mindkét analitikum esetén $8 \mu \mathrm{g} / \mathrm{kg}$. Ibánez-Vea és mtsai (2011) A és B típusú trichotecének szimultán meghatározására alkalmas validált GC-MS módszert mutattak be, mely módszerrel árpa mikotoxin tartalmát határozták meg. Jakovac-Strajn és Tavčar-Kalcher (2012) szintén különböző gabonákból történő A és B típusú trichotecének szimultán meghatározására alkalmas validált GC-MS módszert ismertettek. Ma azonban egyre inkább a nagy teljesítményü folyadékkromatográfiás módszerek veszik át a mikotoxin meghatározásban a vezető szerepet, mert a maszkolt mikotoxin gázkromatográfiás módszerrel törénő meghatározása nehézkes, erőteljes származékképzési reakciókat kell alkalmazni, hisz a maszkolt mikotoxinok nagy része nem illékony vegyület.

Napjainkban a DON kimutatásra leggyakrabban alkalmazott módszer a különböző detektorokkal kombinált nagy teljesítményü folyadékkromatográfia. Klinglmayr és mtsai (2009) búza alapú élelmiszerek és takarmányok DON tartalmát vizsgálták HPLC-UV detektálással 220 nm-en. A DON kimutatási határa $200 \mu \mathrm{g} / \mathrm{kg}$ volt, míg a meghatározási határ $380 \mu \mathrm{g} / \mathrm{kg}$-nak adódott. Böhm és mtsai (2008) DON kukoricából történő meghatározását végezték HPLC-UV technikával, mely során a DON kimutatási határa $74 \mu \mathrm{g} / \mathrm{kg}$ volt. Egy másik kutatócsoport HPLCFD meghatározást használt DON kimutatására automatizált kétcsatornás oszlop utáni származékképzést alkalmazva. A detektálást 360 nm-en végezve a DON kimutatási határa durum búzából $14 \mu \mathrm{g} / \mathrm{kg}$ volt (Muscarella et al., 2012). A HPLC előnye a nagy érzékenység, ugyanakkor UV illetve FD detektálást alkalmazva a módszer nem kellően szelektív. Mikotoxinok kimutatására a HPLC-MS, illetve a HPLC-MS/MS módszerek a nagyfokú szelektivitásuk, nagy érzékenységük miatt a nyomnyi mennyiségek komplex mátrixokban történő meghatározásában az első számú módszerekké léptek elő az utóbbi évtizedben (Ran et al., 2013). Lattanzio és mtsai (2009) olyan LC-ESI-MS/MS technikát fejlesztettek ki, ami 11 különböző mikotoxin szimultán meghatározását teszi lehetővé, köztük DON, aflatoxin és ochratoxin A vizsgálatot kukorica mintákból. A minta előkészítés során tisztításához egy új típusú multi-toxin immunaffinitás oszlopot (Myco6in1, Vicam, USA) alkalmaztak, ami az összes vizsgálandó mikotoxin elleni specifikus antitestet tartalmazta. 
Annak ellenére, hogy az LC-MS/MS technikánál igen fontos szerepe van a mintaelökészítésnek, tisztításnak, a közelmúltban olyan LC-MS/MS technikát fejlesztettek ki mikotoxinok szimultán meghatározására, ami nem igényel minta tisztítást. A vizsgálatban kukorica és rizs minták mikotoxintartalmát (aflatoxin, ochratoxin, DON, fuminosin, zearalenon, T-2, HT-2 toxin) határozták meg. A mintákat acetonitril:víz:ecetsav 79:20:1 arányú keverékéből álló oldószeres extrakciót követően további tisztítás nélkül vizsgálták. A kimutatási határ 0,01-20 ng/g tartományban volt. (Soleimany et al., 2012).

Az LC-MS/MS technika alkalmazása a rejtett, maszkolt mikotoxintartalom (masked toxin) kimutatásában és mennyiségi meghatározásában is jelentős. Ezek a rejtett mikotoxinok az élelmiszerekben egy lényegesen polárosabb anyaggal (pl.: glükóz) konjugálódnak, így a rutin analitikai vizsgálatokkal nem kimutathatók, ugyanakkor az emésztőrendszerben hidrolízis útján felszabadulnak. Az LC-ESI-MS/MS analízisek alapján a leggyakoribb rejtett mikotoxin a deoxynivalenol-3-glükozid (DON-3-Glc), ami a szennyezett kukorica és búzaminták össz DON tartalmának a 12\%-át is jelentheti (Berthiller et al., 2005).

A fent ismertetett nagymüszeres technikák szelektívek és érzékenyek, de időigényesek, bonyolult mintaelőkészítést, minta tisztítást igényelnek. A minta tisztítására leggyakrabban szilárd fázisú extrakciót (SPE), immunaffinitás oszlopokat (IACs), multifunkciós oszlopokat alkalmaznak, de a molekuláris lenyomatú polimerek mintatisztításra való felhasználására is számos alkalmazást találhatunk az irodalomban. Többféle kereskedelmi forgalomban kapható SPE oszlop létezik, a töltetek rendkívül széles skálájával. Az SPE oszlopok trichotecének vizsgálatára történő alkalmazásánál figyelembe kell venni a technika hátrányait is, hiszen ezek a toxinok különböznek egymástól mind polaritásban, mind oldhatóságban, ezért néhányuk visszanyerése gondot okozhat. Ennek a problémának a leküzdésére számos kereskedelmi cég új tölteteket fejlesztett ki, mint pl. az Agilent Technologies Inc. létrehozta a Bond Elut Mycotoxin patront, ami 12 különböző A és B típusú trichotecén szimultán tisztítására alkalmas, beleértve a zearalenont is. Ezzel a technikával mind az analízisidő, mind az elemzés költségei csökkenthetők (Rahmani et al., 2009). Trichotecének tisztítására szintén gyakran alkalmazzák a multifunkciós oszlopok körébe tartozó MycoSep oszlopokat (Romer Lab Inc.). Az A és B típusú trichotecének tisztításához háromféle töltetű oszlop kapható, mely alkalmazása elsősorban a vizsgálati anyagtól függ (Langset et al., 1998, Krska et al., 2005). Ezen multifunkciós oszlopok alkalmazásával értékes analízisidőt lehet megtakarítani, hiszen nincs szükség az oszlop előkondicionálására és mosására.

Az immunaffinitás oszlopok (IACs) alkalmazása a mintatisztításban szintén igen elterjedt. Senyuva és mtsai (2010) publikáltak egy összefoglaló tanulmányt az IAC használatáról az élelmiszeranalízisben, beleértve a mikotoxinanalízist is. A technika legfőbb előnye az antitest és a kérdéses analitikum közötti specifikus kölcsönhatásban rejlik. Azonban, mint minden antitest 
alapú technikánál, a nem specifikus reakciók, amik a másféle trichotecénekkel való keresztreakciók miatt jönnek létre, az eredményeket ronthatják. A szerzők szerint az IAC alkalmazása a trichotecén analízisben rendkívül nagy jelentőségü. Egy hátránya van a technikának, mégpedig az a kereskedelmi forgalomban kapható oszlopok árában nyilvánul meg, hisz ezek igen drága, egyszerhasználatos oszlopok.

A mintatisztításnál a molekuláris lenyomatú polimerek (MIP) alkalmazása iránt egyre nagyobb érdeklődés mutatkozik. A MIP-ek olcsók, könnyen előállíthatók, nagy kémiai stabilitással és hosszú élettartammal rendelkeznek. DON meghatározására alkalmas MIP-ek szintézisét és karakterisztikáját Weiss és mtsai (2003) ismertették cikkükben.

\subsubsection{Gyors vizsgálati módszerek}

Az élelmiszerek és takarmányok mikotoxin monitorozásában nagyon fontos analitikai eszközök a gyors ellenőrzési (screening) technikák. Ezek általában minőségi meghatározást tesznek lehetővé, csak az analitikum jelenlétéről, illetve hiányáról adnak felvilágosítást, de vannak félmennyiségi és mennyiségi meghatározásra alkalmas gyors tesztek is. E tesztek előnye elsősorban a gyorsaságban, mintaelökészítés egyszerüségében és az alacsony költségekben rejlik. Ugyanakkor vannak hátrányai is. Meg kell említeni a megbízhatóság kérdését, hisz gyakran álpozitív eredményeket kapunk. E teszteknél kívánalom, hogy az álpozitív eredményeket 5\% alatt kell tartani, míg az álnegatív eredményeket ki kell küszöbölni. A gyorsmódszerek közül használatukat tekintve a legegyszerübb technikák a tesztcsíkok (lateral flow device (LFD)). Alkalmazásuk nem igényel képzett személyzetet, rendkívül gyors, a termékek minőségének ellenőrzésére az átvétel helyén is alkalmazható. Yang és mtsai (2010) búza illetve kukorica DON tartalmának kimutatására alkalmas kolloid arannyal jelzett DON specifikus monoklonális antitestet tartalmazó immunkromatográfiás tesztcsíkot alakítottak ki. A teszt kimutatási határa 50 ng/ml volt, míg az analízisidő 10 perc. Zhi-Bing és mtsai (2012) hasonló kompetitív rendszerü kolloid arannyal konjugált antitestet tartalmazó immunkromatográfiás tesztcsíkot fejlesztettek ki DON és zearalenon együttes kimutatására búza és kukoricamintákból. A teszt kimutatási határa DON esetén $1000 \mu \mathrm{g} / \mathrm{kg}$, míg ZON esetén $60 \mu \mathrm{g} / \mathrm{kg}$ volt. Egy mérés kb. 5 percet vett igénybe. Kolosova és mtsai (2008) publikációjukban olyan LFD tesztet mutattak be, amely két méréstartományban müködött $250-500 \mu \mathrm{g} / \mathrm{kg}$ és $1000-2000 \mu \mathrm{g} / \mathrm{kg}$ tartományban. A mintánál metanol-víz (80/20\% v/v) eleggyel történő extrakciót végeztek. Számos kereskedelmi forgalomban is kapható tesztcsík létezik, mint a Reveal for DON SQ (Neogen Corp. USA), amely árpa, zab, búza, búzakorpa, liszt DON tartalmának félmennyiségi meghatározására alkalmas az AccuScan leolvasó alkalmazásával. A müszer a tételeket négy osztályba sorolja: negatív a minta, 
ha a minta DON tartalma $\leq 0,5 \mathrm{mg} / \mathrm{kg}$, pozitív, ha $0,5 \mathrm{mg} / \mathrm{kg} \leq \mathrm{DON} \leq 1 \mathrm{mg} / \mathrm{kg}$, valamint $1 \mathrm{mg} / \mathrm{kg}$ $\leq \mathrm{DON} \leq 2 \mathrm{mg} / \mathrm{kg}$, valamint DON $\geq 2 \mathrm{mg} / \mathrm{kg}$. Hasonlóan alkalmazható a RIDAQUICK DON (RBiopharm Ag. Germany) nevü gyorsteszt, ami gabonák DON tartalmának meghatározására alkalmas. A teszt kimutatási határa $0,5 \mathrm{mg} / \mathrm{kg}$ DON. A DON-V teszt (Vicam) durumbúza, liszt, tészta DON tartalmának mennyiségi meghatározására alkalmas $0-5 \mathrm{mg} / \mathrm{kg}$ tartományban. A teszt kimutatási határa 0,2 mg/kg (Liu et al., 2012). A QuickTox Kit for Quick Scan DON (EnviroLogix, USA) megkapta az AOAC International Research Institute Performance Tested Method $^{\mathrm{SM}}$ tanusítványát. A teszt 0-5 mg/kg közti tartományban alkalmas DON meghatározására búza, kukorica, búzakorpa, búzaliszt és árpa mintákból (Albert et al., 2013).

Említést kell tenni az elektronikus orr, mint kémiai szenzor alkalmazásáról a gyors vizsgálati módszerek között. Campagnoli és mtsai (2011) bemutattak egy olyan elektronikus orr fémoxid félvezető (EN-MOS) szenzort, ami alkalmas a durum búza minták DON tartalmuk alapján történő megkülönböztetésére. A rendszer három csoportba osztályozta a mintákat aszerint, hogy szennyezett vagy nem szennyezett, illetve, hogy a DON tartalma a határ alatt $(1,75 \mu \mathrm{g} / \mathrm{kg})$ vagy felett van. Egy másik kutatócsoport árpa DON tartalmának meghatározási lehetőségét vizsgálta az illékony komponensek elektronikus orral történő vizsgálatával (Olsson et al., 2002).

\subsubsection{ELISA módszerek}

Ma a mikotoxinok kimutatására legáltalánosabban használt módszer az enzimhez kapcsolt immunoszorbens vizsgálat (ELISA). Az ELISA vizsgálat nem igényel extra tisztítási vagy dúsítási lépést, a minta extrakciót követően azonnal vizsgálható. Maragos és mtsai (2006) DON és NIV szimultán meghatározására alkalmas kompetitív direkt és indirekt ELISA módszert fejlesztettek ki, monoklonális antitestet alkalmazva. Ji és mtsai (2011) búzából történő kimutatásra alkalmas indirekt kompetitív ELISA módszert hoztak létre. Kétféle, BSA-hoz és OVA-hoz kötött 3-Ohemiszukcinil-DON konjugátumot készítettek a vizsgálathoz, illetve a DON specifikus egér antiszérum termeltetéséhez. A lineáris mérési tartomány 10-100000 ng/ml közt volt. Ehhez hasonlóan Dos Santos és mtsai (2011) BSA-hoz kötött DON-hemiglutarát konjugátumot készítettek, amellyel monoklonális antitesteket állítottak elő, a DON vizsgálatára alkalmas indirekt kompetitív ELISA teszt kialakításához. A DON kimutatási határa $177 \mu \mathrm{g} / \mathrm{kg}$ volt. A kereskedelmi forgalomban kapható DON kimutatására alkalmas ELISA teszteket az 1. táblázat mutatja be. 
1. táblázat: Kereskedelmi forgalomban kapható DON kimutatására alkalmas ELISA tesztek

\begin{tabular}{|c|c|c|c|}
\hline Teszt neve & Alkalmazható mátrix & LOD & Gyártó \\
\hline AgraQuant ${ }^{\circledR}$ DON & $\begin{array}{l}\text { árpa, árpamaláta, } \\
\text { kukorica, kukoricakorpa, } \\
\text { cirok, zab, búzaliszt, } \\
\text { szója }\end{array}$ & $0,2 \mathrm{mg} / \mathrm{kg}$ & Romer Labs \\
\hline Green Spring DON & $\begin{array}{l}\text { sör } \\
\text { mogyoró, kukorica, } \\
\text { gabonák, } \\
\text { búza, maláta, takarmány }\end{array}$ & $\begin{array}{c}10 \mu \mathrm{g} / \mathrm{L} \\
200 \mu \mathrm{g} / \mathrm{kg}\end{array}$ & $\begin{array}{c}\text { Shenzhen Lvshiyuan } \\
\text { Biotechnology Co. }\end{array}$ \\
\hline DON EIA & $\begin{array}{l}\text { sör } \\
\text { gabona } \\
\text { takarmány és ételek }\end{array}$ & $\begin{array}{l}10 \mu \mathrm{g} / \mathrm{kg} \\
30 \mu \mathrm{g} / \mathrm{kg} \\
30 \mu \mathrm{g} / \mathrm{kg}\end{array}$ & $\begin{array}{c}\text { ELISA Technologies } \\
\text { Inc. }\end{array}$ \\
\hline Veratox for DON HS & $\begin{array}{l}\text { búza, kukorica, árpa, zab, } \\
\text { árpa maláta, feldolgozott } \\
\text { gabonák }\end{array}$ & $5 \mu \mathrm{g} / \mathrm{kg}$ & Neogen Corp. \\
\hline $\begin{array}{l}\text { MaxSignal }^{\circledR} \\
\text { Deoxynivalenol (DON) } \\
\text { ELISA Test kit }\end{array}$ & $\begin{array}{l}\text { gabona, takarmány, } \\
\text { füszer, } \\
\text { szérum, } \\
\text { vizelet }\end{array}$ & $\begin{array}{c}15-1000 \mu \mathrm{g} / \mathrm{kg} \\
15 \mu \mathrm{g} / \mathrm{kg} \\
12,5 \mu \mathrm{g} / \mathrm{kg} \\
25 \mu \mathrm{g} / \mathrm{kg}\end{array}$ & Bioo Scientific Co. \\
\hline DON ELISA kit & gabona, takarmány & & Frontier-Institute Co. \\
\hline $\begin{array}{l}\text { DEOXYNIVALENOL } \\
\text { ELISA (5121 DON) }\end{array}$ & $\begin{array}{l}\text { gabona, élelmiszer, } \\
\text { takarmány, sör, }\end{array}$ & $30 \mu \mathrm{g} / \mathrm{kg}$ & EuroProxima \\
\hline $\begin{array}{l}\text { RIDSCREEN }{ }^{\circledR} \text { FAST } \\
\text { DON }\end{array}$ & $\begin{array}{l}\text { búza, maláta, árpa, } \\
\text { kukorica }\end{array}$ & $0,2 \mathrm{mg} / \mathrm{kg}$ & r-Biopharm GmbH \\
\hline
\end{tabular}


Az ELISA tesztek egyszerü és olcsó megoldást jelentenek a mikotoxin vizsgálatokban, ugyanakkor a kompetitív rendszernél a kis koncentrációknál gyakran a pontossága nem megfelelö, és csak bizonyos élelmiszer-mátrixokban alkalmazható.

Hasonlóan ígéretes és igen gyorsan fejlődő technika a fluoreszcens polarizációs immunoassay (FP). Maragos és mtsai (2002) búzából és kukoricából történő DON meghatározásra fejlesztett ki fluoreszcens polarizációs immunoassay módszert, azonban az általuk kialakított rendszer kb. 20\%-kal nagyobb DON koncentrációt mért a mátrixhatás miatt. Lippolis és mtsai (2006) a Maragosék által kifejlesztett módszert fejlesztették tovább. Vizsgálataikat durum búza, dara és tészta minták alkalmazásával végezték, és figyelembe vették a minta mátrixhatásából adódó jeleltolódást is. A kimutatási határ mind három mátrix esetén $0,10 \mu \mathrm{g} / \mathrm{g}$ volt. Az eredmények igen jó egyezést mutattak $(r>0,995)$ a HPLC referencia módszerrel mért értékekkel.

\subsubsection{Immunszenzorok}

Az eddig bemutatott technikák ugyan gyors és olcsó megoldást nyújtanak a mikotoxin meghatározásban, de a mérések reprodukálhatósága, a mérések megbízhatósága a különböző mátrixokban és a kimutatási határ számos problémát vet fel. E problémákra nyújthat megoldást a különböző bioszenzorok alkalmazása a mikotoxin vizsgálatokban. A bioszenzorok, azon belül is az immunszenzorok alkalmazásával lehetőség nyílik a gyors, olcsó, megfelelően szelektív és szenzitív toxin mérésekre. A szenzor nagyérzékenységű, sorozatmérésekre is alkalmas módszerek kifejlesztését teszi lehetővé.

Napjainkban a jelölésmentes immunszenzorok fejlesztése került előtérbe. Számos kutatócsoport végez jelölésmentes mikotoxin szenzor fejlesztéseket, elsősorban aflatoxin és ochratoxin meghatározására, de csak igen keveset alkalmaznak DON kimutatásra. Kadota és mtsai (2010) búza DON és NIV tartalmának meghatározására kifejlesztett SPR alapú immunszenzort mutattak be, ahol a kompetitív vizsgálati módszerhez monoklonális ellenanyagot alkalmaztak, és a mintát előzetesen egy DON specifikus immunaffinitás oszlopon tisztították. A kimutatási határ 0,2 és $0,1 \mathrm{mg} / \mathrm{kg}$ volt NIV és DON esetében. Egy másik kutatócsoport olyan SPR alapú DON szenzort alakított ki, ahol felismerő elemként az arany chip felületre molekuláris lenyomatú polipirrol (MIPPy) filmet hozott létre. A MIPPy-SPR szenzor lineáris méréstartománya 0,1-100 ng/ml közt volt (Choi et al., 2011). Meneely és mtsai (2010) búzából, búza alapú reggelizőpehelyből, illetve kukorica alapú bébiételből történő DON meghatározására alkalmas, igen gyors mérésre képes (9 perc/minta) SPR szenzort fejlesztettek. Van der Gaag és mtsai (2003) szimultán DON, aflatoxin $\mathrm{B}_{1}$, fuminosin $\mathrm{B}_{1}$ és zearalenon mikotoxin meghatározásra használható SPR bioszenzort alakítottak ki. A szimultán meghatározást négy sorba kapcsolt áramlási cella tette 
lehetővé. Az SPR-hez hasonló jelölésmentes bioszenzort fejlesztett ki Maragos kutatócsoportja (2011). A biolayer interferometriás immunszenzorral búzaliszt DON tartalmát határozták meg. A mérés igen gyors (7 perc/minta) és a kimutatási határ $100 \mu \mathrm{g} / \mathrm{kg}$ volt. Amennyiben a vizsgálathoz kolloid arannyal konjugált antitestet alkalmaztak, az analízisidö lecsökkent 6 perc/mintára és a kimutatási határ is $90 \mu \mathrm{g} / \mathrm{kg}$-ra (Maragos et al., 2012).

\subsection{Vitellogenin mint biomarker a környezetanalitikában}

Az utóbbi évtizedekben bebizonyosodott, hogy az ipari, iparszerü mezőgazdasági és egyéb társadalmi tevékenység nyomán a környezetbe kerülő szennyező anyagok különféle humán- és ökotoxikológiai hatásokat váltanak ki. A társadalom manapság egyre több gyógyszert és háztartási vegyszert használ fel. Az iparszerü mezőgazdaságban a termelékenység és a minőség fenntartásában elengedhetetlen a növényvédőszerek alkalmazása. Az intenzív állattartásban gyógyszerek nélkül nem lehet tartani a termelési szintet. Ezek az anyagok közvetlen a környezetbe kerülve, illetve ezek metabolitjai a vizelettel, széklettel ürülve bekerülnek a szennyvízbe és szennyvíziszapba. A szennyvíztisztító telepek tisztítási folyamatai során ezek a vegyületek csak részlegesen bomlanak le, és az ipar növekvő termelése által túlterhelt szennyvíztisztító telepek nem képesek teljesen szennyeződésmentessé tenni a folyókba engedett szennyvizet (Boros, 2004). Mivel ezek a vegyületek jól adszorbeálhatóak, ezért a folyók, patakok medrében az iszapra kötődve ún. biofilmen feldúsulhatnak és onnan a vízi élővilág szervezetébe juthatnak, ahol a zsírraktárakban feldúsulnak, így a szermaradványok az egész táplálékláncban kimutathatók.

Az utóbbi évtizedben egyre nagyobb figyelmet kaptak azok a környezetbe kerülö antropogén kémiai szennyező anyagok, melyekről bebizonyosodott, hogy képesek megváltoztatni, illetve megzavarni mind az állatok, mind az emberek hormonrendszerének müködését. Az Európai Unió 1999 óta jogi keretek közt szabályozza az endokrin zavaró anyagok alkalmazását és meghatározta ezek tiltó listáját, amely azóta folyamatosan bővül (Commission of the European Communtities, 1999). Az endokrin zavaró hatású anyagok analitikájában, az ún. hatás alapú biomonitorozásban lehet nagy segítségünkre az endokrin zavaró hatás felléptét jelző biomarker jelenlétének detektálása. Ilyen specifikus biomarker a vitellogenin (Vtg) fehérjecsalád (ArcandHoy et al., (1998), Hutchinson et al., (2006).

\subsubsection{Hormonális müködésre ható vegyületek}

A hormonális müködésre ható vegyületeket (EDCs) az irodalomban nagyon sokféleképpen definiálták, de a leggyakrabban használt és elfogadott meghatározás a következő: A hormonháztartást megváltoztató anyagoknak azokat az exogén vegyületeket nevezzük, amelyek a 
szabályozásban és a növekedésben szerepet játszó természetes hormonok termelését, kibocsátását, transzportját, kötődését, reakcióját, vagy kiürülését zavarják (United States Environmental Protection Agency (USEPA), 1997). Ezek az anyagok a hormonrendszer müködését számos módon módosítják (Mendes, 2002):

> Ösztrogénreceptorokhoz kötődnek és aktiválják azokat, így az endogén hormonok hatását utánozzák.

> Ösztrogénreceptorokhoz kötődnek, de nem aktiválják azokat, így akadályozzák a természetes endogén hormonok hatásának megjelenését.

> Megváltoztatják a természetes hormonok szintézisének és metabolizmusának módját

Módosítják a természetes hormonok metabolizációjának útját.

Az endokrin zavaró hatású anyagok csoportjába számos különböző típusú vegyület tartozik, mint a természetes hormonok (fitoösztrogének), gyógyszerek (pl. hormonális fogamzásgátlók), peszticidek (DDT, lindán), fenolok (BPA, APE), ftalátok, poliklórozottbifenilek (PCB), lángfogók, fémek, halogénezett többgyürűs égési melléktermékek (dioxinok). Az EDCs-re jellemző, hogy stabilak, nehezen bomlanak le, évekig intakt formában megmaradnak az élő szervezetekben és a természetben, az állati és emberi szervezet zsírraktáraiban felhalmozódnak. E kémiai anyagokra legérzékenyebbek a vizes környezetben élő állatok, hisz egész testfelületükkel érintkeznek a vízzel, innen szerzik táplálékukat és szaporodásuk is vízhez kötött. Számos kutatócsoport vizsgálta a vízi élővilágra gyakorolt hatásukat, ahol első sorban a nemi funkciók megváltozását, megszünését (hermafroditizmus, szupernő szindróma, hímeknél vitellogenin termelés), eltolódott nőstény-hím születési arányt, rákos megbetegedéseket, immunrendszer károsodást, viselkedési zavarokat, tojáshéj elvékonyodást írtak le.

\subsubsection{Vitellogenin}

Halakban, kétéltủekben a máj által előállított vitellogenin a legfontosabb alkotóeleme a szikfehérjéknek (Tyler et al., 1991). A vitellogenin normál esetben csak az ivarérett nőstények vérében mutatható ki. A vérplazma vitellogenin koncentrációja a nőstény egyedekben vitellogenezis kezdetén hirtelen megnő, és a növekedési fázis végéig azonos szinten marad. A vér magas vitellogenin koncentrációja a vitellogenezis alatt az oocyta növekedését eredményezi. Hím, illetve ivaréretlen egyedek vérében nem mutatható ki vitellogenin, azonban a hím egyedek is rendelkeznek Vtg-t kódoló génekkel és ösztrogén receptorokkal, így az EDCs-k hatására, a hímek vérszérumában is abnormális szintre emelkedhet mennyiségük (Sumpter and Jobling, 1995; 
Wheeler et al., 2005). Ezért a vízi és kétéltü hím állatok vérében található Vtg alkalmas biomarkernek bizonyult a környezetben lévő endokrin zavaró anyagok jelenlétnek felismeréséhez.

EDCs-k monitorozására leggyakrabban használt teszt hal a közönséges ponyt (Cyprinus carpio), hisz világszerte igen elterjedt halról van szó, és igen jól tolerálja a szennyezett környezetet is. Japánban egy nagyváros folyóhálózatán a Tama folyón végeztek vizsgálatokat a lehetséges környezeti szennyezők kimutatására. A vizsgálatban hím ponytok vitellogenin szintjét vizsgálták, amelyeket a szennyvíztisztító telepről kifolyó élővízből fogtak ki. A kifogott halaknál igen magas Vtg szinteket mértek és szövettani eltéréseket mutattak ki a herékben (Nakamura et al., 1998). Purdom és mtsai (1994) Angliában hím szivárványos pisztrángokat telepítettek a szennyvíztisztító telepek kilépő ágához. Vizsgálatukban bebizonyították, hogy a hím halakban a szennyvíz által kiváltott Vtg szintézis indult meg.

\subsubsection{Vitellogenin meghatározásra alkalmazott technikák}

Számos analitikai és bioanalitikai módszert alkalmaznak biológiai minták vitellogenin szintjének kimutatására. A leggyakrabban alkalmazott nagymüszeres analitikai eljárás vitellogenin meghatározására a tömegspektrométerrel kapcsolt folyadék kromatográfia (LC-MS). Cohen és mtsai (2006) egy igen egyszerü módszert mutattak be szivárványos pisztráng és lazac vérszérumának vitellogenin meghatározására. A vizsgálatban a kontroll vérmintákat és a $\beta$ ösztradiollal kezelt halak vérmintáit tripszinnel kezelték, majd a jellemző ún. „,signature peptide”et elválasztották és kvadrupól-repülési idő hibrid tömegspektrométerrel kapcsolt nagyhatékonyságú folyadékkromatográfiás (HPLC-QTOF-MS) módszerrel vizsgálták.

Van Veld és mtsai (2005) egy univerzális elektroforetikus fehérje meghatározási módszert ismertettek, ami a vitellogeninek nagy molekula tömegén és kimagasló foszfoszerin tartalmán alapult. A kísérletben tüzcselle (Pimephales promelas), fogasponty (Fundulus heteroclitus), szúnyogírtó fogasponty (Gambusia holbrooki) eredetű vér és mukozális fehérje mintákat választottak el poliakrilamid gélelektroforézissel (SDS-PAGE). A vizsgálat lehetővé tette különböző fajok nőstény, illetve ösztradiollal kezelt hím egyedek vitellogenin koncentrációjának meghatározását.

Vitellogenin meghatározásához gyakran alkalmaznak molekuláris biológiai módszereket is. An és mtsai (2006) kvantitatív reverz transzkripciós polimeráz láncreakciós (Q-RT-PCR) eljárást dolgoztak ki Vtg mRNS mennyiségi meghatározására tengeripérhalból (Mugil soiuy). Barucca és kutatócsoportja (2006) különböző specifikus primert terveztek számos mediterrán halfaj Vtg mRNS koncentrációjának RT-PCR eljárással történő meghatározásához. Vizsgálatukban ivaréretlen európai angolna (Anguilla anguilla) egyedeket vizsgáltak, amelyeket 
17- $\beta$-ösztradiollal kezeltek, melynek következtében az egyedekben beindult a Vtg mRNS szintézis, bizonyítva az ösztrogénhatás iránti érzékenységüket, illetve a kialakított primerek specifikusságát.

A leggyakrabban használt Vtg meghatározási eljárás az ELISA módszer. Számos különböző halfajból történő Vtg kimutására alkalmas Vtg specifikus sandwich ELISA (sELISA) módszert fejlesztettek már ki, mint pl.: ponty (Cyprinus carpio) (Kera et al., 2000), tüzcselle (Pimephales promelas) (Parks et al., 1999), zebrahal (Brachydanio rerio) (Brion et al., 2002) esetén. Liao és mtsai (2006) kínai fürge cselle (Gobiocypris rarus) Vtg szintjének meghatározására alkalmas kompetitív ELISA módszert fejlesztettek ki. A meghatározáshoz a halból tisztított Vtg-t és az ellene nyulakban termeltetett poliklonális antitestet alkalmazták. A kialakított ELISA rendszerrel olyan fiatal kínai fürgecselle egyedek Vtg koncentrációját határozták meg, melyeket etetési kísérletben három különféle eredetű táppal etettek: szennyvízből fogott csővájó féreggel, sórák lárvával (Aretmia nauplii) és kereskedelmi haltáppal. A kísérlet célja az volt, hogy megvizsgálják, hogy a táplálékokban jelen levő ösztrogén hatású összetevők az egyedekben beindítják-e a vitellogenezist. A táplálék ösztrogénhatású összetevőinek mennyiségét GC-MS módszerrel határozták meg. Eredményeik szerint az ELISA rendszerrel mért vitellogenin válaszok igen jó egyezést mutatott a táplálékból GC-MS analízissel meghatározott ösztrogénhatású anyagok mennyiségével, továbbá így bebizonyosodott, hogy a kínai fürgecselle igen érzékeny modell hal a vizi környezet ösztrogén hatású EDCs-kel történő szennyezettségének monitorozására.

A környezetszennyezés hatásának kimutatására a békák gyakran jobb bioindikátorok mint a halak, ezért Vtg kimutatásra alkalmas ELISA módszerek nem csak halak, de kétéltüek és hüllők esetében is kidolgozásra kerültek. Egy igen érzékeny sELISA módszer került kialakításra ökörbéka (Rana catesbeiana) Vtg szintjének mennyiségi meghatározására. A módszer mérési tartománya 9,4 ng/ml-1200 ng/ml közt volt, míg a kontroll hím ökörbéka vérszérumhoz adott Vtg visszanyerése 92,0-108,8\% (Li et al., 2006). Sifuentes-Romero és mtsai (2006) 17- $\beta$-ösztradiollal kezelt hím fekete teknősök (Chelonia mydas agassizii) véréből ioncserés kromatográfiával tisztítottak Vtg-t. A tisztított Vtg egy 500000 Da dimer volt, ami két azonos monomerből állt. A fekete teknős Vtg ellen termelt poliklonális antitest igen magas aktivitást és specificitást mutatott mind az ELISA, mind a Western blot analízis alapján. A rendszer mérési tartománya $15 \mathrm{ng} / \mathrm{ml}$ és $2 \mu \mathrm{g} / \mathrm{ml}$ közt volt.

Az utóbbi évtizedben a gyorskimutatási technikák fejlesztése egyre inkább a gyors, olcsó egyszerü, sorozatmérésekre alkalmas technikák felé irányult, amiben a bioszenzorok igen ígéretes és érdekes alternatívát jelentenek. Darain és mtsai (2005) amperometriás immunszenzort hoztak létre ponty Vtg gyors meghatározására. A szenzor munkaelektródjaként vezető polimerrel borított szitanyomott szén elektródot alkalmaztak, aminek a felületére rögzítették a tormaperoxidáz 
enzimet és a ponty Vtg elleni specifikus monoklonális antitestet. A minta Vtg tartalma és a glükózoxidázzal kapcsolt Vtg (GOX-Vtg) glükóz mint szubsztrát jelenlétében versengnek a szabad antitest kötőhelyekért. A minta Vtg tartalma fordítottan arányos a szenzor felületére kötődött GOX-Vtg mennyiségével. Az enzim által indukált jelet amperometriásan detektálták. A szenzor lineáris mérési tartománya 0,25 és $7,8 \mathrm{ng} / \mathrm{ml}$ közt volt, míg a kimutatási határ $0,09 \mathrm{ng} / \mathrm{ml}$. Ugyanez a kutatócsoport vizsgálta Vtg kimutatásának lehetőségét elektrokémiai impedancia spektroszkópia technikával (Darain et al., 2004). Fukada és mtsai (2003) kemilumineszcens immunassay alapú kimutatási módszert fejlesztett ki ponyt Vtg meghatározására. A módszer lineáris mérési tartománya 1,95 és $1000 \mathrm{ng} / \mathrm{ml}$ közt volt. Soh és mtsai (2002) tanulmányukban egy szekvenciális injektálásos analízis technikát mutattak be ponyt vitellogenin meghatározására. A módszer kimutatási határa $5 \mathrm{ng} / \mathrm{ml}$ volt. Bulukin és mtsai (2007) egy jelölésmentes felületi plazmon rezonancia (SPR) alapú optikai immunszenzort fejlesztettek ki ponty Vtg szintjének meghatározására. A szenzor alkalmas volt a Vtg ppm tartományban történő kimutatására mind vérszérumból, mind mukózus mintákból. A mérés viszonylag gyors, 20 perc/minta volt. 


\section{CÉLKITŰZÉSEK}

Doktori munkám célja OWLS alapú immunszenzorok fejlesztése volt élelmiszer- és környezetanalitikai alkalmazásra. Kísérleteimben búza deoxynivalenol-tartalmának vizsgálatára alkalmas immunszenzor, illetve EDCs szennyezőanyagok jelenlétének kimutatására biomarkernek tekinthető vitellogenin fehérje meghatározására alkalmas szenzor kialakítását tüztem ki célul, béka (vöröshasú unka, Bombina bombina) és hal (ponty, Cyprinus carpio) egyedekböl. A megvalósítás során a legfontosabb feladat a szenzor kialakításához szükséges immunanyagok előállítása, a direkt és indirekt mérési módszer alkalmazási lehetőségének vizsgálata, a mérési rendszer optimalizálása, valamint az új mérési módszerek felhasználhatóságának igazolása volt. A kifejlesztett technika megbízhatóságának ellenőrzéseként az OWLS immunszenzor eredményeit az élelmiszer- és környezetanalitikában alkalmazott ELISA referencia meghatározási módszerrel hasonlítottam össze. A kialakítandó mérési eljárásokkal célom olyan technika kifejlesztése volt, ami gyors, egyszerü, sorozatmérésekre alkalmas és lehetővé teszi az analitikum nagy érzékenységgel és szelektivitással történő meghatározását. 


\section{ANYAGOK ÉS MÓDSZEREK}

\subsection{Anyagok}

A szenzor felület szilanizálásához az $\gamma$-amino-propil-trietoxi-szilánt (APTS), valamint az aktiválásához a glutáraldehidet, a borostyánkősavanhidridet, az 1-etil-3-(3-dimetil-amino-propil)karbodiimid (EDC), valamint az N-hidroxi-szukcinimidet (NHS) a Sigma-Aldrich Co. Ltd.-től (St. Louis, MO, USA) szereztem be.

Az immunizáláshoz használt komplett és inkomplett Freund adjuváns a Sigma-Aldrich Co. Ltd-től (St. Louis, MO, USA) származott. A tormaperoxidázzal jelölt anti-nyúl kecske IgG konjugátum a Jackson ImmunoResearch Inc. (USA) terméke volt. A kromogén orto-fenildiamin (OPD) és $\mathrm{H}_{2} \mathrm{O}_{2}$ szubsztrát szintén a Sigma-Aldrich Co. Ltd. (St. Louis, MO, USA) terméke volt. Az immunglobulinok tisztításához használt dializáló zsák a SERVA Electrophoresis GmbH terméke. A konjugátumok készítéséhez szükséges marhaszérum-albumin (BSA), ovalbumin (OVA), anti-BSA IgG (2,6 mg/ml) és a 2-amino-2-hidroxi-metil-propán-1,3-diol (TRIS) szintén a Sigma-Aldrich Co. Ltd. (St. Louis, MO, USA) termékei voltak.

A modellkísérleteknél alkalmazott hirudin, tripszin inhibítor, ovalbumin, marha szérum albumin, glükózoxidáz, $\gamma$-globulin és hemocianin a Sigma-Aldrich Co. Ltd.-től (St. Louis, MO, USA) származott.

A deoxynivalenol mikotoxin a Sigma-Aldrich Co. Ltd. (St. Louis, MO, USA) terméke volt.

A vitellogenin méréshez szükséges fehérjék és antitestek a munka során készültek.

A Bradford-féle fehérjemeghatározáshoz BIO-RAD (Cat.\#500-0006) festéket alkalmaztam.

A poliakrilamid-gélelektroforézishez (SDS-PAGE) alkalmazott SDS, valamint az akrilamid (oldott állapotú) a BIO-RAD Laboratories Inc. terméke volt. A $\beta$-merkaptoetanol a MERCK KGaA terméke volt. A karbamid, TRIS, Coomassie Brilliant Blue G-250 és R-250 festékek a Reanal Finomvegyszergyár Zrt-től származtak. A fixáláshoz használt triklórecetsav a CARLO ERBA Reagents S.A.S terméke volt.

Az ELISA vizsgálatokhoz alkalmazott mikrotiterlemez az Analyzer Kft. terméke volt. A kecskéből nyert anti-nyúl IgG-HRP konjugátum a BIO-RAD Laboratories Inc.-től származott. A szubsztrát-oldat $\left(\mathrm{H}_{2} \mathrm{O}_{2} / \mathrm{OPD}\right)$, valamint az inhibítor oldat a Sigma-Aldrich Co. Ltd. (St. Louis, MO, USA) termékei voltak.

Minden további vegyszer analitikai minőségü kereskedelmi termék volt. 


\subsection{Módszerek}

\subsubsection{OWLS mérőrendszer felépítése}

A mérésekhez OW 2400 típusú amino funkcionalizált integrált optikai hullámvezető szenzort (chip) (MikroVakuum Kft, Budapest) használtam. A vizsgálatokat a MikroVakuum Kft. által gyártott OWLS 120-as típusú berendezéssel végeztem. A műszert a BioSense 2.2 szoftver vezérelte. A berendezés fényforrása lineárisan polarizált He-Ne lézer $(632,8 \mathrm{~nm})$. A szenzor időben állandó, stabil működésének érdekében az OWLS szenzort folyamatosan áramló injektálásos rendszerben (FIA) müködtettem. A szenzort a mérőberendezés mintatartó átfolyó cellájába (küvetta) helyezve használtam. Az állandó áramlási sebességet Gilson Minipulse 3 típusú perisztaltikus pumpa biztosította. A mintatartó átfolyó cella hőmérsékletét az OWLS TC hütő/fütő egység szabályozta. A minta injektálását egy Rheodyne típusú injektorral végeztem, mely $200 \mu 1-$ es mintavevő hurkot tartalmazott. Az eredmények kiértékelését a MikroVakuum Kft. BioSense 2.6 szoftverrel végeztem. A 7. ábra a FIA rendszerrel ellátott OWLS 120 mérőmüszert mutatja be.

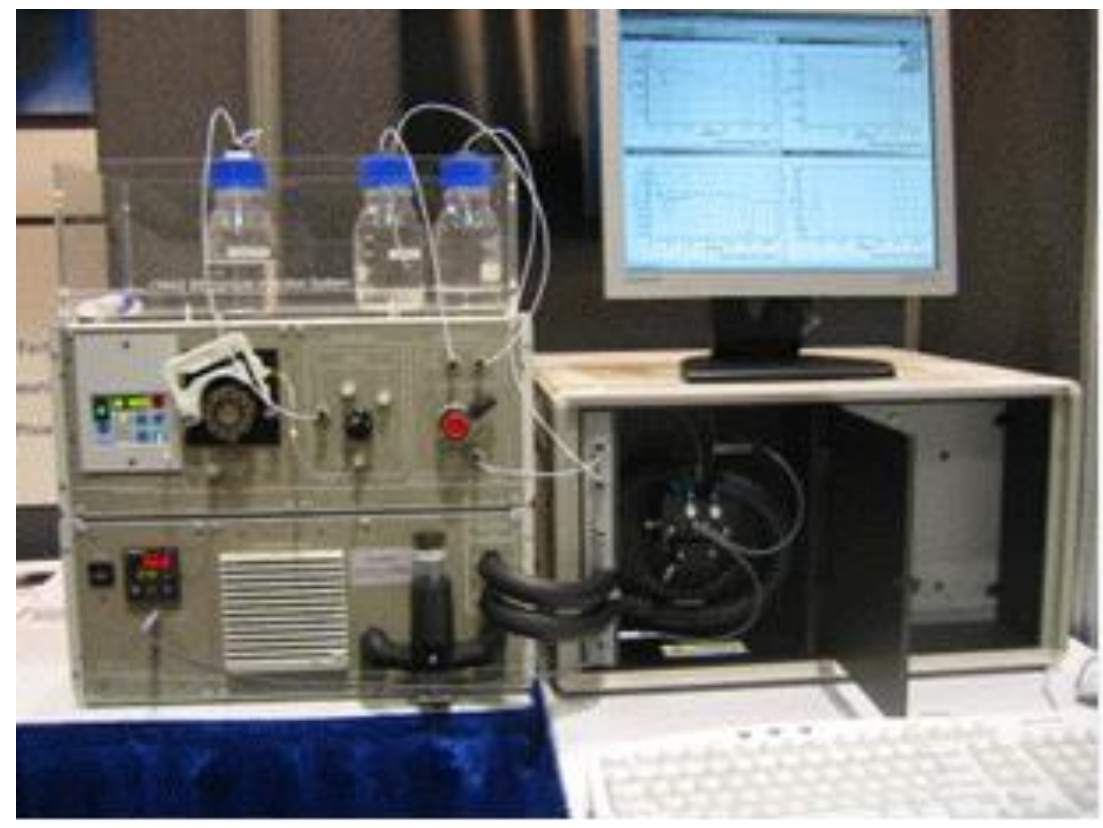

7. ábra: FIA rendszerrel ellátott OWLS mérőmüszer 


\subsubsection{Szenzor felületének módosítása szilanizálással}

A hullámvezető szenzor felülete igen hidrofób, csak kevés hidroxilcsoport található rajta, ami nem alkalmas a biomolekulák közvetlen rögzítésére, a felületet kémiailag módosítani kell. Az egyik leggyakrabban alkalmazott felületmódosítási eljárás a szilanizálás. A szilanizálással különböző funkciós csoportokat lehet biztosítani az alkalmazott szilán molekulának megfelelöen, amihez már a megfelelő kémiai lépésekkel rögzíthetőek a biomolekulák.

Kísérleteimhez a szenzor felületén aminocsoportokat alakítottam ki $\gamma$-amino-propiltrietoxi-szilánt (APTS) alkalmazva (Trummer et al. 2001). A felületmódosításhoz a szenzort előzőleg tisztítani és hidratálni kell. A tisztítást krómkénsavban történő áztatással (1 óra) végeztem, majd a szükséges hidroxilcsoportok kialakításához a tisztított szenzorokat forró vízzel hidratáltam ( $90^{\circ} \mathrm{C}, 1$ óra). A szilanizálás vizes fázisban, bemerítéses technikával történt. A megtisztított és forró vízben hidratált szenzorok felületét az APTS (pH 3) 10\%-os oldatával $75^{\circ} \mathrm{C}$ on, 3 órát kezeltem. Desztillált vízzel való mosás után a képződött szilánréteg stabilizálódása érdekében a szenzorokat hőkezeltem $\left(95^{\circ} \mathrm{C}, 16\right.$ óra), és Eppendorf-csőben tároltam a további felhasználásig.

\subsubsection{Biomolekulák rögzítése EDC/NHS eljárással}

A szenzor felületének módosítása, majd az ezt követő immobilizáció az úgynevezett inkubációs küvettában (MikroVakuum Kft.) történt, ahol az APTS reagenssel kezelt szenzorfelület aminocsoportjait borostyánkősavanhidrides kezeléssel karboxilcsoportokká alakítottam. A karboxilcsoportokat az aminocsoportok származékképzésével hoztam létre, melyhez a chipet 100 $\mu \mathrm{l} \quad 0,2 \%$-os borostyánkősavanhidriddel (dimetil-formamidban oldva) kezeltem szobahőmérsékleten 1 óráig. Ezt követően a szenzort desztillált vízzel mostam, majd $90{ }^{\circ} \mathrm{C}$-on 15 percig szárítottam. Hogy reaktív szukcinimid észtert hozzak létre a felületet 1-etil-3-(3-dimetilamino-propil)-karbidiimiddel (EDC) és N-hidroxi-szukcinimiddel (NHS) kezeltem, ahol 0,4 mol/1 EDC / 0,1 mol/l NHS (1:1) arányú keverékét alkalmaztam. A szenzort ezt követően desztillált vízzel mostam, majd $13 \mathrm{mM-os} \mathrm{pH} \mathrm{5-ös} \mathrm{acetát} \mathrm{pufferrel} \mathrm{mostam} \mathrm{a} \mathrm{felületet,} \mathrm{hogy} \mathrm{biztosítsam} \mathrm{az}$ optimális feltételeket a fehérjék immobilizációjához. A rögzítendő biomolekulákat ugyanebben az acetát pufferben hígítottam és immobilizáltam a felületen. A rögzített biomolekulát tartalmazó szenzort Eppendorf csőben $4{ }^{\circ} \mathrm{C}$-on tároltam a felhasználásig. A mérés indításakor a szabadon maradt reaktív észterkötőhelyeket $1 \mathrm{~mol} / \mathrm{l}$ etanolamin injektálásával blokkoltam. 


\subsubsection{Biomolekulák rögzítése glutáraldehiddel}

Az aminoszilanizált szenzorfelülethez a biomolekulák közvetlen köthetők glutáraldehid segítségével. A rögzítés során a chipet az OWLS mérőmőszer szenzortartójába helyeztem, és a rögzítést FIA rendszerben végeztem. Az alkalmazott áramlási sebesség $0,16 \mathrm{ml} /$ perc volt. A mérőcellán először desztillált vizet áramoltattam, majd a rendszerbe $200 \mu 1$ glutáraldehid oldatot (2,5\% desztillált vizes) injektáltam. A glutáraldehid által okozott effektív törésmutató változást folyamatosan figyelve, amikor a törésmutató változást leíró görbe eléri a maximumot (a szenzor felületén ekkor csak glutáraldehid található), az áramlást 3 percre leállítottam. Ez alatt az idő alatt a glutáraldehid hozzá kapcsolódik a szenzorfelület aminocsoportjaihoz, polimerizálódik, és térhálós szerkezetet alakít ki. Három perc elteltével újra elindítottam az áramlást. Az oldat kimosódását követően a desztillált vizet TRIS pufferre $(42 \mathrm{mmol} / \mathrm{l}, \mathrm{pH} 7,4)$ cseréltem. A biomolekula rögzítése a molekula megfelelő koncentrációjú oldatának injektálásával történt. Az injektálást követően az áramlást hasonlóan a glutáraldehidnél leírtak alapján 3 percre leállítottam. Az áramlás újbóli elindítása után a szenzort rövid ideig pufferrel mostam, majd a meg nem kötődött molekulák eltávolítására $50 \mathrm{mM} \mathrm{HCl-at} \mathrm{injektáltam.} \mathrm{Az} \mathrm{érzékenyített} \mathrm{szenzorfelület} \mathrm{ezt}$ követően alkalmas a minták mérésére.

\subsubsection{Fehérje koncentráció meghatározása Bradford-módszerrel}

A meghatározáshoz $20 \mu 1$ vizsgálandó anyaghoz $1000 \mu \mathrm{l}$ BIO-RAD (Cat.\#500-0006) festék / desztillált víz 1:5 arányú keverékét adagoltam, alaposan összekevertem és 5 perc elteltével a festék fényelnyelési maximumánál $595 \mathrm{~nm}$-en spektrofotométerrel vizsgáltam a fényelenyelés mértékét. A meghatározáshoz a kalibrációt BSA standard oldatok felhasználásával készítettem.

\subsubsection{Tisztított lipovitellin fehérjék előállítása}

A lipovitellin fehérjék tisztítása nőstény ponty és Keleti vöröshasú unka petefészkéből történt az alábbiak szerint.

\subsubsection{Ponty lipovitellin elöállítása}

A Lpv tisztításához a nőstény ponty (Cyprinus carpio) petefészkét izotóniás foszfátpufferben ( $\mathrm{pH} 7,4)$ mostuk, $0,5 \mathrm{~mol} / 1 \mathrm{NaCl}$-oldatban homogenizáltuk $(0,5 \mathrm{~g} / \mathrm{ml}, 12$ óra, 4 ${ }^{\circ} \mathrm{C}$ ). A homogenizátumot 3000 g-n centrifugáltuk, majd a fehérjefrakciót izotóniás foszfátpufferrel (pH 7,4) szemben dializáltuk. A dializátumból a Lpv fehérjét telített ammónium-szulfát (1:1 v/v) adagolásával kicsaptuk, a csapadékot ismét centrifugáltuk 3000 g-n és ammónium-szulfát oldattal mostuk, hogy a színanyagokat eltávolítsuk. A fehérjéket $0,2 \mathrm{~mol} / 1 \mathrm{NaCl}$-oldatban visszaoldottuk, DEAE-cellulóz-oszlopon gélszüréssel tovább tisztítottuk (0,1 mol/1 TRIS puffer, pH 7,8, 0-300 $\mathrm{mmol} / \mathrm{l} \mathrm{NaCl}$ gradiens). A tisztított Lpv-készítményt 37\%-os ammónium-szulfát oldatban $4{ }^{\circ} \mathrm{C}$-on 
csapadékként tároltuk. A tisztított ponty Lpv preparátum koncentrációja $3 \mathrm{mg} / \mathrm{ml}$ volt a Bradfordféle (1986) fehérje meghatározási módszer alapján (1sd. 4.2.5. fejezet).

\subsubsection{Béka lipovitellin elóállítása}

Lipovitellin tisztításához a nőstény Keleti vöröshasú unka (Bombina orientalis) homogenizált petefészkét használtuk. A béka Lpv előállítás lépései megegyeztek az 4.2.6.1. fejezetben ismertetett ponyt Lpv előállítással. A béka Lpv preparátum koncentrációja $3 \mathrm{mg} / \mathrm{ml}$ volt a Bradford-féle módszer szerint.

\subsubsection{DON-fehérje konjugátum ellenőrzése izoelektromos fókuszálással}

A DON-fehérje konjugátumot tartalmazó mintákat fehérjeoldó pufferben ( $8 \mathrm{M}$ karbamid, $32 \mathrm{mM}$ ditio-treitol és $11,5 \%(\mathrm{w} / \mathrm{v})$ glicerin) oldottam és $15-15 \mu$ l-t vittem fel a gélre. A fehérjék izoelektromos fókuszálását 7,2 M karbamidot tartalmazó 4,35\%-os poliakrilamid gélben végeztem pH:3-10 tartományban Multiphor II készüléken (Pharmacia LKB Biotechnology). Anód oldatként $5 \%(\mathrm{w} / \mathrm{v})$-os foszforsav oldatot, katódként pedig 2\%(w/v)-os $\mathrm{NaOH}$-ot használtam. Az izoelektromos fókuszálás paraméterei a következők voltak (2. táblázat):

2. táblázat: Izoelektromos fókuszálás során alkalmazott paraméterek

\begin{tabular}{|l|l|l|l|l|}
\hline \multicolumn{1}{|c|}{ Lépés } & \multicolumn{1}{|c|}{ Idő (perc) } & Feszültség (V) & Áramerősség (mA) & Teljesítmény (W) \\
\hline 1. & 60 & $\operatorname{max.2500}$ & $\operatorname{max.} 15$ & konst. 4 \\
\hline 2. & 60 & $\max .2500$ & $\max .5$ & max. 20 \\
\hline 3. & 40 & $\max .2500$ & $\max .6$ & max. 20 \\
\hline
\end{tabular}

A fókuszálás befejezése után a fehérjéket fixáltam, 15 percig $15 \%(\mathrm{w} / \mathrm{v})$-os triklór-ecetsavban rázatva, majd Coomassie Brilliant Blue G-250 festékkel detektáltam.

\subsubsection{Lipovitellin preparátumok ellenőrzése SDS-PAGE módszerrel}

A Lpv-preparátumok tisztaságát nátrium-dodecil-szulfát poliakrilamid-gélelektroforézissel (SDSPAGE) vizsgáltam (Hajós és Idei, 2001). Ehhez a tisztított ponty Lpv fehérjét feloldottam 12,5 ml fehérjeoldó pufferben (0,75 g SDS, 0,189 g TRIS, 2,5 ml glicerin, 2,5 $\mathrm{ml} \beta$-merkapto-etanol, desztillált víz, pH 6,8). A mintákból 2,5; 5,0; 8,0; 10,0 $\mu$ l-t vittem fel a gélre. Béka eredetű Lpv esetén 8-12 $\mu$ l tisztított Lpv mintát oldottam fehérjeoldó pufferben és vittem fel a gélre. Molekulatömeg markerként 29000, 37000, 51000, 96000, 115000, 200000 Da fehérjét tartalmazó standardot alkalmaztam. A fö gél 12\%-os (akrilamidra nézve) volt, ami 3,2 $\mathrm{ml} 30 \%$-os akrilamid/bis-akrilamid 29:1 arányú keverékéböl, 1,8 ml TRIS-ből (2 mol/l, pH 8,8), $50 \mu 1$ SDSböl $(10 \%), 2,85 \mathrm{ml}$ desztillált vízböl, $6 \mu$ l tetrametil-etilén-diamin és $50 \mu \mathrm{l}$ ammónium- 
perszulfátból (10\%(w/v)) állt. A gyüjtő gél 6\%-os volt, ami 0,5 ml 30\%-os akrilamid/bis-akrilamid 29:1 arányú keverékéből, $330 \mu$ l TRIS-böl (0,5 mol/1, pH 6,8), 27,5 $\mu 1$ SDS-ből (10\%), 1,6 ml desztillált vízből, $3 \mu 1$ tetrametil-etilén-diamin és $25 \mu 1$ ammónium-perszulfátból $(10 \%(\mathrm{w} / \mathrm{v}))$ állt. Az alkalmazott távtartó $0,75 \mathrm{~mm}$ volt. A mintafelvitelt követően a gélt elektroforézis cellába helyeztem. Az elektroforézis kamrát futtatási pufferrel (3,03 g TRIS, 1 g SDS, 14,4 g glicin 1000 ml-re desztillált vízzel kiegészítve) töltöttem fel. A vizsgálatokat BIO-RAD Mini Protean 3 Cell készüléken végeztem. A gélt $200 \mathrm{~V}$-on, max. $400 \mathrm{~mA}$-en 55 percig futtattam, majd 20\%-os triklórecetsav oldatban 20 percig fixáltam. Háromszori mosást (100 ml etanol, $50 \mathrm{ml}$ ecetsav, 850 ml desztillált víz) követően Coomassie Brilliant Blue R-250 festékkel festettem meg a gélt.

\subsubsection{ELISA eljárás referencia vizsgálatokhoz}

Az ELISA vizsgálatokat 96-üreges ELISA mikrotálcán a szilárd fázisú immunassay elve alapján végeztem el (Hegedűs et al. 2000). A mikrotiterlemezeket üregenként $100 \mu$ l antigénnel vagy antigénkonjugátummal $\left(1 \mu \mathrm{g} / \mathrm{ml}, 0,1 \mathrm{~mol} / 1\right.$ karbonátpufferban, $\mathrm{pH} 9,6$; éjszakán át $4{ }^{\circ} \mathrm{C}$-on inkubálva) fedtem. A nem specifikus kötőhelyeket $0,01 \mathrm{~mol} / 1 \mathrm{PBS}$ pufferrel $(0,8 \% \mathrm{NaCl}, \mathrm{pH} 7,4)$ való mosás után blokkoltam üregenként $150 \mu$ blokkoló reagenssel (1\% zselatin PBS pufferben, $\mathrm{pH}=7,4) 38^{\circ} \mathrm{C}$-on 1 óra inkubálással. A mikrotiterlemezt $0,2 \%$ Tween 20 detergenst tartalmazó PBS (PBST 0,2) oldattal mostam, majd minden üregbe $50 \mu 1$ standardot vagy mintát és $50 \mu 1$ PBST 0,2 oldattal hígított antiszérum oldatot adtam, és $38^{\circ} \mathrm{C}$-on 60 percig inkubáltam. Újabb mosás után (PBST 0,2), $100 \mu$ l kecskéből nyert anti-nyúl-IgG-HRP konjugátumot (1:12000 hígításban PBST 0,05) adtam, és ismét 60 percig inkubáltam. Mosás után (PBST 0,2) $200 \mu$ l szubsztrátoldatot (1,2 $\mathrm{mmol} / 1 \mathrm{H}_{2} \mathrm{O}_{2}$ és $3 \mathrm{mmol} / \mathrm{l}$ 1,2-fenilén-diamin (OPD) $200 \mathrm{mmol} / \mathrm{l}$ kálium-dihidrogén-citrátpufferban, pH 3,8) adagoltam. A szín kialakulása után (10 - 60 perc) az enzimreakciót $50 \mu \mathrm{l} 4 \mathrm{~N}$ $\mathrm{H}_{2} \mathrm{SO}_{4}$ reagenssel állítottam le. A színintenzitást az üregekben $492 \mathrm{~nm}$ hullámhosszon mértem. A mért értékekből a standard görbéket 4-paraméteres (szigmoid) egyenlettel készítettem. A detektálás alsó határa (LOD) az a koncentráció, amely a vakminta szórásának (3x ismétlés) háromszorosát adja. 


\subsection{Mintaelőkészítés}

\subsubsection{Búzaminták előkészítése DON méréshez}

GC-MS vizsgálattal igazolt (LOD 0,01 mg/kg) DON-mentes búzalisztet szennyeztem különböző koncentrációjú DON-nal 0-100 mg/kg koncentráció tartományban. A vizsgálathoz $1 \mathrm{~g}$ búzalisztet mértem ki, majd szennyeztem a megfelelő koncentrációjú DON oldattal. A mintákat $10 \mathrm{ml}$ acetonitril-víz 6:4 arányú keverékével hígítottam. A mintákat 10 percig kevertettem, majd hagytam ülepedni. A felülúszót méretkizárásos szürőn (Millipore Ultrafree-MC 50.000 NMWL) 10 percig 10000 fordulat/perc fordulatszámon centrifugáltam, majd a kapott szürleteket $4{ }^{\circ} \mathrm{C}$-on tároltam a felhasználásig.

\subsubsection{Ponty minták előkészítése Vtg méréshez}

A vizsgálathoz használt három hím és három nőstény ponty (Cyprinus carpio) az Aranyponty Zrt. (Rácegres, Rétimajor) ökológiai halgazdaságból származott. Az egyes egyedek vérmintáját 10 percig 6000 fordulat/perc fordulatszámon, majd 10 percig 11000 fordulat/perc fordulatszámon centrifugáltam.

A halakból vett májmintákat felaprítottam (Ultra-turrax, IKA, Németország), és 1 g mintát $10 \mathrm{ml} 42 \mathrm{mmol} / \mathrm{l} \mathrm{pH}$ 7,4-es TRIS pufferben homogenizáltam. A mintákat vákuumcentrifugáltam 20 percig 4000 fordulat/perc fordulatszámon, majd ezt követően ismét 10 percig 12000 fordulat/perc fordulatszámon centrifugáltam. A minták felülúszóját $4{ }^{\circ} \mathrm{C}$-on tároltam a felhasználásig.

\subsubsection{Béka minták előkészítése Vtg méréshez}

A vizsgálatokhoz európai vöröshasú unkát (Bombina bombina) alkalmaztam. Tekintettel arra, hogy minden hazai békafaj védett, ezért a Természetvédelmi Felügyelöség engedélye alapján a természetből begyüjtött petecsomókból laboratóriumi tenyészetben nevelt vöröshasú unkát használtam. A fiatal egyedekből vett máj-, szív- és ivarmirigymintákat (Double Delta Kft.) ugyanúgy dolgoztam fel, ahogy azt a pontyminták esetében (lsd. 4.3.2. fejezet).

\subsection{Alkalmazott számítástechnikai és statisztikai módszerek}

Az eredmények ábrázolásához, valamint statisztikai értékeléséhez az EXCEL (Microsoft Office professional Edition 2003) és az ORIGIN Scientific Graphing and Analysis Software (version 7) statisztikai programot használtam. Az eredmények összehasonlításához a Student-féle kétmintás t-próbát alkalmaztam $\mathrm{p}<0,05$ szignifikanciaszintet alkalmazva. 


\section{EREDMÉNYEK}

\subsection{A szenzorválasz vizsgálata modellkísérletekkel}

A mérések során a hullámvezető felszínén kialakított minden egyes réteg módosítja annak optikai és kémiai tulajdonságait. Annak érdekében, hogy megértsem az OWLS-sel történő érzékelés alapjait, valamint azt, hogy a vizsgálat során kialakított rétegek, és a felülettel kapcsolatba kerülö anyagok (minta, puffer stb.) hogyan változtatják meg az optikai tulajdonságokat, illetve, hogy bebizonyítsam, a felületmódosítási és rögzítési lépések a mérések során reprodukálhatóak, vizsgáltam a szenzor felületén kialakuló rétegek vastagságát, a szenzorválaszt az analitikum molekulatömege és koncentrációja függvényében, a szenzorválasz reakcióidejét, a mérés pontosságát, és a különböző vastagságú küvetták alkalmazásának mérésre gyakorolt hatását. E modellkísérletek eredményei alapul szolgáltak az immunszenzor fejlesztésekhez. A fehérje koncentráció és szenzorválasz közti korreláció alapján az OWLS szenzort a továbbiakban immunanalitikai eljárások fejlesztésére alkalmaztam.

\subsubsection{Különböző fehérjék rögzítése során kialakult rétegvastagságok vizsgálata}

Kísérleteimben különböző fehérjéket (hirudint, tripszin inhibítort, ovalbumint, marha szérum albumint, glükózoxidázt, $\gamma$-globulint és hemocianint) rögzítettem a szenzor felületére glutáraldehiddel, és vizsgáltam az egyes fehérjék rögzítése során kialakult rétegvastagságot. A kísérletben OW 2400-as kezeletlen chipeket használtam. Az immobilizálási protokoll végrehajtása során a rétegvastagság változása becsülhető, csak közelítő értékek határozhatóak meg. A kezeletlen szenzor hullámvezető rétegvastagsága 170-200 nm közt volt. A vizsgálatban a szenzor felületét 3-amino-propil-trietoxi-szilánnal (APTS) módosítottam. Tíz chipet vizsgálva az átlagos rétegvastagság változás APTS-sel történő módosítást követően, desztillált víz áramoltatás mellett

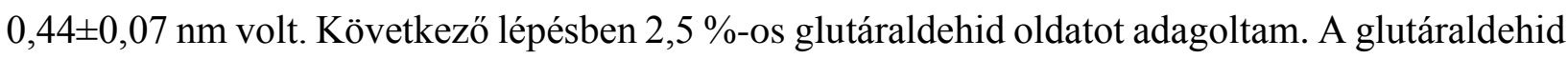
átlagosan $0,27 \pm 0,07 \mathrm{~nm}$ rétegvastagság növekedést okozott. A keresztkötő molekula hozzáadása után a desztillált vizet lecseréltem a méréshez használatos 42 mM-os pH=7,4 TRIS pufferre. A TRIS puffer hatására a jel megváltozott, azonban itt nem a rétegvastagság növekedett, hanem az oldat törésmutatója (nc) változott, ez okozta a jeleltolódást. Ebben az esetben új modellel kell tovább számolni, ezért igen fontos a mérések előtt az adott pufferrel az alapvonal felvétele. A TRIS alapvonal beállását követően injektáltam a $0,1 \mu \mathrm{M}$-os fehérjeoldatokat. A négyrétegü hullámvezető linearizált módusegyenletével a két módusra mért effektív törésmutató alapján kiszámítható az adszorbeált réteg törésmutatója és vastagsága, melyből meghatározható az egységnyi felületre adszorbeálódott anyag tömege (lsd. 2.3.1. fejezet). Azonban az eredményeim 
ismertetésekor az ábrákon nem a ng/ $\mathrm{cm}^{2}$ mértékegységet tüntettem fel, hanem az „egység”-et (arbitrary unit, a.u.), mivel a három- és négyrétegű modellekkel történő tömegszámítás elsősorban a felületen adszorbeálódott molekulák tömegének meghatározására alkalmas. Kísérleteimben többrétegü modellekkel dolgoztam. Az alkalmazott rögzítési módtól függően a meghatározandó fehérje a szenzor felületén az ötödik vagy hatodik réteg volt, ezért nem bizonyított, hogy a mért (látszólagos) tömegváltozás tényleg megfelel a szenzor felületén kötődő molekulák tömegének. Ez azonban nem befolyásolta az eredményeimet, mert minden esetben alkalmaztam standard oldatokat a kalibrációhoz, illetve a minták értékeléséhez.

\subsubsection{Szenzorválasz vizsgálata az analitikum molekulatömege és koncentrációja függvényében}

Ahhoz, hogy megállapítsam, hogy az analitikum molekulaméretétől hogyan függ a válaszjel nagysága különböző molekulatömegü, de azonos molaritású $(0,1 \mu \mathrm{M})$ fehérjeoldatokat immobilizáltam. A szenzor felületén glutáraldehiddel kovalensen rögzítettem a fehérjéket. Modellfehérjeként hirudint (MW 7000 Da), tripszin inhibítort (MW 20100 Da), ovalbumint (OVA, MW 45000 Da), marha szérum albumint (BSA, MW 66000 Da), glükózoxidázt (GOx, MW 160000 Da), $\gamma$-globulint (MW 175000 Da) és hemocianint (KLH, MW 6000000 Da) alkalmaztam. A molekulatömegüket poliakrilamid gélelektroforézissel (SDS PAGE) is ellenőriztem (8. ábra).

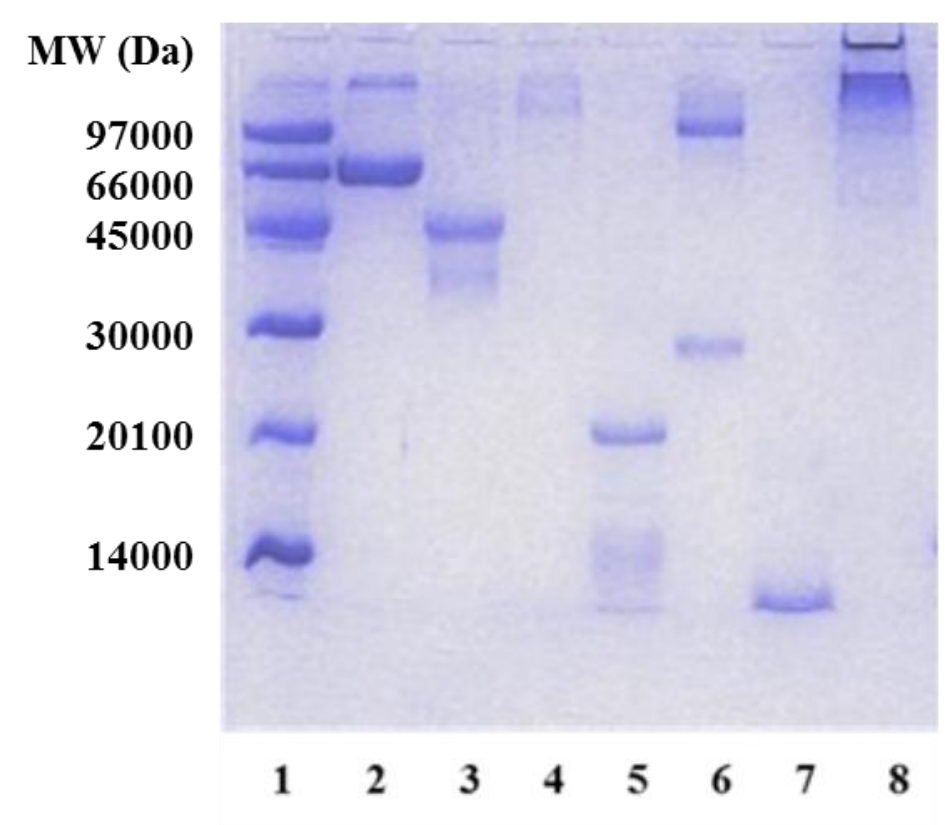

8. ábra Különböző molekulatömegü fehérjék elválasztása poliakrilamid gélelektroforézissel (1: molekula standard, 14000-97000 Da, 2: BSA, 3: OVA, 4: GOx, 5: tripszin inhibítor, 6: $\gamma$-globulin, 7: hirudin, 8: KLH) 
A fehérjék immobilizálása során a molekulatömegtől függően a rétegvastagság változása $0,02-$ 1,25 nm között volt. A szenzor felületén immobilizált fehérjék molekulatömege és az OWLS szenzor válaszjele közti korrelációt a 9. ábra mutatja be. Az eredmények szerint, hacsak nincs különbség a kötődési tulajdonságokban, akkor a szenzorválasz nagysága egyenesen arányos a molekulatömeggel.

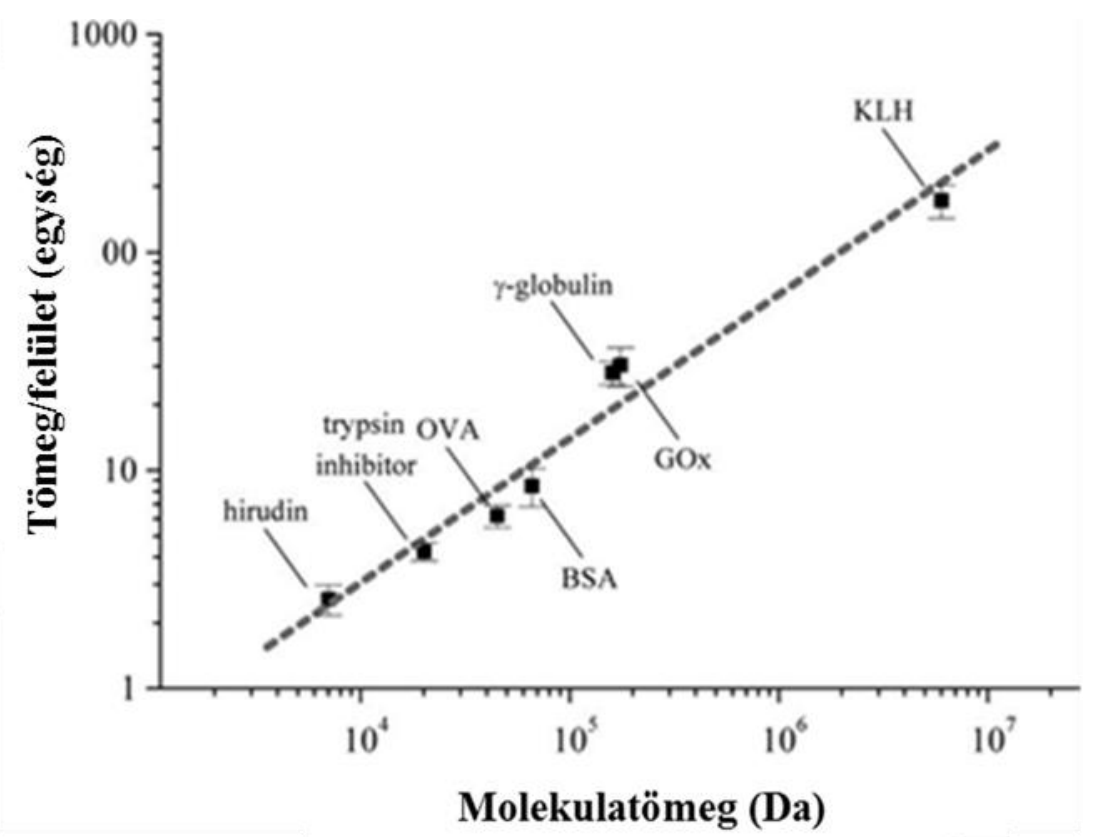

9. ábra A szenzor felületén immobilizált fehérjék molekulatömege és az OWLS szenzor válaszjele közti korreláció.

Szintén vizsgáltam, hogy hogyan változik a szenzorválasz nagysága egy adott fehérje különböző koncentrációban történő rögzítésekor. A vizsgálatban az aminoszilanizált szenzor felületére BSA-t rögzítettem glutáraldehiddel 0,005-0,8 $\mu \mathrm{M}$ koncentrációtartományban a korábban leírt módon. A kísérletben a szenzorválasz nagysága lineárisan nőtt a BSA koncentráció növekedésével $\left(\mathrm{r}^{2}=0,971\right)$ (10. ábra). 


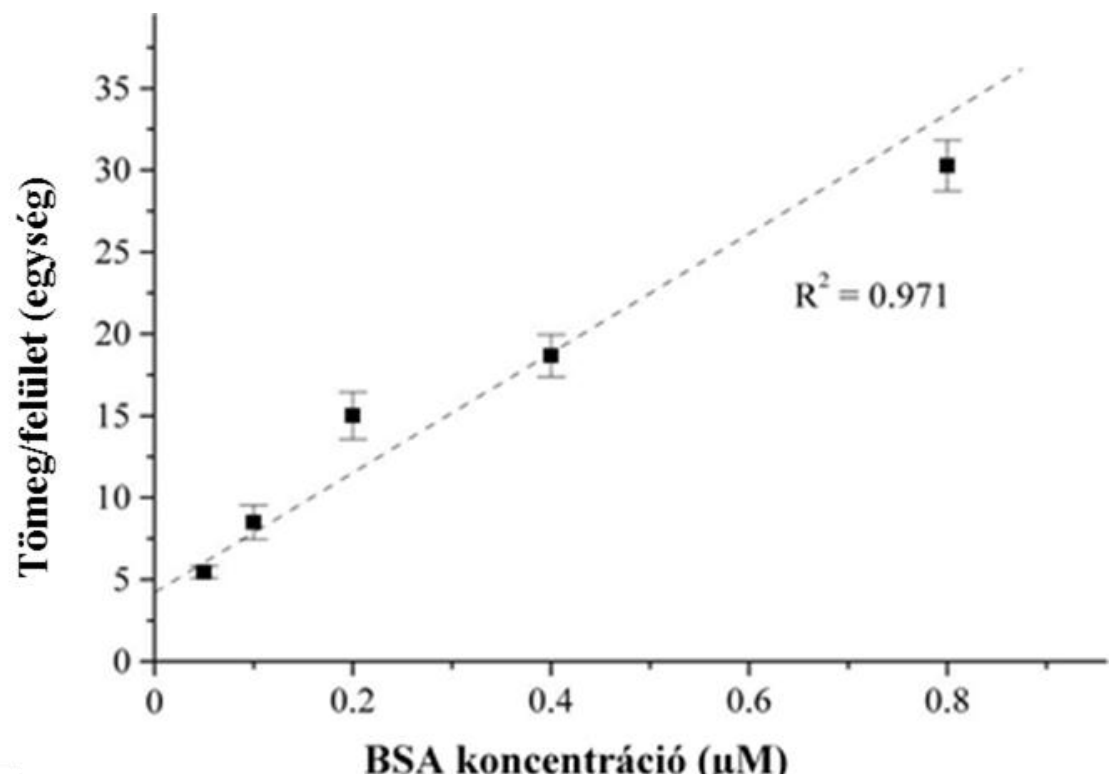

10. ábra A szenzor felületén immobilizált fehérjék koncentrációja és az OWLS szenzor válaszjele közti korreláció.

\subsubsection{Szenzorválasz reakcióideje és a mérés pontossága}

Az OWLS készülékben a fényforrás egy lineárisan polarizált He-Ne lézer (632,8 nm). A lézerfény a küvettában található chipre merölegesen érkezik. A szenzortartó a számítógép által vezérelt léptető motor segítségével meghajtott mikrométercsavarral forgatható a lézer felett. A becsatolási szögeket $-5^{\circ}$ és $5^{\circ}$ közti tartományban forgatva vizsgáltam. A léptető motor egy körben 1000 lépést tesz meg. Egy lépés alatt a mikrométer csavar 0,0005 mm-t mozdul, ennek megfelelően a legkisebb vizsgálható szöglépés $0,000286^{\circ}$. A vizsgálatok indításánál minden chip karakterisztikus $\alpha_{\mathrm{TE}}$ és $\alpha_{\mathrm{TM}}$ csúcsait meg kell határozni. A kezdeti $\alpha_{\mathrm{TE}}$ és $\alpha_{\mathrm{TM}}$ csúcsok meghatározásához $0,01^{\circ}$ és $0,02^{\circ}$ fokonkénti szöglépést alkalmaztam, ugyanakkor a reakciók vizsgálatnál, a törésmutató mérési módban már elegendő a $0,02^{\circ}$ vagy $0,05^{\circ}$ léptetést alkalmazni. Így az OWLS technikával az alkalmazott beállítási protokolltól függően percenként 4-10 mérési pont felvétele lehetséges, azaz az adott szögtartományban legalább 6 másodperc szükséges egy mérési pont meghatározáshoz. Kémiai, biokémiai reakciók sebességének meghatározásához az ilyen sebességű adatszolgáltatás megfelelő, hogy a technikát valós idejü méréstechnikának lehessen tekinteni. Egy immobilizációs reakció a szenzor felületén kb. 2-10 percet vesz igénybe reakciótípustól függően. A fent említett adatszolgáltatási sebességgel az egyensúlyi állapot kialakulása jól monitorozható. 
Az érzékelés pontosságát nagyban befolyásolja, hogy a mérés során az olyan chip, amelynek felületén semmilyen felületi módosítás nem történt, annak a $\alpha_{\mathrm{TE}}$ és $\alpha_{\mathrm{TM}}$ becsatolási szöge az alapvonal felvételénél milyen variabilitást mutat. A kísérletben OWLS szenzor chipeket vizsgáltam szárazon, puffer áramoltatása nélkül. A mérést egy percig végeztem majd vizsgáltam az $\alpha$ TM és az $\alpha$ TE adatok változását. Átlagosan az $\alpha_{\mathrm{TM}}=0,724627 \pm 0,0000824$ (relatív hiba 0,011\%), míg a $\alpha_{\mathrm{TE}}=3,197883 \pm 0,000157$ (relatív hiba 0,005\%). Természetesen, ha a felületen bármilyen molekuláris kölcsönhatás létrejön, a becsatolási szög eltolódik. Vizsgálatom során kb. $0,005^{\circ}$ $0,01^{\circ}$ eltérést tapasztaltam.

Vizsgálataimban külön figyelmet fordítottam a mérési körülmények, különös tekintettel a hőmérséklet állandó szinten tartására. A szenzor felületének hőmérsékletét a szenzortartóhoz csatlakoztatott hőmérséklet szabályzó egységgel (OWLS TC) tartottam állandó értéken. A szabályzó egység képes a beállított hőmérsékletet $\pm 0,1^{\circ} \mathrm{C}$-os pontossággal tartani.

\subsubsection{Különböző méretű küvetták alkalmazásának mérésre gyakorolt hatása}

A szenzort a mérőberendezés mintatartó átfolyó cellájába (küvetta) helyezve használtam. A szenzor felett elhelyezkedő küvetta tömítése az üveg chiphez a küvetta kialakításának megfelelően ovális gumigyürüvel történik. A küvetta biokompatibilis poliéter-éter-keton (PEEK) anyagból készült, a folyadék ki-be vezetésére teflon- vagy PEEK csövek szolgáltak. Kísérletem célja az volt, hogy megvizsgáljam a készülékhez tartozó különböző méretű küvetták használatával, hogyan változik a szenzorjel nagysága. A vizsgálathoz 0,8 és $0,3 \mathrm{~mm}$ mélységü küvettákat használtam. A kísérletet aminoszilanizált chipekkel végeztem, mintaként BSA/anti-BSA modell molekulapárt használtam. A chip felületén 2,5\%-os glutáraldehiddel $20 \mu \mathrm{g} / \mathrm{ml} \mathrm{BSA-} \mathrm{t} \mathrm{rögzítettem}$ és mintaként különböző koncentrációjú anti-BSA-t (500-szoros, 1000-szeres, 2000-szeres, 4000szeres hígításban) injektáltam és vizsgáltam a válaszjel nagyságát. A vizsgálatot $120 \mu \mathrm{l} / \mathrm{min}$ áramlási sebességnél $24,5^{\circ} \mathrm{C}$-on termosztálva végeztem. Méréseim alapján megállapítottam, hogy a 0,3 mm mélységü küvettával sokkal nagyobb válaszjeleket kapok ugyanolyan koncentrációjú minta injektálásakor, mint a 0,8 mm mélységű küvetta alkalmazásával. Ez azzal magyarázható, hogy az injektált $200 \mu$ mennyiségü minta sokkal hosszabb ideig tartózkodik a szenzor felületén a küvetta kisebb térfogata miatt, mint a 0,8 mm mélységű küvetta esetében. 


\subsection{DON meghatározására alkalmas immunszenzor fejlesztése}

\subsubsection{A szenzorfejlesztéshez szülkséges immunanyagok előállítása}

A vizsgálandó anyagok immunanalitikai meghatározásához előállítottam az antigének fehérjékhez kötött immunogénjeit, majd az immunogénekkel nyulakat immunizáltam. A poliklonális antitestet tisztítottam, ellenőriztem. Mivel a kisméretű (10 kD alatti móltömegü) molekulák önálló immunogén hatással nem rendelkeznek, vagyis a gerincesek szervezetébe bejutva nem tudnak humorális immunválaszt indukálni (az állatszervezet legfeljebb toxikus válaszreakciókat adhat, de antitestek termelésével nem válaszol a bejuttatott idegen anyagra), a célvegyületeket kellő méretü hordozómolekulához (fehérjékhez) kellett kapcsolni, hogy az immunizálás sikeres legyen, s a célvegyületekre specifikus antitesteket nyerhessek.

\subsubsection{DON konjugátum szintézise}

DON vizsgálatához kétféle konjugátumot készítettem: ovalbuminhoz (OVA) és BSA-hoz kötöttet. A kötés létrehozásához mind a fehérjéket, mind a DON-t elő kellett készíteni.

A fehérjék előkészítéséhez a fehérjékből 1-1 mg mennyiséget vettem, melyhez 0,24 ml desztillált vizet adtam és $0,06 \mathrm{ml}$ nátrium-perjodátot $(0,1 \mathrm{M}, 10 \mathrm{mM}$ nátriumfoszfátban) adagoltam a fehérjék aktiválásához. Az elegyet 20 percig rázattam, majd dialízis membránba töltöttem, és hüvös helyen 1 napig, $1 \mathrm{mM}$ nátrium-acetátban dializáltam, hogy a felesleges nátrium-perjodátot eltávolítsam.

A DON előkészítéséhez 3 mg DON-hoz $30 \mu \mathrm{l}$ acetonitrilt és $30 \mu \mathrm{l}$ ecetsavanhidridet (4\%, acetonitrilben) adtam. Katalizátorként 4-dimetil-amino-piridint adagoltam, és az egészet 1 óráig kevertettem. Az egy óra elteltével $50 \mu 1$ metanollal még egy pár percig kevertettem. Az előkészített fehérjékhez 36,6 $\mu 1$ a fentiek szerint előkészített DON-t adtam, és két óráig kevertettem. Két óra elteltével $20 \mu \mathrm{l}$ 4\%-os nátrium borohidridet adtam, hogy a reakciót leállítsam, és még két órát kevertettem. A két óra elteltével mindkét konjugátumot gélszürőn tisztítottam.

A tisztított DON-BSA konjugátum $0,256 \mathrm{mg} / \mathrm{ml}$ fehérjét tartalmazott, míg a DON-OVA fehérjetartalma 5,31 mg/ml volt Bradford (1976) módszere alapján (1sd. 4.2.5. fejezet).

\subsubsection{Fehérjefrakciók ellenörzése izoelektromos fókuszálással}

Annak bizonyítására, hogy a kapott fehérjefrakciók a fehérje-DON konjugátumot tartalmazták, a fehérjéket izoelektromos pont alapján szeparáltam karbamidot tartalmazó poliakrilamid gélben a 4.2.7. fejezetben ismertetett módszer szerint. A futtatási képen látható (11. ábra), hogy a felvitt standard mintáktól jól elkülönül a BSA konjugátum 1. frakció és az OVA konjugátum 1. frakció, ami azt jelenti, hogy ezek a frakciók valóban tartalmazták a fehérje-DON konjugátumot. 


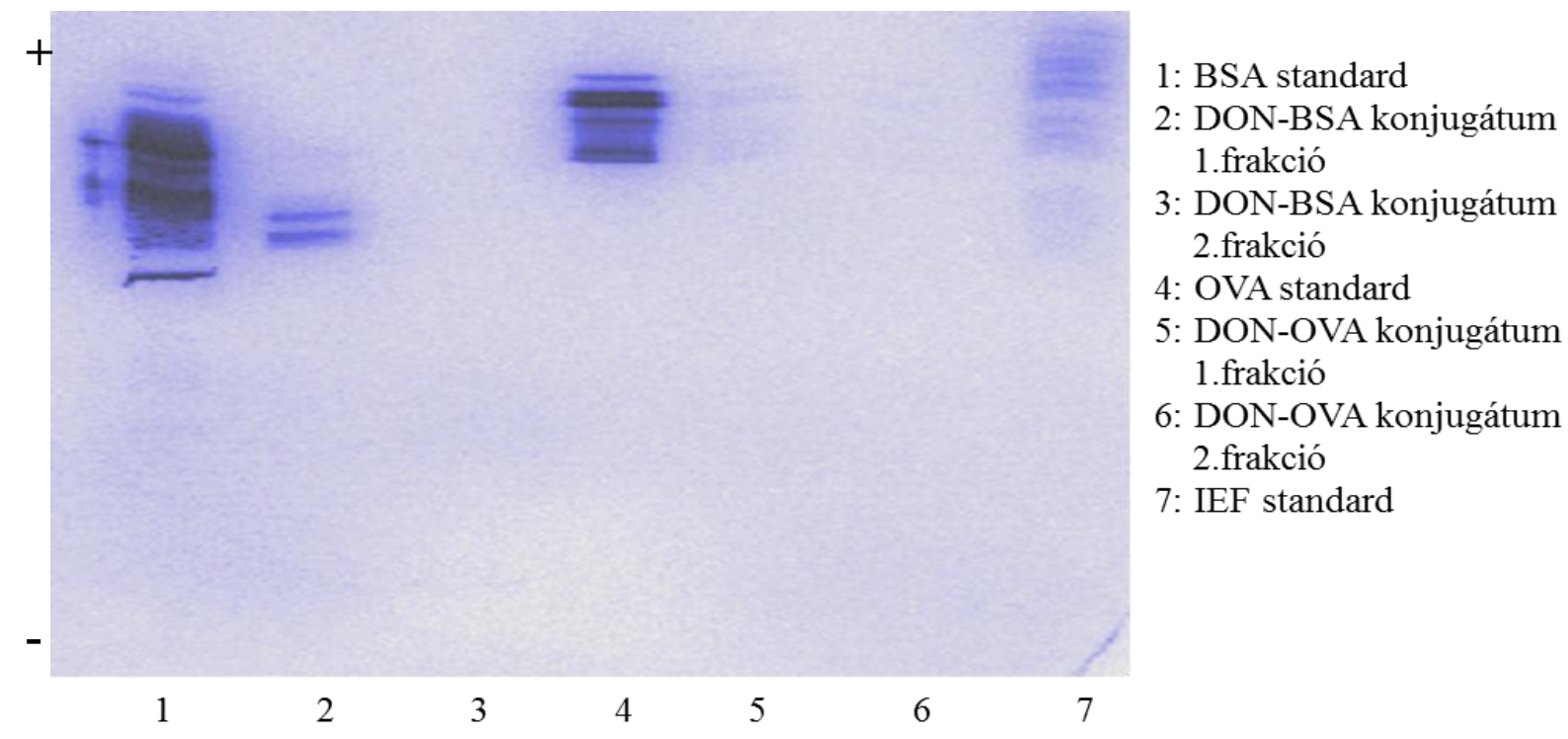

11. ábra: DON-fehérje konjugátumok izoelektromos pont alapján tötrénő szeparálása karbamidot tartalmazó poliakrilamid gélben

\subsubsection{DON specifikus antitestek elöállítása}

A DON antigénre specifikus nyúlszérumot magyar vadas óriásnyúlban történő immunizálással, Harboe és Inglid (1973) módszerét adaptálva állítottam elő. Az immunizálás kis molekulatömegü antigén esetén az antigén konjugátumával történt. Az alapimmunizálás Freundkomplett adjuvánssal, míg az emlékeztető immunizálások Freund-inkomplett adjuvánssal történtek. A tisztított antigénkonjugátumot $1 \mathrm{mg} / \mathrm{ml}$ koncentrációban $0,01 \mathrm{~mol} / 1$ foszfáttal pufferolt sóoldatban (PBS) (pH 7,4) oldottam fel. A 0., 14., 28. és 42. napon a kb. 3,2 kg tömegü nyulakat $25 \mu \mathrm{g}$ antigén/testömeg $\mathrm{kg}$ koncentrációjú antigén (DON-ovalbumin konjugátum) oldattal (50 $\mu$ l fiziológiás sóoldat és $50 \mu$ komplett/inkomplett Freund adjuváns) immunizáltam lapocka közötti, többszöri injektálással. A kontrolszérumok immunizálás elött, illetve az immunszérumok a marginális vénából, 8-10 nappal az emlékeztető oltások után lettek levéve.

\subsubsection{DON antigénspecifikus tisztított IgG elöállítása}

Az immunszérumokat IgG-re tisztítottam Harbo and Inglid (1973) leírata szerint. Első lépésként a nyúlszérumból kisózásos módszerrel tisztított $\mathrm{IgG}$-frakciót állítottam elö. Tíz ml nyers immunszérumhoz lassú kevertetés mellett $10 \mathrm{ml} \mathrm{70 \% -os} \mathrm{ammónium-szulfát} \mathrm{oldatot} \mathrm{adtam}$ szobahőmérsékleten. A pH-t ammóniával ( $\mathrm{pH} 7,0)$ állítottam be. A kevertetést két óráig folytattam, majd a szuszpenziót lecentrifugáltam (20 perc, $2500 \mathrm{rpm}$ ). A csapadékot $5 \mathrm{ml}$ 0,01 M PBS-ben (pH 7,4) újraoldottam, és $5 \mathrm{ml}$ 70\%-os ammónium-szulfát-oldatot adtam hozzá. Ezután a szuszpenziót ismét 2 órán át kevertettem szobahőmérsékleten, centrifugáltam az előbbiek szerint, 
és a felülúszót dekantáltam a csapadéktól, mivel a szupernatáns albuminokat, transzferrint, $\gamma$ mobilitású fehérjéket (pl. haptoglobulin, szabad hemoglobin) is tartalmaz. A specifikus immunglobulinokat is tartalmazó nyúl IgG-frakcióból álló csapadékot $5 \mathrm{ml}$ foszfát pufferben feloldottam és $10 \mathrm{~mm} \times 21 \mathrm{~mm}$ dializáló zsákba töltöttem. A dialízist $4{ }^{\circ} \mathrm{C}$-on $2 \times 12$ óráig $\mathrm{kb}$. 20 térfogatnyi foszfát pufferrel szemben végeztem. A tisztított szérumokat mélyhütőben tároltam.

\subsubsection{DON specifikus antitestek antigénnel szembeni aktivitásának vizsgálata}

A kialakított nyúlszérumok antigénnel szembeni aktivitását indirekt ELISA módszerrel vizsgáltam. A polisztirol alapú mikrotiterlemez mérőhelyeit $100 \mu \mathrm{l} / \mathrm{lyuk} 5 \mu \mathrm{g} / \mathrm{ml}$ DON-OVA tartalmú ( $0,1 \mathrm{M}$ karbonát-bikarbonát, $\mathrm{pH} 9,6)$ oldattal, $4{ }^{\circ} \mathrm{C}$-on egy éjszakán át történő inkubálással érzékenyítettem. A lemezeket háromszor átmostam $250 \mu 1 / 1 y u k$ mosópufferrel $(0,1 \%$ Tween 20 tartalmú 0,01 M PBS, pH 7,4), majd a szabad kötőhelyeket $200 \mu 1$ /lyuk 5 \% zselatin tartalmú PBSben blokkoltam $\left(37^{\circ} \mathrm{C}, 1\right.$ óra). Az ismételt mosást követően $100 \mu 1 / 1 y u k$ DON-OVA ellen nyúlban termeltetett ellenanyagot hígítási sorban lekötöttem. Újabb mosást követően a kialakult immunkomplex detektálására a lemezeket $100 \mu$ 1/lyuk torma-peroxidázzal jelölt anti-nyúl kecske IgG konjugátummal inkubáltam (30000-szeres hígításában, $37{ }^{\circ} \mathrm{C}, 1$ óra). Ismételt mosást követően a színkialakítást $100 \mu \mathrm{l} /$ lyuk szubsztrát és kromogén tartalmú $\left(\mathrm{OPD} / \mathrm{H}_{2} \mathrm{O}_{2}\right)$ oldattal történő inkubálással (20 perc, szobahőmérsékleten) végeztem. A reakciót $50 \mu 1 / 1 y u k 3 \mathrm{M} \mathrm{H}_{2} \mathrm{SO}_{4}$ oldattal állítottam le. Az optikai denzitás abszorbancia értékeit $490 \mathrm{~nm}$-en automata ELISA fotométerrel mértem.

A két nyúlból származó szérum fehérje tartalma (A, B) $127.0 \mathrm{mg} / \mathrm{ml}$ és $116.2 \mathrm{mg} / \mathrm{ml}$ volt, míg a tisztított szérumoké (A tiszt., B tiszt.) 31,8 mg/ml és 39,2 mg/ml volt. A szérumok és az IgG frakciók ELISA-val történő ellenőrzésének titrálási görbéit a 12. ábra mutatja be. Az ellenőrző ELISA mérés alapján a két szérum hasonló eredményt adott, mindkét szérum esetén még a nagy hígításoknál (640-szeres és 1280-szoros) is stabil jelet adott. Ugyanakkor a B szérum nagyobb érzékenységet mutatott, ezért az abból tisztított (B tiszt.) szérummal dolgoztam a továbbiakban. 


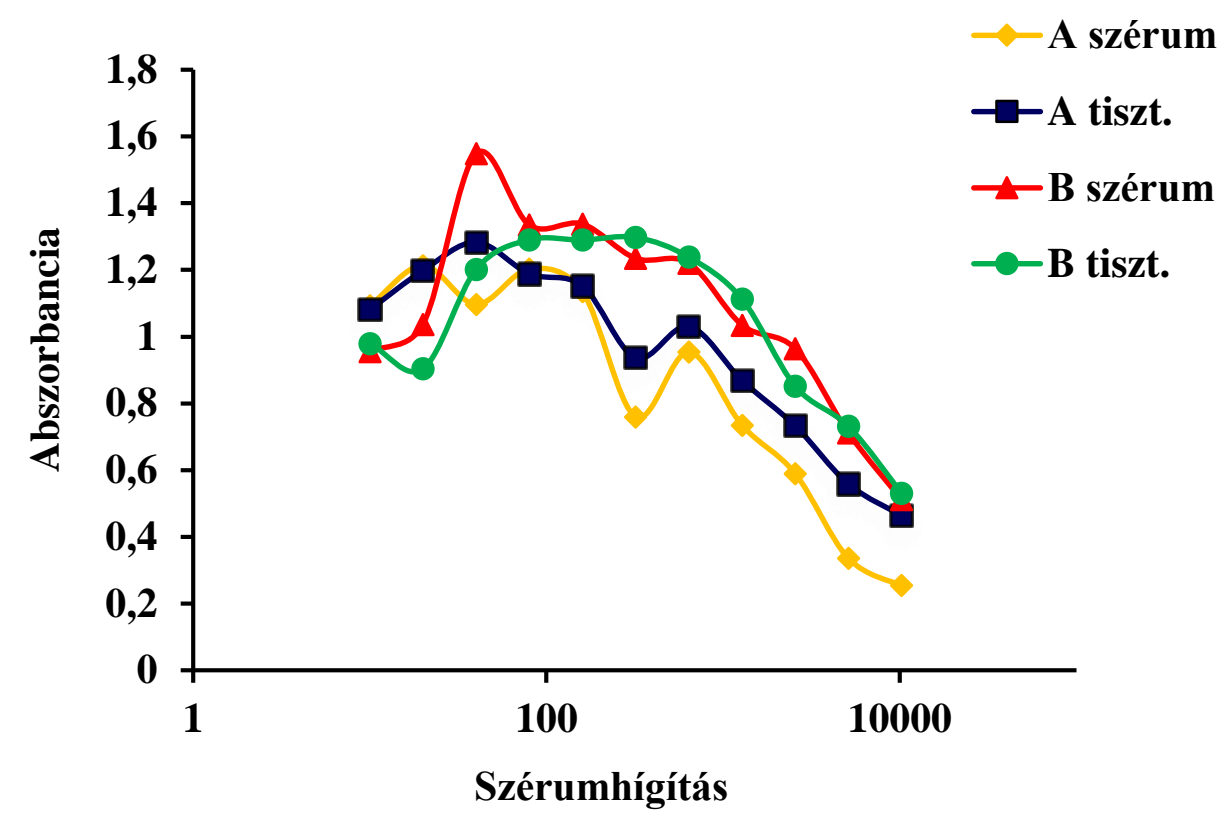

12. ábra Az anti-DON szérum és az IgG frakciók ellenőrzése indirekt ELISA módszerrel

\subsubsection{Immunszenzor fejlesztés DON kimutatására}

Munkám következő részében az immunszenzorok fejlesztését kezdtem meg az elkészített antitestek segítségével. A szenzorfejlesztésnél két különbözö, direkt (nem-kompetitív) illetve indirekt (kompetitív) immunszenzor kialakítását vizsgáltam. A nem-kompetitív vagy "direkt" szenzor (13. ábra) esetében a hullámvezető felületén a nyulakban termeltetett specifikus poliklonális szérum megfelelő hígítású oldatát rögzítettem kovalens kötésekkel, és közvetlenül mértem a kimutatandó vegyületeket tartalmazó standardokra, illetve mintákra adott szenzorválaszok nagyságát.



13. ábra Nem-kompetitív immunszenzor elve 
A kompetitív (,,indirekt”) immunszenzor (14. ábra) kifejlesztése során a vizsgálandó antigén, illetve az antigén fehérjével képzett konjugátuma került rögzítésre. A mérések során a standard oldatokat, illetve mintákat ismert mennyiségü antitestet tartalmazó poliklonális szérummal kevertem össze, meghatározott ideig inkubáltam, majd injektáltam az áralmó rendszerbe. A mérésnél így indirekt úton az antigének által meg nem kötött, szabad antitestek mennyiségét határoztam meg, és ebből a jelből következtettem a minták antigén tartalmára.

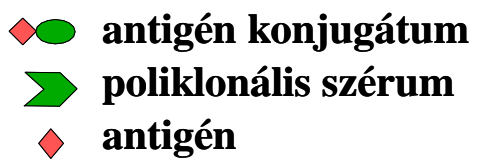

\section{poliklonális szérum + minta}
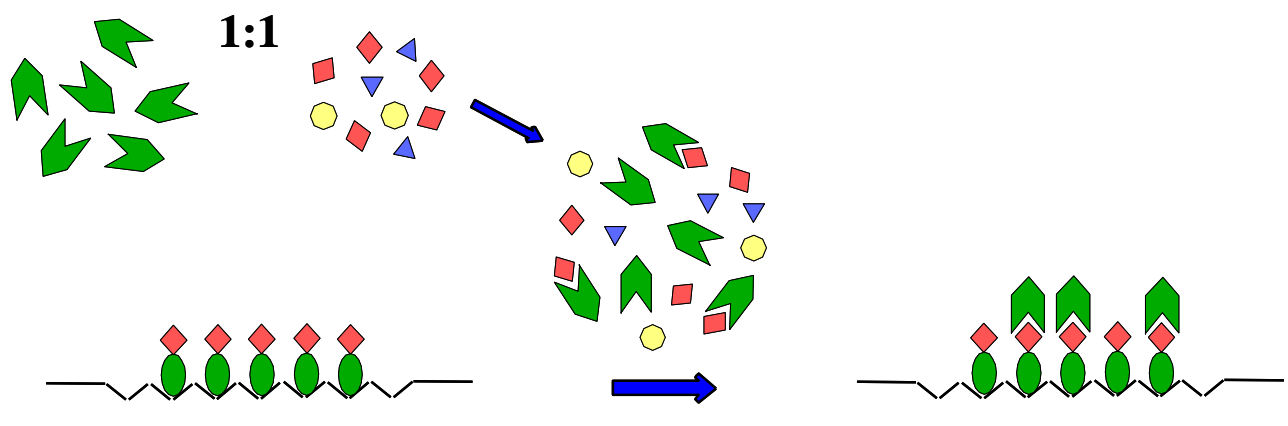

14. ábra Kompetitív immunszenzor felépítése

\subsubsection{Szenzor felületének módosítása és fehérjék immobilizációja}

A vizsgálathoz OW2400 típusú integrált optikai hullámvezető szenzort használtam, melynek felületét APTS-sel módosítottam a 4.2.2 fejezetben leírtak szerint. E szenzor felületére rögzítettem kovalensen a direkt immunszenzor kialakításánál a DON ellen termelt antitestet, míg a kompetitív immunszenzor fejlesztésénél a DON-BSA konjugátum került rögzítésre. A biomolekulák rögzítését glutáraldehiddel végeztem a 4.2.4 fejezet alapján.

\subsubsection{Direkt immunszenzor DON kimutatására}

Kísérleteimben DON direkt mérési módszerrel történő kimutatásának lehetőségét vizsgáltam, ahol a szenzor felületére DON specifikus poliklonális szérumot rögzítettem és az antigén (DON) antitesthez való kötődése által indukált válaszjeleket értékeltem. A direkt mérési módszernél az érzékenységet a szenzor felületére rögzített antitest mennyisége határozza meg. Annak érdekében, hogy meghatározzam az immobilizálandó szérum megfelelő mennyiségét, a szenzor felületén különböző koncentrációban rögzítettem a DON specifikus antitestet, és 
vizsgáltam a különböző koncentrációjú standardra (0,1-100000 ng/ml) adott válaszjelek nagyságát. A legjobb eredményeket az antitest $8 \mu \mathrm{g} / \mathrm{ml}$ koncentrációban történő rögzítésével értem el. A 15. ábra az így kialakított direkt immunszenzorral felvett kalibrációs görbét mutatja be.

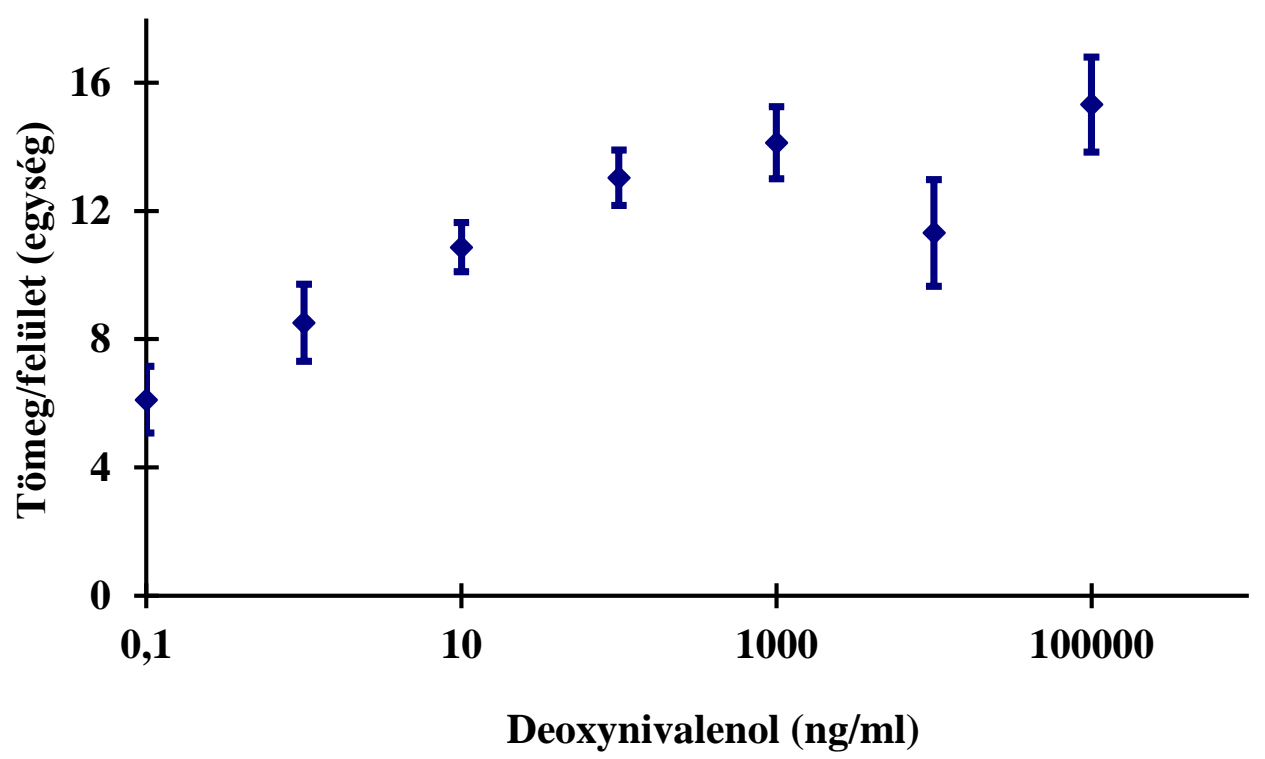

15. ábra DON direkt mérés kalibrációs görbéje ( $8 \mu \mathrm{g} / \mathrm{ml}$ antitest rögzítésével)

A kalibrációs görbe alapján a DON koncentrációjától függő jeleket csak a 0,1-100 ng/ml koncentrációtartományban kaptam. Nagyobb koncentrációjú DON standardok injektálásával nem kaptam szignifikáns jelnövekedést, mert a felület gyorsan telítődött. A szenzor kis érzékenysége azonban nem meglepő a direkt mérési módszernél, mert a felületre rögzített antitest molekula tömege jóval nagyobb ( $\approx 180000 \mathrm{Da})$, mint az analitikumé (DON $\approx 296,32)$, így a DON kötődése relatíve kisebb tömegváltozást jelent a szenzor felületén, mint amit az antitest kötődése okozna. Ugyanakkor az evanescens térben egyre csökken az adott tömegre adott jel nagysága, ezért is ilyen kicsik a jelek. Az általam kifejlesztett direkt mérési mód érzékenysége DON kimutatására nem volt megfelelő, ezért az élelmiszerekből történő DON kimutatását nem teszi lehetővé.

\subsubsection{Kompetitív immunszenzor fejlesztése DON meghatározásra}

Aminoszilanizált szenzor felületen DON detektálására alkalmas indirekt immunszenzort fejlesztettem, feltételezve, hogy ezzel az eljárással nagyobb érzékenységet érhetek el, mint a direkt szenzorok esetében. A szenzorok kialakítása során a DON-BSA konjugátumot aminofunkcionalizált felületen 2,5\%-os glutáraldehiddel két lépésben rögzítettem a szenzor felületén. A mintákat illetve standardokat 1:1 arányban kevertem a megfelelö koncentrációjú antitestekkel majd kontrollált körülmények közt inkubáltam és injektáltam a rendszerbe. 


\subsection{Poliklonális antitest mennyiségének meghatározása}

A kompetitív szenzor fejlesztésekor a legfontosabb optimalizálandó paraméterek a szenzorfelületen rögzített DON-BSA konjugátum koncentrációja, valamint az alkalmazott poliklonális szérum hígításának mértéke volt. A kísérletek során, a szenzor felületén $512 \mathrm{ng} / \mathrm{ml}$ DON-BSA konjugátumot rögzítettem glutáraldehiddel és a különböző koncentrációban injektált szérumok $(63,6 \mu \mathrm{g} / \mathrm{ml}, 15,9 \mu \mathrm{g} / \mathrm{ml}, 8 \mu \mathrm{g} / \mathrm{ml}, 6,4 \mu \mathrm{g} / \mathrm{ml}, 3,2 \mu \mathrm{g} / \mathrm{ml}, 2,5 \mu \mathrm{g} / \mathrm{ml}$,) válaszjelét vizsgáltam. A mérés során az áramlási sebesség $120 \mu 1 /$ perc volt, míg a szenzortartó küvetta hőmérsékletét $24,5{ }^{\circ} \mathrm{C}$-on termosztáltam. Ahogy a 16 . ábrán is látható, $3,2 \mu \mathrm{g} / \mathrm{ml}, 2,5 \mu \mathrm{g} / \mathrm{ml}$, koncentrációjú antitest injektálásával a szenzorválaszok közel azonosak, a görbék lefutása bizonytalan. A mért szenzorválaszok 21,46 $\pm 0,48,18,13 \pm 0,6,17,05 \pm 0,89$ egységek voltak. Kis szérumhígítás esetén $(63,6 \mu \mathrm{g} / \mathrm{ml})$ a szérum által adott válaszjel elválik a többi görbétől, túl nagy jelet ad, a szenzorválasz 68,4 $\pm 0,8$ egység. Azt a szérumhígítást kell választani, ahol az antitestek éppen telítik a szenzor felületét, a szenzorválasznál már kismértékü lemosódás tapasztalható, a görbének van platója. A görbe alakját és nagyságát figyelembe véve a DON kompetitív méréséhez a továbbiakban $8 \mu \mathrm{g} / \mathrm{ml}$ koncentrációban alkalmaztam a poliklonális szérumot.

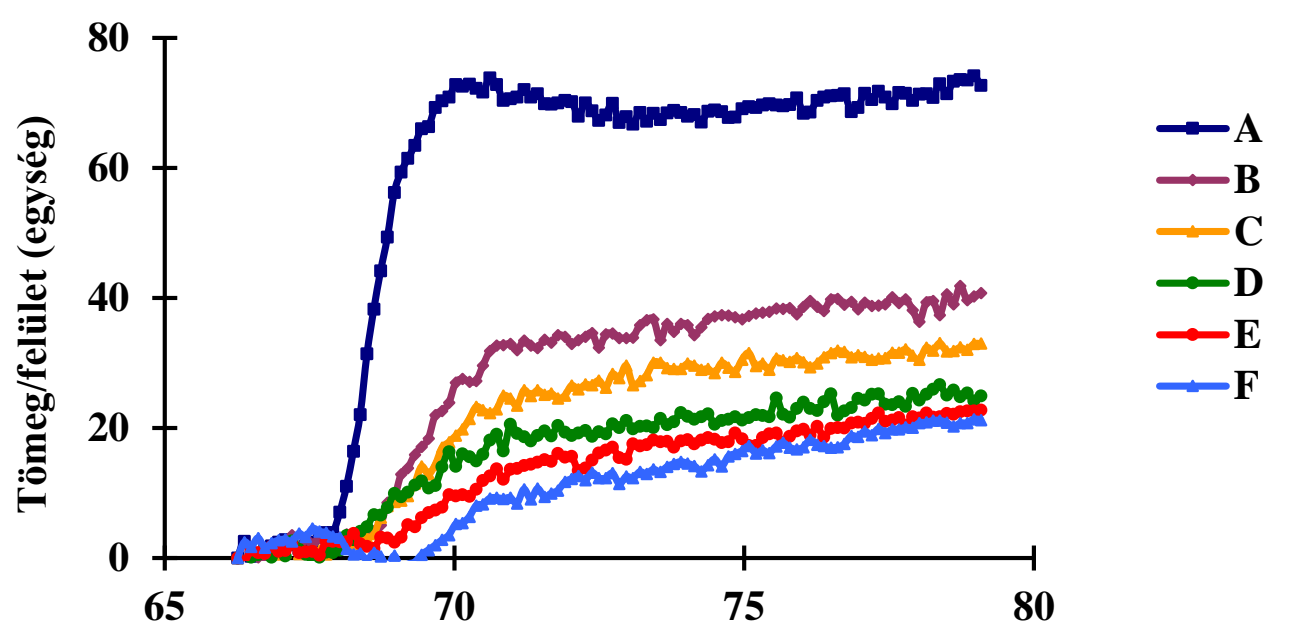

\section{Idő (perc)}

16. ábra Szenzorjelek az anti-DON szérum hígításának függvényében

(512 ng/ml DON-BSA; $120 \mu \mathrm{l} /$ perc; $24,5^{\circ} \mathrm{C}$; anti-DON koncentráció: A: 63,6 $\mu \mathrm{g} / \mathrm{ml}, \mathrm{B}: 15,9$ $\mu \mathrm{g} / \mathrm{ml}, \mathrm{C}: 8,0 \mu \mathrm{g} / \mathrm{ml}, \mathrm{D}: 6,4 \mu \mathrm{g} / \mathrm{ml}, \mathrm{E}: 3,2 \mu \mathrm{g} / \mathrm{ml}, \mathrm{F}: 2,5 \mu \mathrm{g} / \mathrm{ml})$ 


\subsection{A rögzített antigén optimális koncentrációjának meghatározása}

A szenzor válaszjeleit és érzékenységét nem csak a szérum koncentrációja, de a felületre kovalensen kötött antigén mennyisége is befolyásolja. Annak érdekében, hogy meghatározzam a szenzort borító antigén mennyiségének hatását, az aminoszilanizált szenzor felületére különböző mennyiségben rögzítettem a DON-BSA konjugátumot (128, 256, $512 \mathrm{ng} / \mathrm{ml})$. A vizsgálatban 120 $\mu 1 /$ perc áramlási sebességet alkalmaztam, míg a szenzortartó küvetta hőmérsékletét $24,5{ }^{\circ} \mathrm{C}$-on termosztáltam. A $16 \mu \mathrm{g} / \mathrm{ml}$ koncentrációjú poliklonális szérumot 1:1 arányban kevertem össze a különböző koncentrációjú DON standardokkal (0,1 ng/ml, $1 \mathrm{ng} / \mathrm{ml}, 10 \mathrm{ng} / \mathrm{ml})$ és 3 perc inkubálás után injektáltam a rendszerbe. A szenzor felületén $128 \mathrm{ng} / \mathrm{ml}$ DON-BSA konjugátum rögzítésével a standardokra $21,7 \pm 1,2 ; 16,7 \pm 1,2$ és 10,1 $\pm 0,7$ egység jelet mértem. A 256 ng/ml koncentrációjú konjugátum rögzítése esetén, a jelek ugyan csak enyhén nőttek, de a stabilitásuk javult, szórásuk csökkent $(23,3 \pm 0,7 ; 18,0 \pm 0,5,12,7 \pm 0,5$ egység). Ugyanakkor $512 \mathrm{ng} / \mathrm{ml}$ koncentrációjú konjugátumot rögzítve a jelek ugyan nagyobbak lettek (29,4 $\pm 0,3 ; 25,8 \pm 0,2$ és 24,5 $\pm 0,2$ egység), azonban a jelek közötti különbségek szignifikánsan csökkentek. A 17. ábra a vakoldathoz (csak antitestet tartalmazó oldat) képest mért jelcsökkenést mutatja be a különböző koncentrációban rögzített DON-BSA konjugátum esetében.

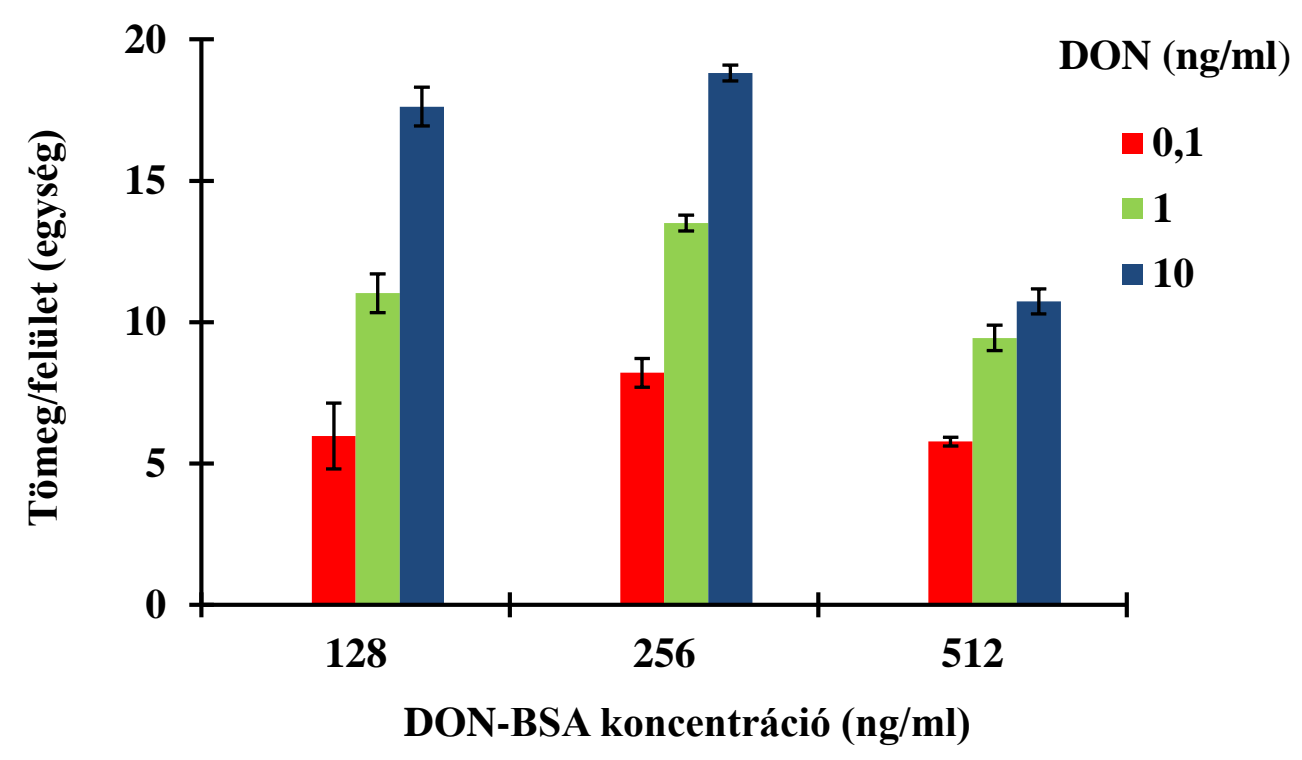

17. ábra DON válaszjelének csökkenése a vakoldathoz képest különböző koncentrációjú DONBSA konjugátum rögzítése esetén

Az eredmények alapján a további mérésekhez 256 ng/ml koncentációjú DON-BSA-konjugátumot rögzítettem a szenzor felületén. 


\subsubsection{3 Áramlási sebesség hatásának vizsgálata}

Vizsgáltam a FIA rendszerben az áramlási sebesség hatását a mérési görbék nagyságára. A rendszerben folyamatosan áramló puffer (TRIS pH 7,4) sebességét egy Gilson Miniplus 3 típusú perisztaltikus pumpával szabályoztam. Az optimális áramlási sebesség meghatározásához a vizsgált áramlási sebességek $0,04 \mathrm{ml} /$ perc, $0,08 \mathrm{ml} /$ perc, $0,12 \mathrm{ml} /$ perc voltak. A vizsgálatban a szenzor felületére $256 \mathrm{ng} / \mathrm{ml}$ DON-BSA konjugátumot rögzítettem glutáraldehiddel. Az antitestet $8 \mu \mathrm{g} / \mathrm{ml}$ koncentrációban alkalmaztam. A mérést $20^{\circ} \mathrm{C}$-on termosztálva 1 perc inkubációs idő elteltével végeztem. Mintaként 0 ; 1,0 és $10 \mathrm{ng} / \mathrm{ml}$ tartalmú DON standardot injektáltam, és vizsgáltam a standardok által adott válaszjelek nagyságát. Eredményeim alapján megállapítottam, hogy a $0,12 \mathrm{ml} /$ perc áramlási sebességnél kapok a legnagyobb és leghatározottabb jeleket (az 1


sebességet a rendszerben, feltehetően a lamináris áramlás hatására a puffer egy álló réteget képez a chip felületén, így a mintában szabadon maradt antitestek nem tudnak megfelelöen a chip felületén rögzített antigénhez kötődni, ami megmagyarázza a standardok által adott válaszjelek csökkenését. A $0,08 \mathrm{ml} /$ perc és $0,04 \mathrm{ml} /$ perc áramlási sebességnél az $1 \mathrm{ng} / \mathrm{ml}$ DON tartalmú standard válaszjele $22,87 \pm 0,18$ és $22,0 \pm 0,42$ egység volt. Nagyobb áramlási sebességnél pedig a rövidebb tartózkodási idő miatt kevesebb komplex alakulhat ki. A továbbiakban a méréseknél 0,12 $\mathrm{ml} /$ perc áramlási sebességet alkalmaztam.

\subsection{Inkubációs hömérséklet hatásának vizsgálata}

A vizsgálat során $256 \mathrm{ng} / \mathrm{ml}$ DON-BSA konjugátumot rögzítettem glutáraldehiddel a szenzor felületén, az antitestet $8 \mu \mathrm{g} / \mathrm{ml}$ koncentrációban alkalmaztam, a mérést 1 perc inkubációs idő elteltével végeztem $0,12 \mathrm{ml} /$ perc áramlási sebesség mellett. Mintaként 0,1 és $10 \mathrm{ng} / \mathrm{ml}$ tartalmú

DON standardot injektáltam. Mérés során mind a mintát, mind a szenzort ugyanazon a hőmérsékleten termosztáltam. Vizsgáltam a 20,22, 25, 28, 33, $38^{\circ} \mathrm{C}$-on történő inkubálás hatását (18. ábra). Az ábrán a $0 \mathrm{ng} / \mathrm{ml}$ DON standardot tartalmazó minta különböző hőmérsékleten történő inkubálását követően felvett válaszjelei láthatók. Megállapítottam, hogy a hőmérséklet emelésével az egyes standardok által adott válaszjelek nagysága csökken. Legnagyobb jeleket $20{ }^{\circ} \mathrm{C}$-on történő inkubálással értem el. 




18. ábra Inkubációs hőmérséklet válaszjelre gyakorolt hatása. (512 ng/ml DON-BSA; 0,12 $\mathrm{ml} /$ perc; A: $20^{\circ} \mathrm{C}, \mathrm{B}: 2{ }^{\circ} \mathrm{C}, \mathrm{C}: 25^{\circ} \mathrm{C}, \mathrm{D}: 28^{\circ} \mathrm{C}, \mathrm{E}: 38^{\circ} \mathrm{C}$ )

\subsection{Inkubációs idö hatásának vizsgálata}

A vizsgálathoz $256 \mathrm{ng} / \mathrm{ml}$ DON-BSA konjugátumot rögzítettem glutáraldehiddel a szenzor felületén, az antitestet $8 \mu \mathrm{g} / \mathrm{ml}$ koncentrációban alkalmaztam. A méréseket a minta $20{ }^{\circ} \mathrm{C}$-on történő termosztálásával és $0,12 \mathrm{ml} /$ perc áramlási sebesség alkalmazása mellett végeztem. Mintaként $0,1,10 \mathrm{ng} / \mathrm{ml}$ DON tartalmú standardot alkalmaztam. Vizsgáltam a $0,1,3$ percig történő inkubálás mérésre gyakorolt hatását. Vizsgálataimból megállapítottam, hogy inkubálás nélkül a standardokra kapott jelek igen nagyok $(22,33 \pm 0,82 ; 19,88 \pm 0,63 ; 21,66 \pm 1,20$ egység), azonban a koncentrációval nem arányosak. Ez azért van, mert nincs idő arra, hogy a mintában lévő antitest az antigénnel kapcsolódjon, így sok nem kötött antitest marad a mintában, ami nagy jelet ad, de nem reprezentálja a mintában lévő antigén mennyiséget. Vizsgálatomban a standardokra 3 perces inkubálásnál már a koncentrációval arányos jeleket kaptam $(16,97 \pm 0,54 ; 12,80 \pm 0,77$;

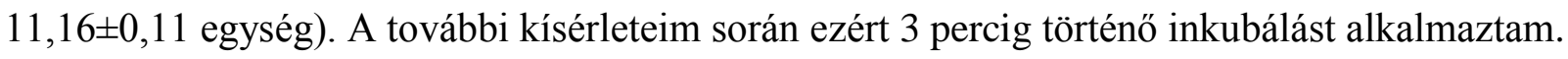

\subsection{DON meghatározására alkalmas immunszenzor statisztikai paraméterei}

A DON vizsgálatára alkalmas immunszenzor müködési paramétereinek meghatározása után kalibrációs görbét készítettem 0,001-100 ng/ml koncentráció tartományban. A szenzor felületén $256 \mathrm{ng} / \mathrm{ml}$ DON-BSA konjugátumot rögzítettem. A standard oldatokat, amelyek különböző koncentrációban tartalmazták az antigént (0,001-100 ng/ml) $8 \mu \mathrm{g} / \mathrm{ml}$ koncentrációjú antitest oldattal 1:1 arányban kevertem össze és 3 percig történő inkubálást követően injektáltam a rendszerbe. Meghatároztam a kalibrációs görbe dinamikus mérési tartományát (19. ábra). 


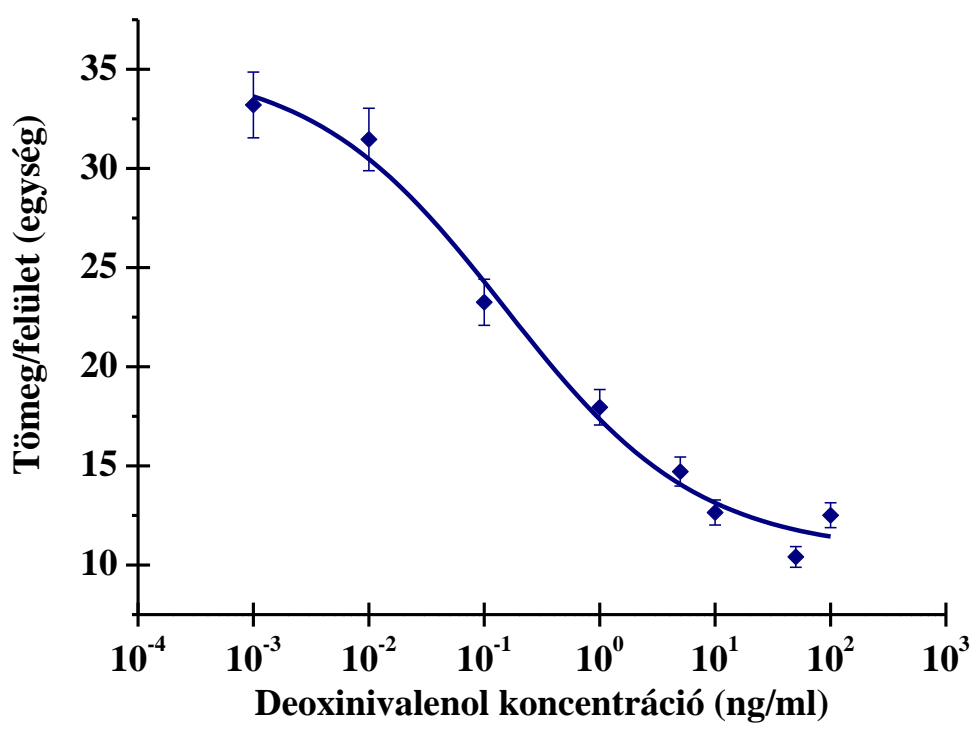

19. ábra DON indirekt mérésének kalibrációs görbéje (256 ng/ml DON-BSA, 8,0 $\mu \mathrm{g} / \mathrm{ml}$ antitest, statisztikai paraméterek: $\chi^{2} /$ szabadsági fok $=1,57 ; \mathrm{r}^{2}=0,99 ; \mathrm{IC}_{50}$ értéke $0,15 \pm 0,08 \mathrm{ng} / \mathrm{ml}$ )

Az eredményeim alapján az indirekt mérési elven müködő jelölésmentes immunszenzor dinamikus méréstartománya 0,01-50 ng/ml DON, a LOD 0,001 ng/ml, míg a gátlási középérték (IC50) 0,15 $\pm 0,08 \mathrm{ng} / \mathrm{ml}$ volt. Ez a méréstartomány két nagyságrenddel kisebb, mint a direkt szenzor esetében, és közel egy nagyságrenddel kisebb, mint ami a hasonló immunszenzorokkal elérhető SPR detektálással (Mak et al., 2010; Actis et al., 2010).

\subsection{Valós minták mátrixhatása}

GC-MS technikával igazoltan DON-mentes búzalisztet mesterségesen szennyeztem különböző koncentrációban $(0,005 ; 0,001 ; 0,05 ; 0,1 ; 0,5 ; 1,0 ; 5,0 ; 10$ és $50 \mathrm{mg} / \mathrm{kg})$ DON-nal a 4.3.1. fejezetben leírtak szerint. A szürleteket $42 \mathrm{mM-os} \mathrm{pH} \mathrm{7,4-es} \mathrm{TRIS} \mathrm{pufferrel} \mathrm{hígítottam} \mathrm{és}$ 1000-szeres 10000-szeres és 100000-szeres végső hígításban vizsgáltam a minták által adott válaszjeleket. A FIA rendszerben áramló pufferként acetonitril:víz 6:4 arányú keverékét tartalmazó TRIS-t használtam, ahol a puffer az oldószert ugyan olyan koncentrációban tartalmazta, mint a hígított minta. Megállapítottam, hogy 1000-szeres hígítást alkalmazva a nagy mátrixhatás miatt kicsi volt az egyes minták közötti jelek különbsége. A 100000-szeresen hígított mintáknál bár alig van mátrixhatás, a jelek kicsik, a vizsgált méréstartományban már nem volt megfelelően érzékeny a szenzor. A 10000-szeres hígításnál a mátrixhatás nem zavarta a mérést, ugyanakkor a jelek megfelelően stabilak és reprodukálhatóak voltak. A továbbiakban tehát a valós mintákat 10000-szeres hígításban vizsgáltam. A DON-nal szennyezett mintákkal nyert kalibrációs görbét a 20. ábra mutatja be. 


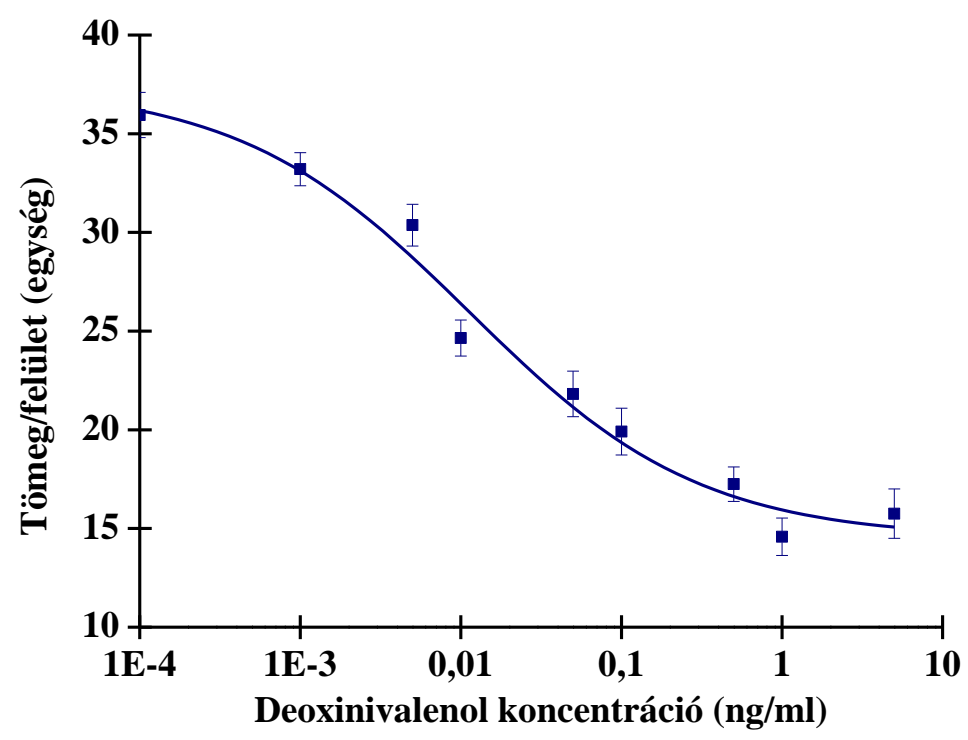

20. ábra DON-nal mesterségesen szennyezett búzaminták kalibrációs görbéje ( $256 \mathrm{ng} / \mathrm{ml}$ DON-

BSA; $8,0 \mu \mathrm{g} / \mathrm{ml}$ antitest, statisztikai paraméterek: $\chi^{2} /$ szabadság fok $\left.=1,90 ; \mathrm{r}^{2}=0,98\right)$

A lineáris méréstartomány a liszt mintára számolva $0,005-50 \mathrm{mg} / \mathrm{kg}$ volt, míg az $\mathrm{IC}_{50}$ értéke $0,13 \pm 0,04 \mathrm{mg} / \mathrm{kg}$ értékünek adódott, ami megfelel a követelményeknek (200 $\mu \mathrm{g} / \mathrm{kg}$ csecsemöknek és kisgyermekeknek szánt gabona alapú feldolgozott élelmiszerek esetén, $1750 \mu \mathrm{g} / \mathrm{kg}$ feldolgozatlan durumliszt, kukorica, zab esetén és $1250 \mu \mathrm{g} / \mathrm{kg}$ más feldolgozatlan gabona esetén, $700 \mu \mathrm{g} / \mathrm{kg}$ tésztáknál, $500 \mu \mathrm{g} / \mathrm{kg}$ kenyér és cereália alapú élelmiszerek esetén (Commission Regulation (EC) No 1881/2006).

\subsection{Biológiai minták vizsgálata}

Biológiai minták vizsgálatát a kialakított kompetitív szenzorral végeztem. „Ismeretlen” mintaként GC-MS technikával igazoltan DON-mentes búzalisztet szennyeztem különbözö koncentrációban DON-nal a 4.3.1. fejezetben leírtak szerint. A mintákat 10000-szeres hígításban vizsgáltam. A minták méréséhez a kalibrációt az 5.2.2.3.7. fejezetben leírtak szerint vettem fel, majd vizsgáltam az ,ismeretlen minták” válaszjeleit és meghatároztam a visszanyerés \%-át. A 3. táblázatban az „ismeretlen” minták mérési és visszanyerési eredményeit foglaltam össze. 
3. táblázat: DON visszanyerés eredményei búzaliszt mintákból

\begin{tabular}{|c|c|c|}
\hline $\begin{array}{c}\text { Hozzáadott DON } \\
(\mathrm{mg} / \mathrm{kg})\end{array}$ & $\begin{array}{c}\text { Mért DON } \\
(\mathrm{mg} / \mathrm{kg})\end{array}$ & $\begin{array}{c}\text { Visszanyerés } \\
(\%)\end{array}$ \\
\hline 0,005 & $0,006 \pm 0,002$ & 123,0 \\
\hline 0,01 & $0,011 \pm 0,004$ & 114,0 \\
\hline 0,05 & $0,05 \pm 0,01$ & 92,0 \\
\hline 0,1 & $0,11 \pm 0,02$ & 108,2 \\
\hline 0,5 & $0,47 \pm 0,05$ & 94,5 \\
\hline 1,0 & $1,1 \pm 0,1$ & 109,3 \\
\hline 5,0 & $04,7 \pm 1,3$ & 93,1 \\
\hline 10,0 & $11,0 \pm 1,0$ & 111,0 \\
\hline 50,0 & $46,0 \pm 4,3$ & 91,6 \\
\hline
\end{tabular}

Az eredmények alapján megállapítottam, hogy a búzalisztből a DON mikotoxint a mintaelőkészítés során 91,6-123,0\%-ban nyertem vissza, a minta-előkészítés és az immunszenzorral végzett meghatározás megfelelt a követelményeknek.

\subsection{Immunszenzor fejlesztés vitellogenin meghatározásra}

\subsubsection{A szenzorfejlesztéshez szülkséges immunanyagok előállítása}

Irodalmi adatok alapján (Hara et al., 2007; Vincent 2001; Volz and Chandler 2004; Holbech et al., 2001) a vitellogenin (Vtg) és lipovitelin (Lpv) fehérje ugyanazon fajban 95\%-os keresztreakciót mutat egymással. Mivel a Lpv izolálása lényegesen egyszerübb, ezért ezt alkalmaztam immunogénként / antigénként a Vtg immunszenzorok fejlesztéséhez. A lipovitellinek tisztítása nőstény ponty illetve vöröshasú unkából a 4.2.6. fejezetben ismertett módszer szerint történt. A tisztított Lpv fehérjével magyar vadas óriásnyúlban történő immunizálással poliklonális antitestet állítottam elő.

\subsubsection{Lipovitellin fehérjefrakciók ellenörzése SDS-PAGE vizsgálattal}

A Lpv-preparátumok tisztaságát nátrium-dodecil-szulfát poliakrilamidgélelektroforézissel (SDS-PAGE) vizsgáltam (21. ábra) a 4.2.8. fejezetben leírt módszer szerint. A gélképek alapján a ponty-Lpv vizsgálatakor 110000-120000, 96000 és 85000 Da fehérjefrakciókat különböztettem meg, míg a béka-Lpv-preparátum esetében 170000 és 98000 Da frakciókat kaptam. A ponty-Lpv fehérjefrakcióira kapott eredmények megegyeznek a Hara és mtsai (2007) által publikált adatokkal (113000 és 96000 Da). 


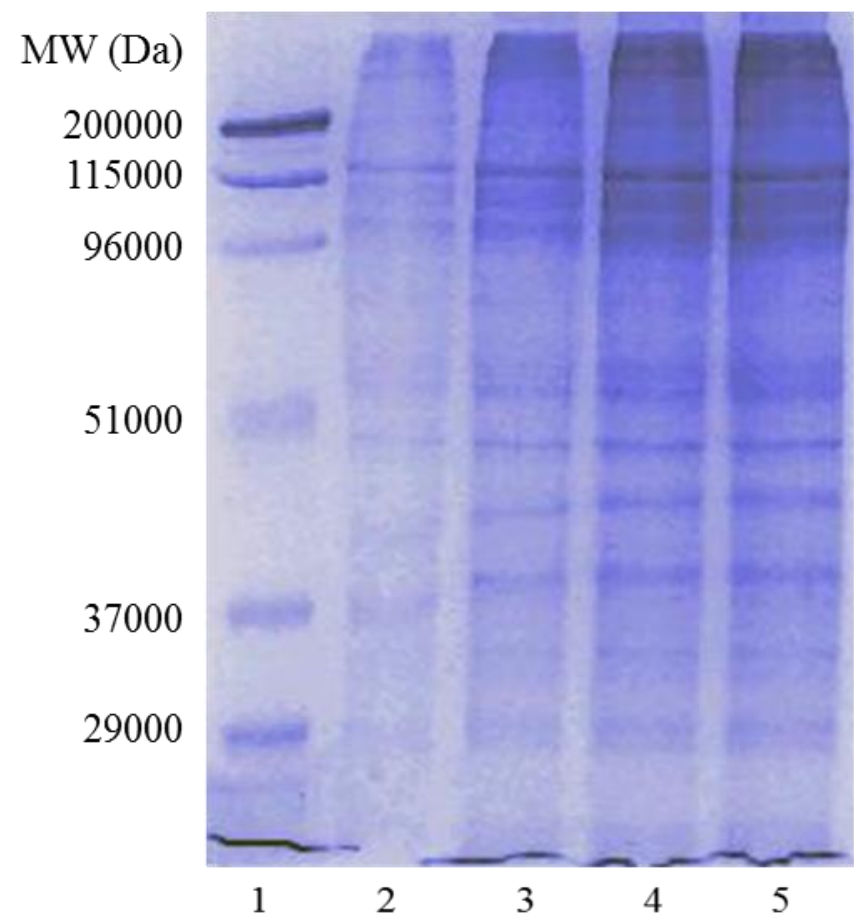

21. ábra: Ponty eredetű Lpv fehérjefrakciók vizsgálata SDS-PAGE módszerrel (1: molekula standard, 2: 2,5 $\mu 1$ lipovitellin, 3: $5 \mu 1$ lipovitellin, 4: $8 \mu 1$ lipovitellin, 5: $10 \mu 1$ lipovitellin)

Összehasonlítottam a ponyt illetve béka Lpv futtatási mintázatát SDS-PAGE módszerrel, melyet a 22. ábra szemléltet.

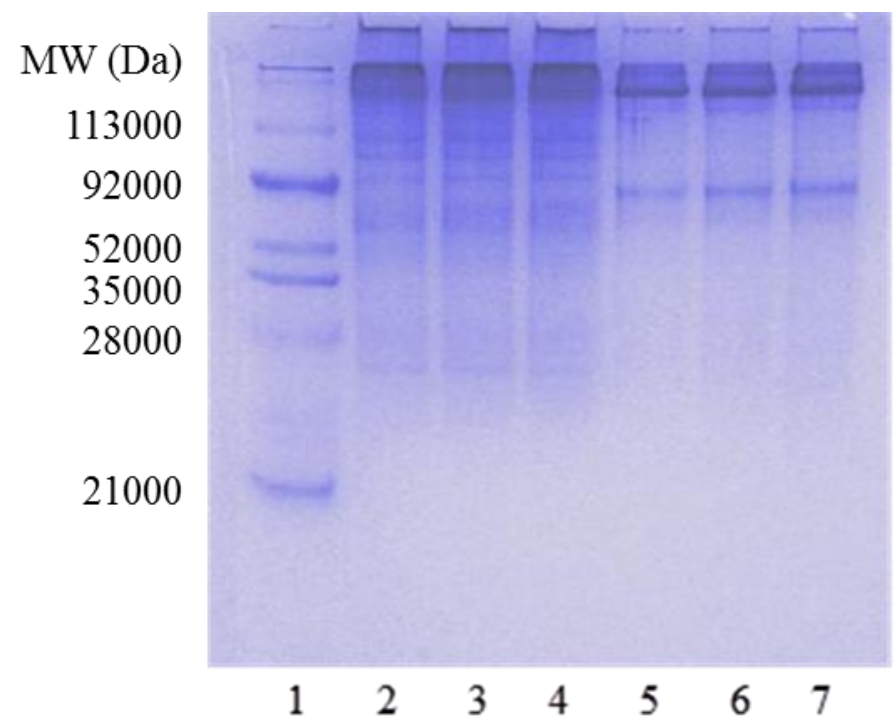

22. ábra Ponty és béka lipovitellin összehasonlítása SDS PAGE-val (1: molekula standard, 2: 8 $\mu 1$ ponty lipovitellin, 3: $10 \mu 1$ ponty lipovitellin, 4: $12 \mu 1$ ponty lipovitellin, 5: $8 \mu 1$ béka lipovitellin, 6: $10 \mu 1$ béka lipovitellin, 7: $12 \mu 1$ béka lipovitellin) 
A gélek alapján megállapítható, hogy a pontyból és a békából tisztított lipovitellin különbözik egymástól, a lipovitellin fajspecifikus fehérje. A béka és ponty lipovitellin preparátumok alkalmasak az immunizálás elvégzésére.

\subsubsection{Ponty és béka lipovitellin specifikus poliklonális antitest elöállitása}

Ponty és béka Lpv ellen specifikus poliklonális antitesteket termeltettem magyar vadas óriásnyúlban történő immunizálással Harboe és Inglid (1973) módszerét követve. Mindkét esetben az immunizáláshoz a tisztított Lpv frakciókat alkalmaztam. A homogenizált Lpvpreparátumoldatokból $1 \mathrm{ml}$ térfogatnyit centrifugáltam, majd a fehérjét $0,2 \mathrm{~mol} / \mathrm{l} \mathrm{NaCl}$-oldatban visszaoldottam, úgy hogy $1 \mathrm{mg} / \mathrm{ml}$ oldatot kapjak. Ezekkel az antigénoldatokkal immunizáltam nyulakat a 5.2.1.3. fejezetben ismertetett eljárással, majd IgG-re tisztítottam a szérumokat (lsd.

\subsubsection{4. fejezet).}

\subsubsection{Ponty lipovitellin specifikus antitest antigénnel szembeni aktivitásának vizsgálata}

A nyulak immunizálásával nyert ponyt Lpv specifikus antitestet tartalmazó szérumot ELISA rendszerrel vizsgáltam az 5.2.1.5. fejezetben leírtak alapján. Az eredmények alapján (23. ábra) megállapítottam, hogy a két nyúlból származó szérum aktivitása ugyan eltér egymástól, de mindkét nyúlból származó szérum és tisztított IgG is alkalmas a szenzorfejlesztésre. A legnagyobb aktivitást a B szérum és az abból előállított tisztított szérum mutatta, ezért a továbbiakban ezt használtam a szenzor kialakításához. A kiválasztott szérum összes fehérjetartalma $43 \mathrm{mg} / \mathrm{ml}$ értékűnek adódott.

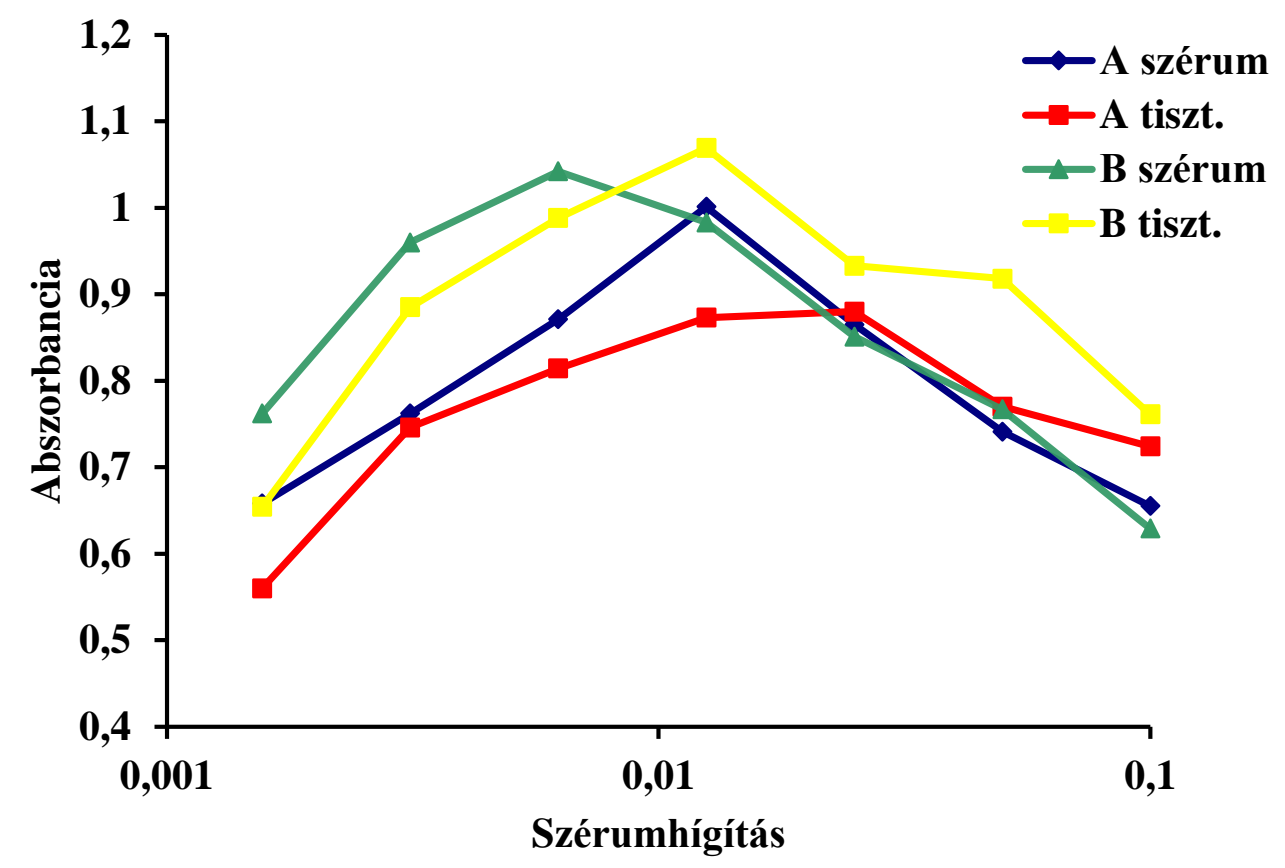

23. ábra Ponty lipovitellin specifikus szérum és a tisztított IgG frakciók ellenőrzése direkt ELISA módszerrel 


\subsubsection{Béka lipovitellin specifikus antitest antigénnel szembeni aktivitásának vizsgálata}

A szérumok jellemzésére a nyers szérum mintát és a tisztított szérumot használtam fel. Az eredmények alapján (24. ábra) megállapítottam, hogy a B nyúlból származó szérum illetve abból előállított tisztított IgG aktivitása a nagyobb, azonban az A nyúlból származó szérum is alkalmas a vitellogenin meghatározására. A tisztított B szérum összes fehérjetartalma 17,6 mg/ml volt.

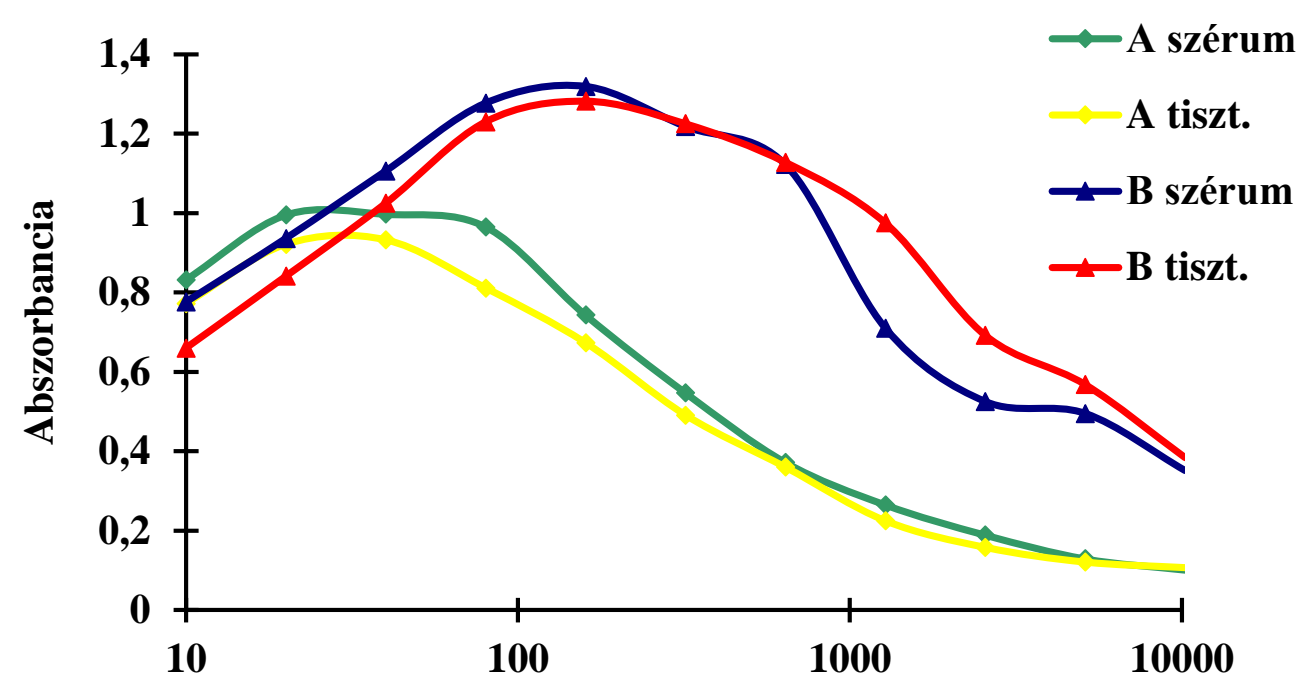

Szérumhígítás

24. ábra: Béka lipovitellin specifikus szérum és a tisztított IgG frakciók ellenőrzése direkt ELISA módszerrel

\subsubsection{Immunszenzor fejlesztése ponyt vitellogenin kimutatásra}

\subsubsection{Direkt mérési módszer ponty vitellogenin mérésére}

A kísérletekhez aminoszilanizált hullámvezető szenzort használtam, melynek felületére a direkt szenzor esetén ponty Lpv ellen termeltetett antitest került rögzítésre kovalens kötéssel. Az érzékenyítés során a felület aminocsoportjait $200 \mu$, desztillált vízben hígított, 2,5\%-os glutáraldehid oldattal aktiváltam. Ezt követően a felületet desztillált vízzel mostam, majd az áramló közeget 42 mM-os pH 7,4-es TRIS pufferre cseréltem. Mosást követően a felületre 43 $\mu \mathrm{g} / \mathrm{ml}$ poliklonális szérumot adagoltam. A felületen meg nem kötött anyagok lemosásához, illetve az egyes minták mérése után a szenzor regenerálásához $200 \mu 10$ mM-os sósavoldatot alkalmaztam. A 25. ábrán a glutáraldehiddel történő immobilizáció egyes lépéseire adott szenzorválasz, illetve a szenzor felületére különböző koncentrációban $(1,5 ; 1,9 ; 3,0 ; 3,8 ; 6,0 ; 12$ $\mu \mathrm{g} / \mathrm{ml})$ adagolt Lpv antigén specifikus kötődéséből adódó szenzorjelek láthatók. A szenzorjel nagyságának növekedése egyenes arányban áll az alkalmazott Lpv koncentráció növekedésével. 


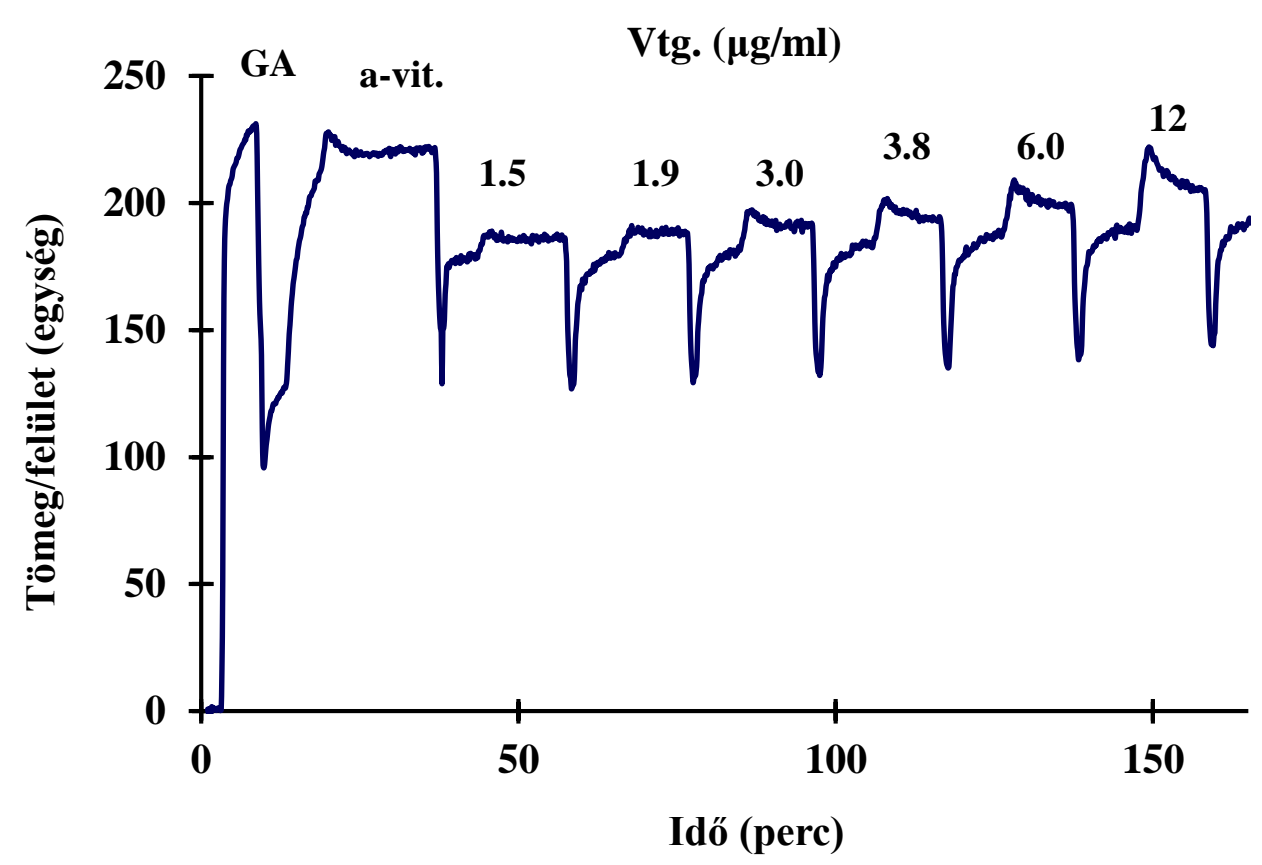

25. ábra Anti-Lpv ( $43 \mu \mathrm{g} / \mathrm{ml})$ immobilizációja és a különböző koncentrációjú Lpv standardok (1,5-12 $\mu \mathrm{g} / \mathrm{ml})$ által adott szenzorválaszok (42 mM-os pH 7,4 TRIS puffer, 0,08 $\mathrm{ml} /$ perc áramlási sebesség)

A direkt vagy nem-kompetitív immunszenzorok fejlesztésekor elsősorban a hullámvezetö felületén rögzített poliklonális vitellogenin-specifikus szérum minösége és mennyisége (hígitása) az érzékenységet meghatározó tényező. Annak érdekében, hogy megtaláljam a rögzítendő antitest megfelelő koncentrációját különböző hígításban $(215,86,43,21,5$ és 8,6 $\mu \mathrm{g} / \mathrm{ml})$ rögzítettem a szérumot az aminoszilanizált szenzor felületén és vizsgáltam a vitellogenin standardokra adott válaszjel nagyságát. Ha a szenzor felületén kis hígításban $(215 \mu \mathrm{g} / \mathrm{ml}$ és $86 \mu \mathrm{g} / \mathrm{ml})$ rögzítettem a poliklonális szérumot, nagyon sok antitest rögzült a felszínen, vastag, feltehetően nem monomolekuláris réteget kaptam, és a Lpv standardra kapott válaszjelek viszonylag kicsik voltak

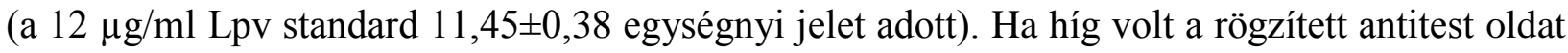
(21,5 és $8,6 \mu \mathrm{g} / \mathrm{ml}$ ), akkor ugyan érzékenyebb volt a szenzor, a korábbiakhoz képest nagyobb válaszjeleket kaptam, azonban a szenzorral csak néhány mérést lehetett elvégezni, gyorsan kimerült. A vizsgálataim során a $43 \mu \mathrm{g} / \mathrm{ml}$ (1:1000 hígított) szérum glutáraldehiddel való rögzítése esetén kaptam a legjobb eredményeket. A 26. ábrán a direkt szenzor kalibrációs görbéje látható. 


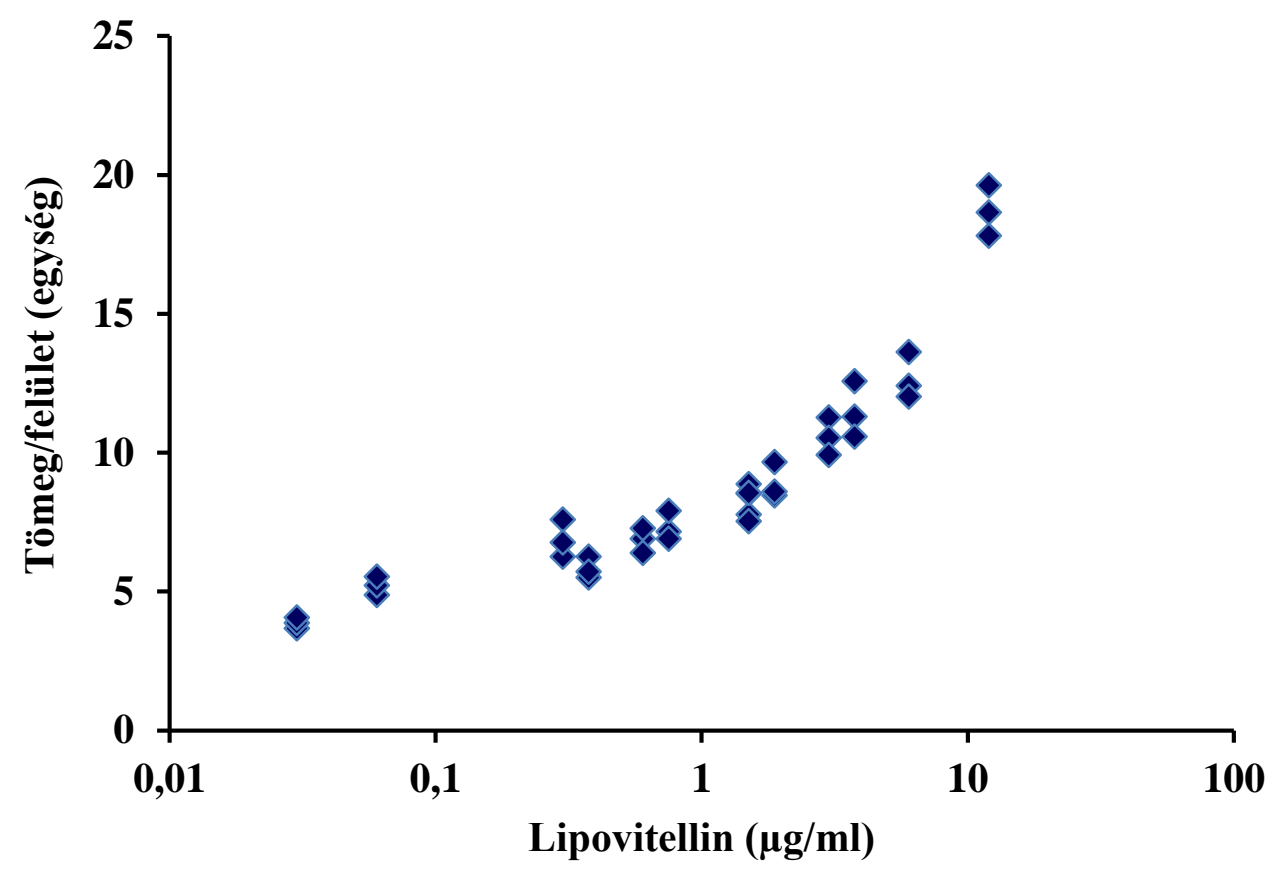

26. ábra Direkt immunszenzor kalibrációs görbéje $43 \mu \mathrm{g} / \mathrm{ml}$ szérum rögzítése esetén

A mérés dinamikus tarománya 0,6 és $12 \mu \mathrm{g} / \mathrm{ml}$ közt volt standard oldatok esetén. A standard


megfelelően. A Lpv kimutatási határa $0,3 \mu \mathrm{g} / \mathrm{ml}$ volt. Ezen adatok alapján a direkt OWLS mérési módszer nem megfelelő ponyt Vtg tartalmának meghatározására, ezért vizsgáltam a kompetitív mérési rendszer kialakításának lehetőségét az érzékenység növelésének érdekében.

\subsubsection{Kompetitív immunszenzor kifejlesztése ponty Vtg meghatározásra}

Kompetitív mérési elrendezésben az aminoszilanizát szenzor felületére kovalens kötéssel (2,5\%-os glutáraldehiddel) a tisztított Lpv megfelelő koncentrációban került rögzítésre. A standardokat, illetve a mintákat 1:1 arányban kevertem össze meghatározott koncentrációjú poliklonális szérummal, 1 percig szobahőmérsékleten inkubáltam majd injektáltam az áramló rendszerbe. A mérés során, az inkubáció alatt nem kötődött, szabadon maradt antitestek a szenzor felületére rögzített antigénhez kötődnek, így a szenzor felületére kötődött antitestek mennyisége fordítottan arányos a minta antigén tartalmával.

\subsection{Alkalmazott poliklonális antitest koncentrációjának meghatározása}

Kompetitív szenzor kialakítása esetén az alkalmazott poliklonális szérum mennyiségének meghatározása az egyik legfontosabb paraméter. A kísérletben az aminoszilanizált szenzor felületére 2,5\%-os glutáraldehiddel $5 \mu \mathrm{g} / \mathrm{ml}$ ponty Lpv-t rögzítettem, és vizsgáltam a különböző koncentrációjú $(430 ; 215 ; 86 ; 64,1 ; 43 ; 32,3 ; 21,5 \mu \mathrm{g} / \mathrm{ml}$ anti-Lpv) poliklonális szérumra adott válaszjel nagyságát. A szenzor kialakításához mindig azt az alkalmazott antitest koncentrációt kell 
választani, ami éppen telíti a szenzor felületét. Abban az esetben, ha kis antitest koncentrációt (21,5 és 43,0 $\mu \mathrm{g} / \mathrm{ml}$ anti-Lpv) alkalmaztam, a szenzor érzékenysége megnőtt, ugyanakkor kicsi,

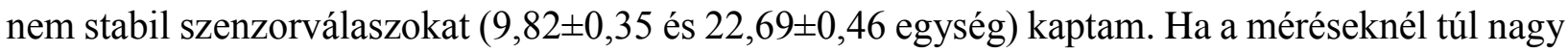
koncentrációban használtam az antitestet (215 és $430 \mu \mathrm{g} / \mathrm{ml}$ anti-Lpv) akkor a szenzorválasz nagysága megnőtt $(44,89 \pm 1,39$ és 46,96 $\pm 0,44$ egység), de az érzékenység jelentősen lecsökkent, mivel sok antitest molekula maradt szabadon kis koncentrációjú standardok esetében. A mérési görbéket a 27. ábra mutatja be. Megfelelő eredményeket 64,1 és $86 \mu \mathrm{g} / \mathrm{ml}$ szérum alkalmazásával értem el, ahol szenzorjelként $28,83 \pm 0,76$ és $27,34 \pm 0,83$ egységet kaptam. A további vizsgálatokhoz a 64,1 $\mu \mathrm{g} / \mathrm{ml}$ koncentrációjú szérumot alkalmaztam ponyt Lpv meghatározásához.

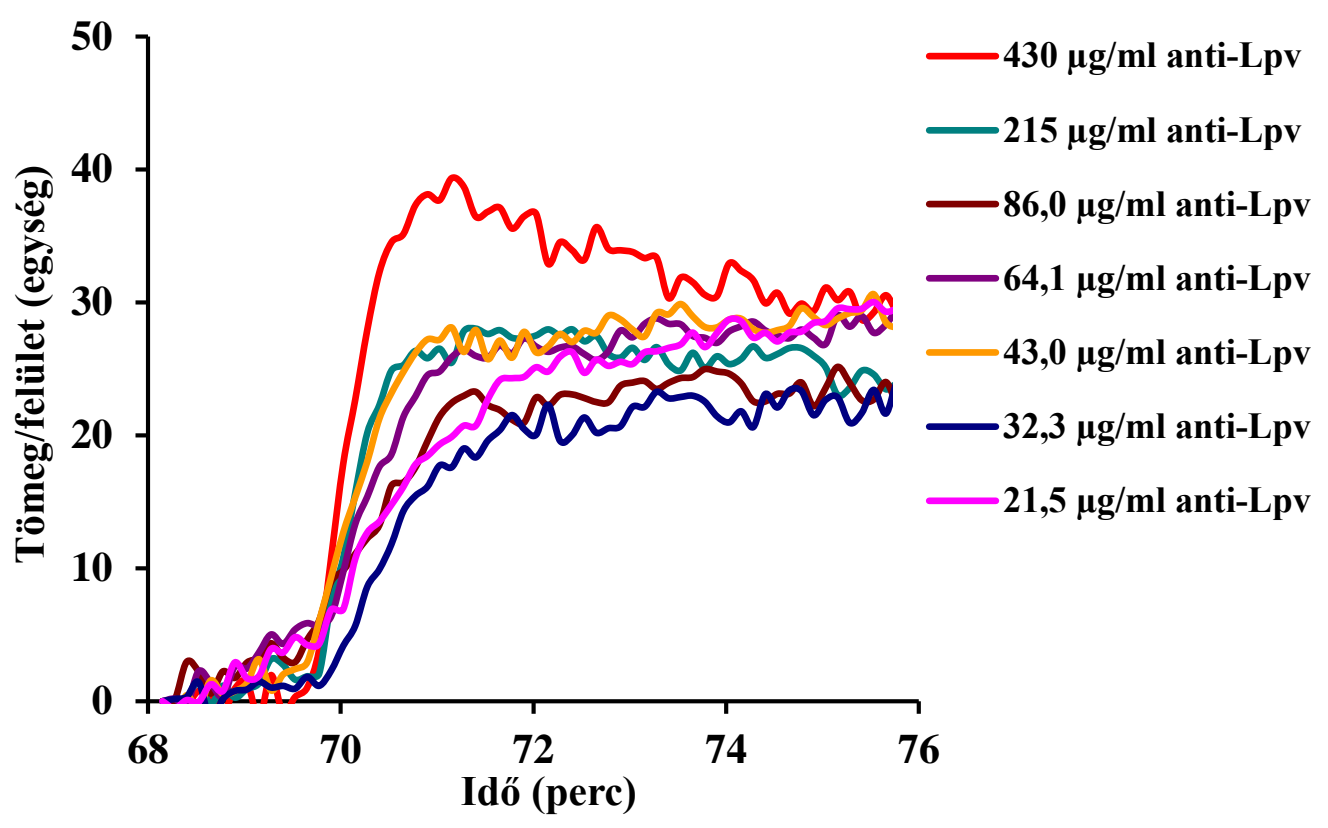

27. ábra Optimális antitestkoncentráció meghatározása kompetitív OWLS méréshez (immobilizált Lpv koncentráció $5 \mu \mathrm{g} / \mathrm{ml}$ )

\subsection{A rögzített antigén koncentráció meghatározása}

A vizsgálatban a ponty Lpv antigént különböző mennyiségben $(1 \mu \mathrm{g} / \mathrm{ml}, 3 \mu \mathrm{g} / \mathrm{ml}, 5$ $\mu \mathrm{g} / \mathrm{ml}, 10 \mu \mathrm{g} / \mathrm{ml}, 15 \mu \mathrm{g} / \mathrm{ml})$ rögzítettem a szenzor felszínére, és vizsgáltam a szérum hígított oldatára $(64,1 \mu \mathrm{g} / \mathrm{ml})$ adott válaszjel nagyságát. Abban az esetben, ha kis mennyiségben


nem stabil válaszjeleket kaptam, hisz csak nagyon kevés antitest molekula tud kötődni. Ugyanakkor, ha túl sok fehérjét rögzítettem $(10 \mu \mathrm{g} / \mathrm{ml}, 15 \mu \mathrm{g} / \mathrm{ml})$, nem kaptam arányosan nagyobb jeleket $(18,57 \pm 0,63$ és $17,85 \pm 0,81$ egység) feltehetően a sztérikus gátlás miatt. A legjobb eredményeket 3 és $5 \mu \mathrm{g} / \mathrm{ml}$ Lpv rögzítésével értem el. Ekkor a válaszjelek nagysága 
28,83 $\pm 0,76$ egység, illetve $29,67 \pm 0,79$ egység volt. Kísérleteim további részében $5 \mu \mathrm{g} / \mathrm{ml}$ koncentrációjú Lpv oldattal érzékenyítettem a szenzor felületét.

\subsection{Az áramlási sebesség hatása}

Vizsgáltam a FIA rendszerben az áramlási sebesség hatását a mérési görbék nagyságára. A rendszerben folyamatosan áramló puffer (TRIS pH 7,4) sebességét egy Gilson Miniplus 3 típusú perisztaltikus pumpával szabályoztam. A vizsgálat során a szenzor felületére $5 \mu \mathrm{g} / \mathrm{ml} \mathrm{Lpv}$ oldatot rögzítettem glutáraldehiddel. Az antitestet $64,1 \mu \mathrm{g} / \mathrm{ml}$ koncentrációban alkalmaztam és vizsgáltam a standardok által adott válaszjelek nagyságát. Az optimális áramlási sebesség meghatározásához a vizsgált áramlási sebességek 0,04 $\mathrm{ml} /$ perc, $0,08 \mathrm{ml} /$ perc, $0,12 \mathrm{ml} /$ perc, $0,16 \mathrm{ml} /$ perc, $0,20 \mathrm{ml} /$ perc valamint $0,24 \mathrm{ml} /$ perc voltak. Kísérleteim alapján megállapítottam, hogy kis áramlási sebesség mellett, a lassabb áramlás következtében, ugyan nő a minta tartózkodási ideje a mérőcellában, azonban a görbék elnyúltak, lassan áll be az egyensúlyi állapot az áramlási viszonyok miatt. Ha túl gyors az áramlás, akkor a tartózkodási idő kicsi, nincs megfelelő lehetőség a kötések kialakítására, nagyon kevés molekula kötődhet, ami kicsi jeleket eredményez. A továbbiakban a mérésekhez 0,08 ml/perc áramlási sebességet alkalmaztam.

\subsection{Az inkubáció hatása a mérésre}

A kompetitív mérések során a megfelelően hígított szérum oldatot összekevertem a standard vagy a minta oldattal, megfelelő ideig inkubáltam és a cellába injektálva mértem a szabadon marad antitestek mennyiségét. A vizsgálathoz a szenzor felületét $5 \mu \mathrm{g} / \mathrm{ml}$ ponty Lpv-el érzékenyítettem. Az áramlási sebesség 0,08 ml/ perc volt. Az antitestet 64,1 $\mu \mathrm{g} / \mathrm{ml}$ koncentrációban alkalmaztam, míg a Lpv standardokat 0,1-200 ng/ml koncentráció tartományban vizsgáltam. A szérumot és standardot összekeverve, majd különböző ideig inkubálva (0-5 perc) vizsgáltam az inkubálási idő hatását a jelekre. Megállapítottam, hogy az inkubációs idő növelésével egészen a 3 percig a szenzorválaszok szignifikánsan növekedtek, három perc felett a hosszabb inkubálási idő már nem befolyásolta a jelek nagyságát.

Vizsgáltam az inkubáció hőmérsékletének hatását is a jelekre. A kísérletet 20, 24, 30, 35 és $38{ }^{\circ} \mathrm{C}$-on végeztem. Az inkubálás körülményeit vizsgálva megállapítottam, hogy a hőmérséklet növelése nem segíti elő az immunkomplex képződését, inkább gátolja azt. A szobahőmérsékleten végzett mérés során nagyobb a mért jelek közötti különbség a 3-300 ng/ml Lpv méréstartományban, mint $38^{\circ} \mathrm{C}$-on termosztálva. A 28. ábrán a két szélsőértéken történő mérést mutatom be, a különbség kiemelése érdekében. 


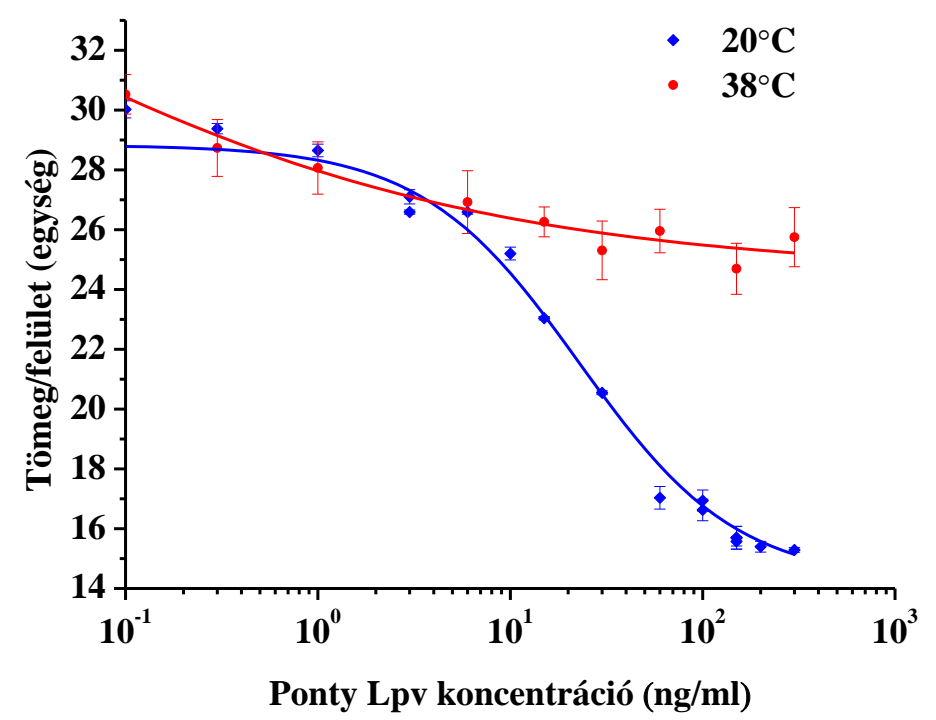

28. ábra Indirekt OWLS szenzorral készített kalibrációs görbék különböző hőmérsékleten

A 30, 60 és $150 \mathrm{ng} / \mathrm{ml}$ Lpv-standardokat $20{ }^{\circ} \mathrm{C}$-on inkubálva, a referencia antitest jeléhez képest $7,33 \pm 0,06,10,84 \pm 0,03$ és $12,18 \pm 0,04$ egység csökkenést mértem, míg ezeket a mintákat $38^{\circ} \mathrm{C}$-on inkubálva a jelcsökkenésre $5,22 \pm 0,76,4,57 \pm 0,48$ valamint $5,84 \pm 0,85$ egységet kaptam. A továbbiakban $20^{\circ} \mathrm{C}$-on végeztem a minták inkubálását.

\subsection{Dinamikus méréstartomány meghatározása}

Az optimális mérési paraméterek alkalmazásával kalibrációs görbét készítettem ponty-Lpv fehérjére 0,3-300 ng/ml méréstartományban. A 29. ábra az így felvett kalibrációs görbét mutatja be.

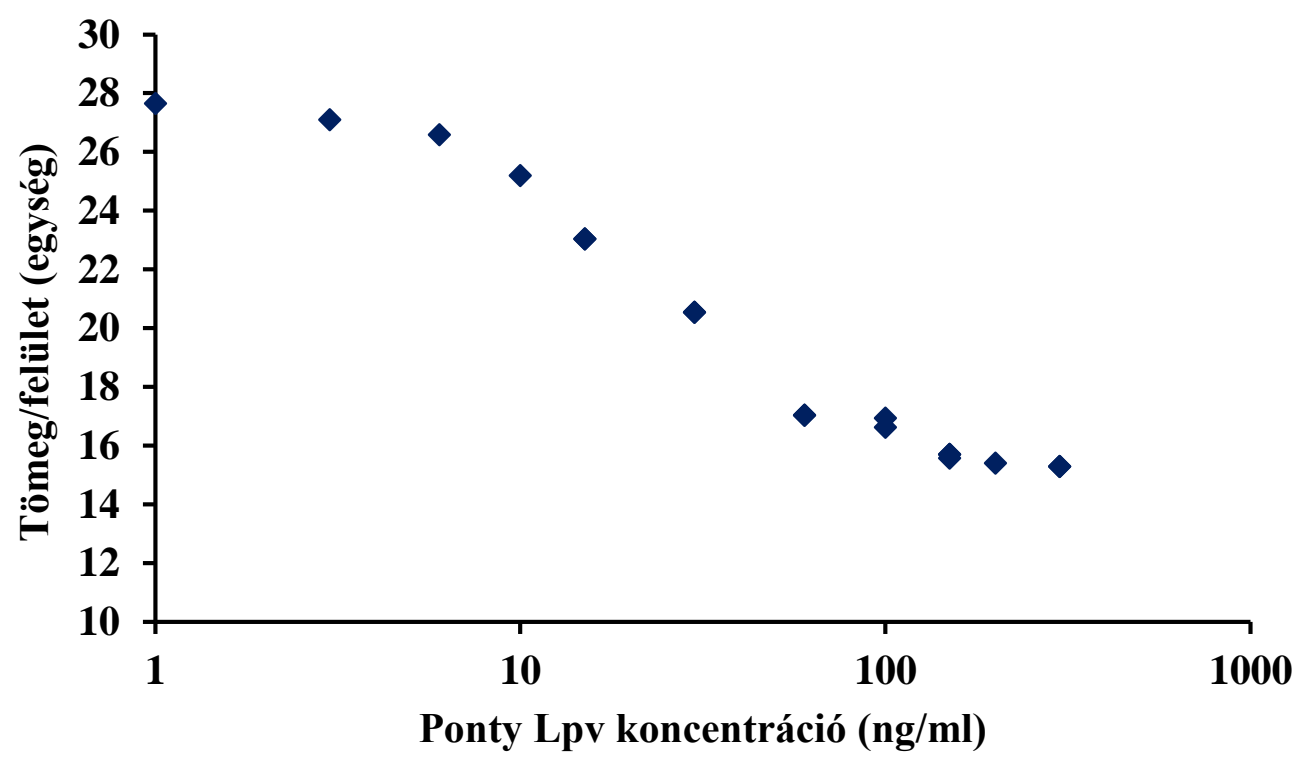

29. ábra Ponty Lpv kalibrációs görbéje indirekt OWLS szenzorral 
Kompetitív mérési módszert alkalmazva a dinamikus méréstartomány 3 és $150 \mathrm{ng} / \mathrm{ml} \mathrm{Lpv}$

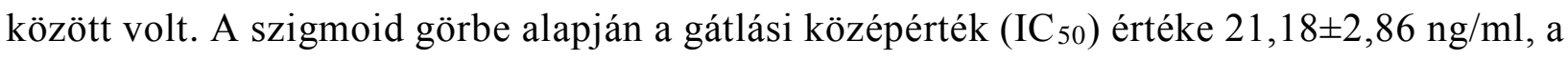
görbe meredeksége $0,99 \pm 0,12$ értékünek adódott, a kimutatás alsó határa pedig $0,7 \mathrm{ng} / \mathrm{ml}$ volt. A versengő mérés érzékenysége 2 nagyságrenddel kisebb volt, mint a direkt módszerrel mérve.

\subsection{Ponty lipovitellin antitest szubsztrát-specifitása}

Vizsgáltam a ponty lipovitellin ellen termeltetett antitestek szubsztrát-specifitását. A szenzor felületén ponty Lpv-t rögzítettem, az antitestet 64,1 $\mu \mathrm{g} / \mathrm{ml}$ koncentrációban alkalmaztam. A ponty-Lpv fehérjével érzékenyített immunszenzorral összehasonlítottam, hogy 0,$1 ; 1,0 ; 10$ és $100 \mathrm{ng} / \mathrm{ml}$ ponty- illetve béka-Lpv fehérjét tartalmazó oldatok mekkora jelcsökkenést okoznak. Ponty Lpv esetén a szenzor jel fordítottan arányos volt az antigénkoncentrációval, míg béka Lpv esetén a szenzorválasz közel azonos maradt egészen $10 \mathrm{ng} / \mathrm{ml}$ koncentrációig, és csak ez után kezdett csökkenni a jel, de még így sem érte el az $50 \%$-os gátlást $100 \mathrm{ng} / \mathrm{ml}$ koncentrációnál (30. ábra). A vizsgálat során a pontyminták

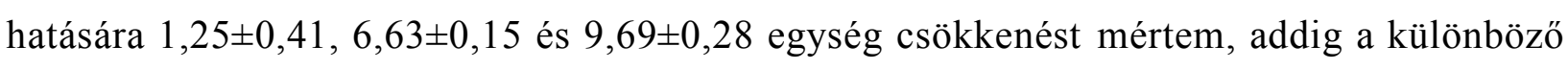
koncentrációjú béka-Lpv fehérjét tartalmazó oldatok esetében lényegesen kisebb, 0,27 $\pm 0,36$, $0,83 \pm 0,20$ és $1,84 \pm 0,15$ egység csökkenést észleltem. A mérés alapján megállapítható, hogy a ponty-Lpv szelektíven mérhető a kifejlesztett OWLS immunszenzorral.

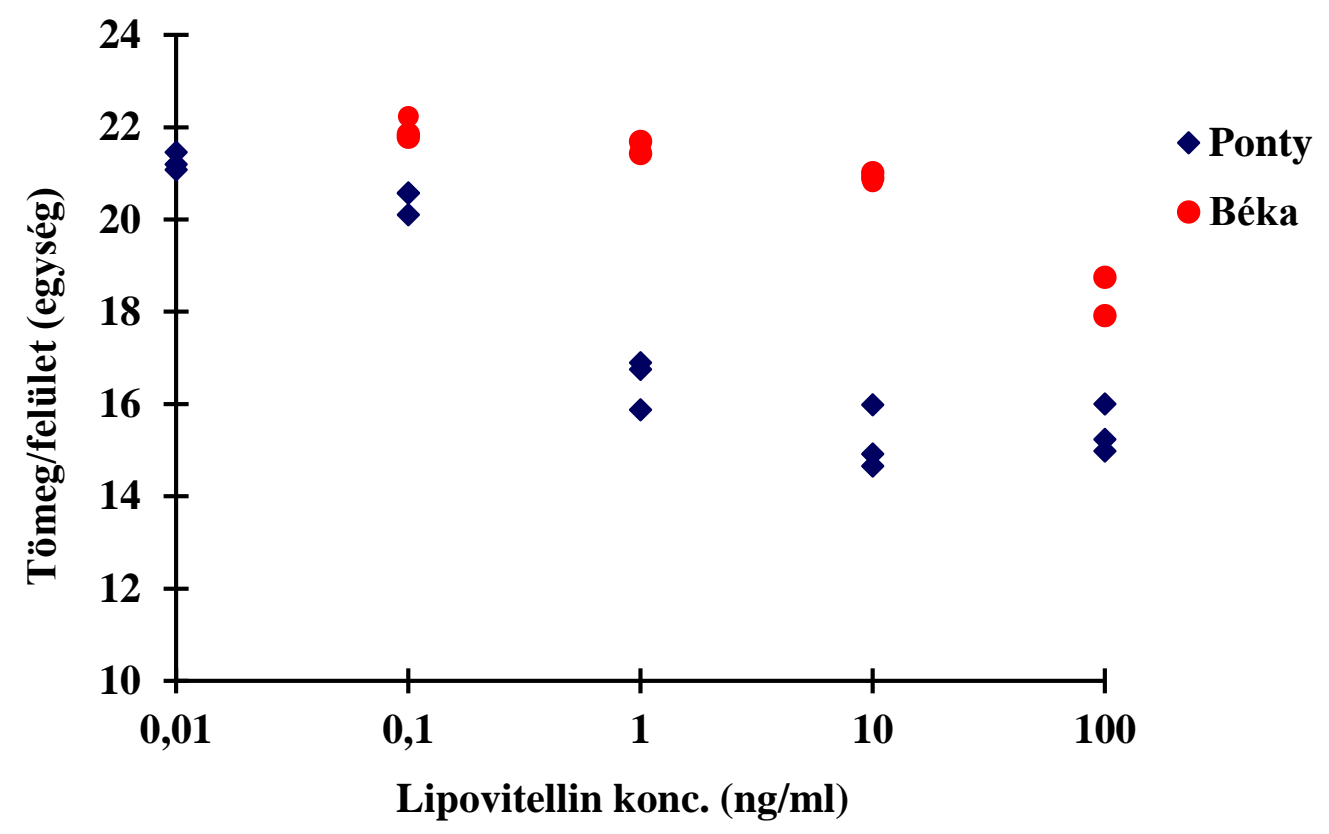

30. ábra Ponty-anti-Lpv szelektivitásának meghatározására készített kalibrációs görbe (5 $\mu \mathrm{g} / \mathrm{ml} \mathrm{Lpv}$ rögzítve, $64,1 \mu \mathrm{g} / \mathrm{ml}$ antitest) 


\subsection{A ponty minták mátrixhatása, Vtg meghatározása biológiai mintákból}

A kialakított kompetitív szenzor biológiai mintáknál történő alkalmazása során számítani kell a biológiai minta zavaró hatásaira. E mártixhatások megjelenhetnek a háttérszint növekedésében melyet a nem specifikus kötések okoznak, a standard kalibrációs görbe felfelé történő eltolódásában. Hogy a mátrixhatást csökkentsem hím ponty vérét mesterségesen szennyeztem különböző mennyiségü (0,01-1000 ng/ml) lipovitelinnel és ezeket a mintákat használtam standardként. A különböző minták vitellogenin tartalmát e kalibrációs görbe alapján határoztam meg, és vizsgáltam a mesterségesen szennyezett Lpv mennyiségek visszanyerési arányát is. Az 1, 10 és $100 \mathrm{ng} / \mathrm{ml}$ Lpv fehérjét tartalmazó vérmintákból a visszamérést 140\%, 89\% és $84 \%$-nak találtam. Vizsgáltam további hím és nőstény pontyok vérszérumában a Vtg mennyiségét a kialakított mérőrendszerrel. Minden minta esetén három párhuzamos mérést végeztem. Eredményeim alapján a hím egyedek Vtg-szintje $0,5 \pm 0,3$, illetve $5,0 \pm 1,8 \mu \mathrm{g} / \mathrm{ml}$ és 6,2 $\pm 0,8$ Vtg-nek adódott, addig a nőstény egyedekben $246,1 \pm 19,6,367,5 \pm 54,7$ és 465,4 446,9 $\mu \mathrm{g} / \mathrm{ml}$ Vtg-t mértem az immunszenzorral.

A pontyok májában levő Vtg koncentrációját is mértem a 4.3.2. fejezetben leírt előkészítés után. Máj vizsgálatánál hasonlóan jártam el, mint a vér vizsgálatánál. A kalibrációhoz vitellogeninmentes hím májat mesterségesen szennyeztem különböző koncentrációban ponty Lpv-nel. A 31. ábrán az így felvett kalibráció látható.

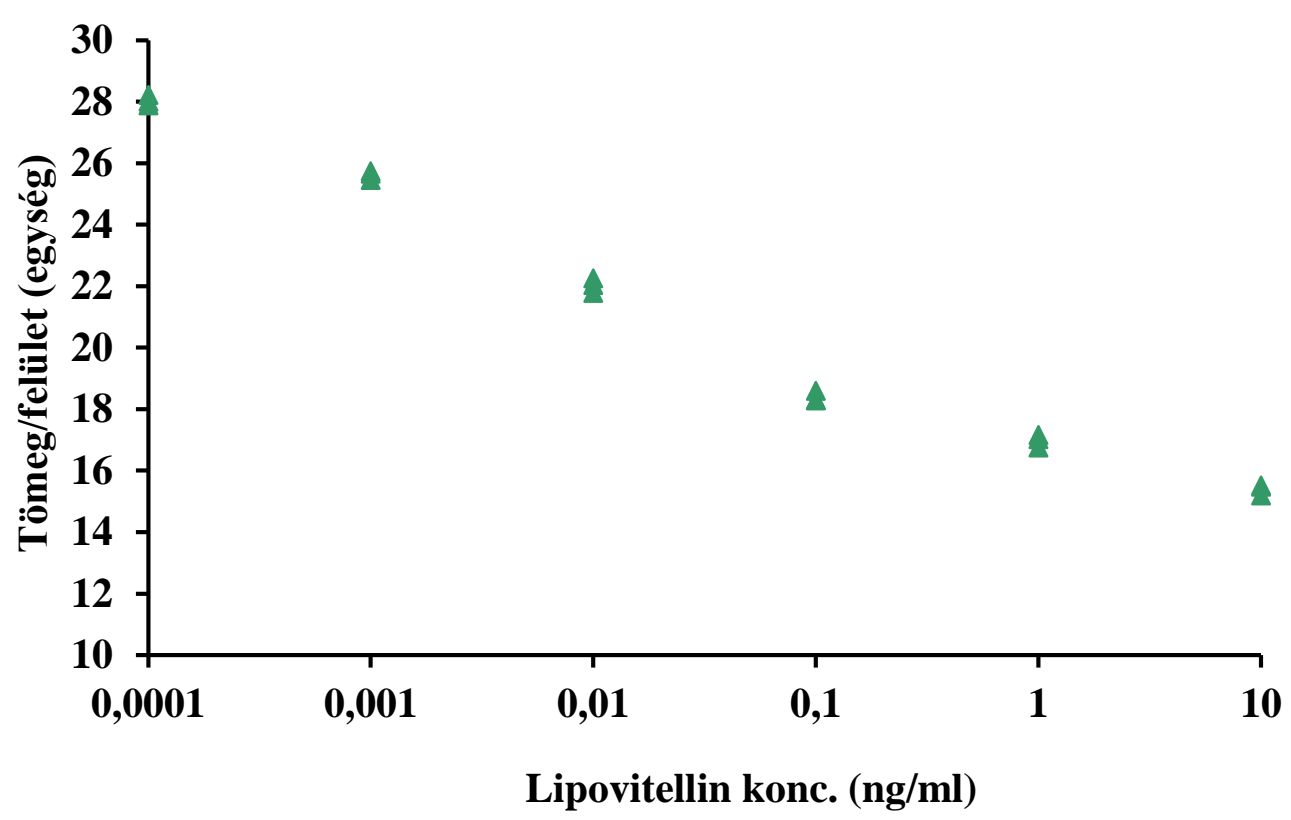

31. ábra Ponty Lpv kalibrációs görbéje indirekt szenzorral máj mintában 
Vizsgáltam a vitellogenin-mentes hím máj mintákat, nőstény máj mintákat és a mátrix mentes, $0 \mathrm{ng} / \mathrm{ml}$ Vtg tartalmú mintát, ami csak az antitestet tartalmazta, megfelelő hígításban. Úgy találtam, hogy a minták mátrixhatása lényegesen nagyobb volt, mint a vérszérumok esetében.

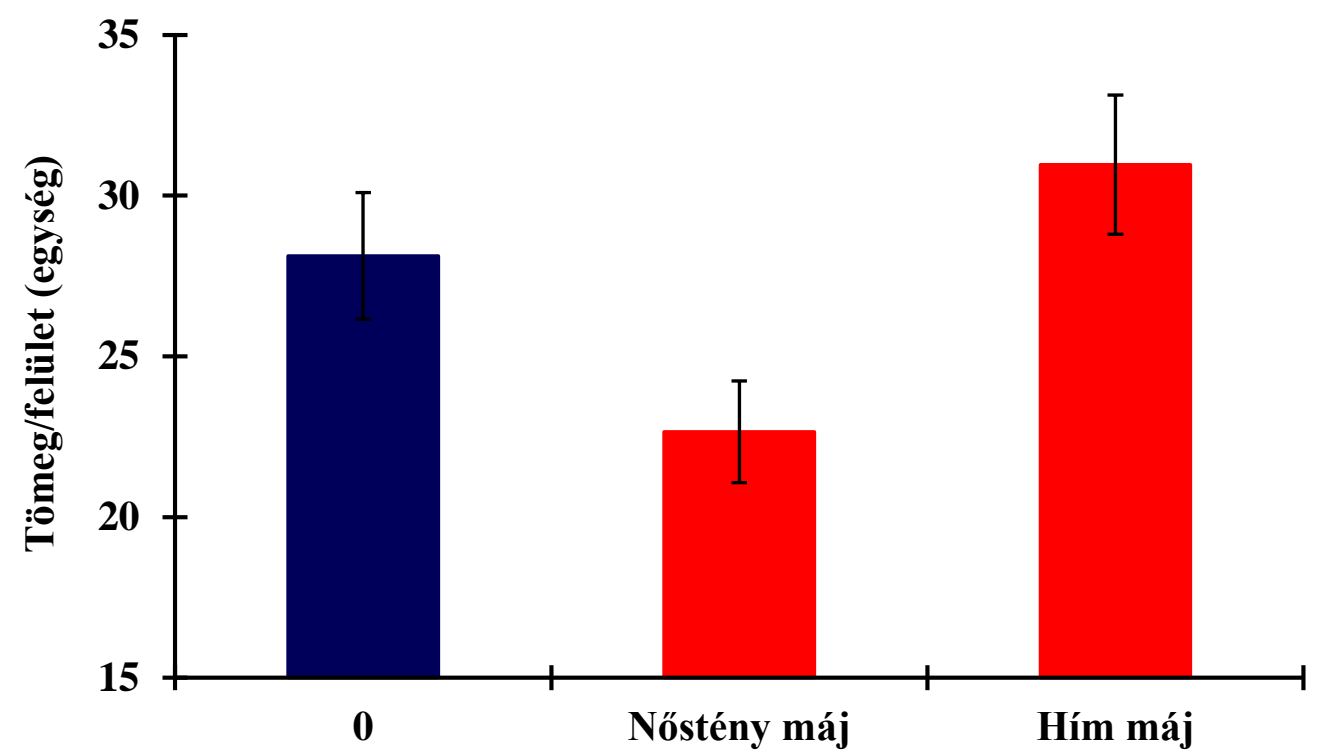

32. ábra Ponty minták mátrixhatása. (0: csak antitestet tartalmazó minta, nőstény máj: nőstény ponty máj + antitest, hím máj: ponty hím máj + antitest

Látható (32. ábra), hogy a legnagyobb jelet a hím egyed mája adta, jóval nagyobbat mint a mátrixmentes minta. Ennek alapján elmondható, hogy a kalibrációhoz mesterségesen szennyezett mintákra van szükség, és az ismeretlen minta meghatározásához mindig a minta mátrixának megfelelően kell a kalibrációt elkészíteni. Ugyanazon hím és nőstény pontyok májának Vtg tartalmát vizsgáltam, mint amelyeknek véréből korábban meghatároztam a vitellogenin mennyiségét. A hím pontyok májában $1,1 \pm 0,7,1,8 \pm 0,7,2,6 \pm 0,9 \mu \mathrm{g} / \mathrm{g}$ Vtg-t mértem, míg a nőstény egyedekben $28,6 \pm 6,3,29,7 \pm 5,4$ és $40,9 \pm 4,7 \mu \mathrm{g} / \mathrm{g}$ Vtg-t mutattam ki. Eredményeim alapján megállapítható, hogy a nőstény egyedek máj mintáinak vitellogenin tartalma kevesebb volt, mint a vérből történő meghatározás esetén, ezért a vér vizsgálata megfelelőbb lehetőséget biztosít a hím pontyok megemelkedett Vtg szintjének vizsgálatára, mely a felszíni vizek EDCs-vel való szennyezése miatt alakulhat ki. Annak ellenére, hogy a szennyező anyag eredetét a biológiai hatás alapú monitorozással nem tudom meghatározni, az általam kifejlesztett új kompetitív OWLS alapú immunszenzor alkalmas lehet a vizek esetleges szennyezettségének gyors és megbízható jelzésére. 


\subsubsection{Immunszenzor fejlesztése béka vitellogenin kimutatásra}

\subsubsection{Szenzorfelület módosítása, fehérjék immobilizálása}

Béka Vtg kimutatására alkalmas szenzor fejlesztésénél a glutáraldehides rögzítéstől eltérő felületmódosítási és immobilizációs technikát alkalmaztam. A vizsgálataimban az aminoszilanizált szenzor felületén lévő aminocsoportokat karboxil csoportokra módosítottam, majd a 4.2.3 fejezetben említett EDC/NHS-sel immobilizáltam a biológiailag aktív anyagokat. Mérésnél a biológiailag aktív anyaggal érzékenyített kész szenzort helyeztem be a készülékbe, 42 mM-os pH 7,4-es TRIS pufferrel mostam a felületét, majd a szabad reaktív szukcinimid észter csoportokat 0,1 M-os etanolamin injektálásával blokkoltam. Pufferes mosást követően 0,05 M-os sósavval eltávolítottam a lazán kötődő molekulákat és a szenzor készen állt a mérésre. Ez az eljárás jelentősen lerövidíti az előkészítést, hisz az előkészített szenzorfelületen a mérést azonnal meg lehet kezdeni.

\subsubsection{Direkt mérési módszer béka vitellogenin mérésére}

Dierekt szenzor kialakításánál a karboxilcsoportokkal módosított szenzorokat használtam fel, mely felszínére EDC/NHS technikával rögzítettem a poliklonális antitestet különböző koncentrációban $(17,6 ; 8,8 ; 3,52 ; 1,76 ; 0,88 \mu \mathrm{g} / \mathrm{ml})$, és vizsgáltam a béka Lpv standardokra adott válaszjel nagyságát. Abban az esetben, amikor a szenzor felületén túl sok antitestet rögzítettem $(8,8$ és $17,6 \mu \mathrm{g} / \mathrm{ml})$, a szenzor felületére rögzített réteg vastag lett, így a

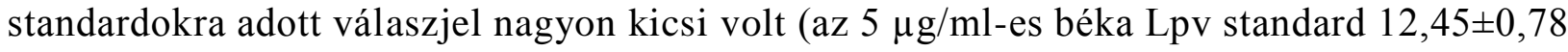
egységnyi jelet adott). A legérzékenyebb szenzort a $0,88 \mu \mathrm{g} / \mathrm{ml}$ antitest rögzítésével értem el, de ebben az esetben az eredmények nem voltak reprodukálhatóak, mert a szenzor felületén túl kevés molekula került rögzítésre. A vizsgálataim során az 1,76 $\mu \mathrm{g} / \mathrm{ml}$ fehérjét tartalmazó szérumot alkalmazva jól értékelhető görbéket kaptam, így a direkt szenzor kialakításánál a továbbiakban $1,76 \mu \mathrm{g} / \mathrm{ml}$ koncentrációban rögzítettem a poliklonális szérumot. A 33. ábra az így kialakított direkt szenzor kalibrációs görbéjét mutatja be. 


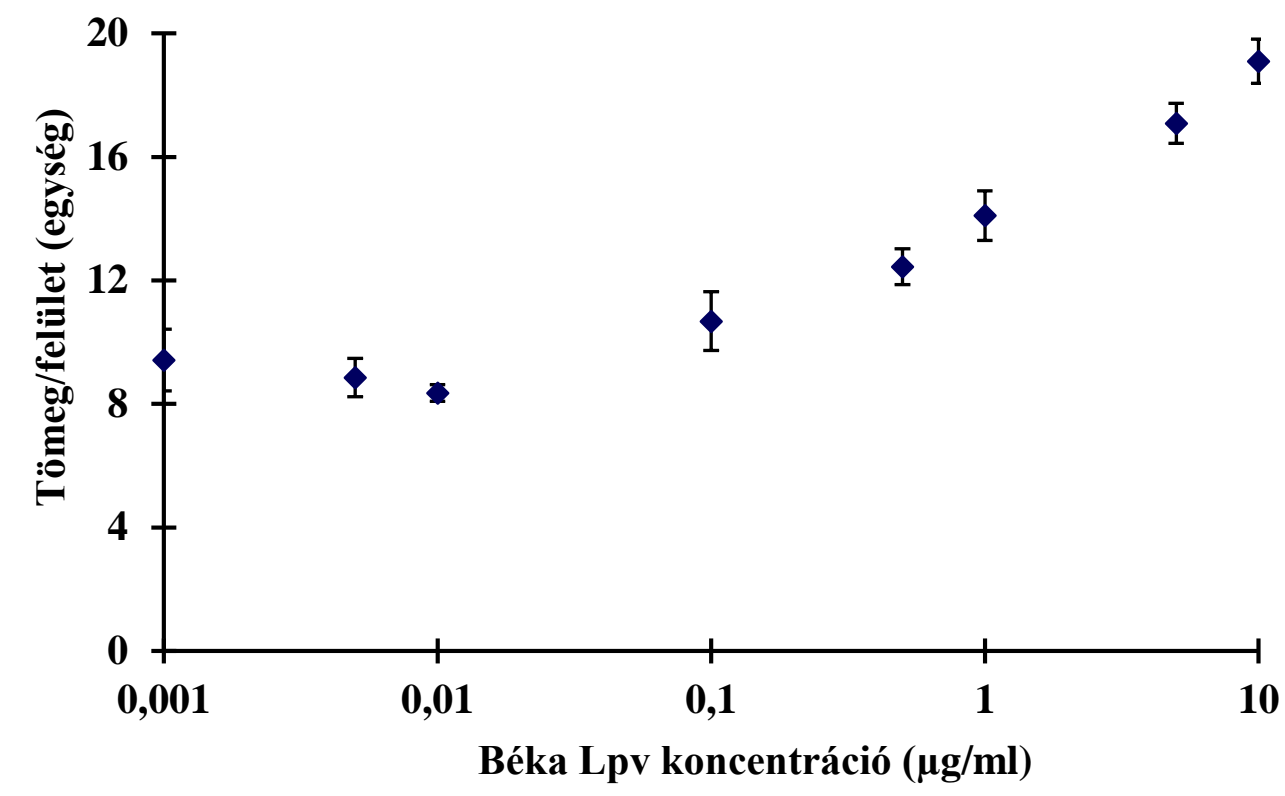

33. ábra A direkt szenzor kalibrációs görbéje $1,76 \mu \mathrm{g} / \mathrm{ml}$ szérum rögzítése esetén (szigmoidillesztés, $\chi^{2} /$ szabadsági fok $=0,95 ; \mathrm{R}^{2}=0,99$ )

A direkt szenzor dinamikus méréstartománya $0,1-10 \mu \mathrm{g} / \mathrm{ml}$ vitellogenin volt, míg a szenzor

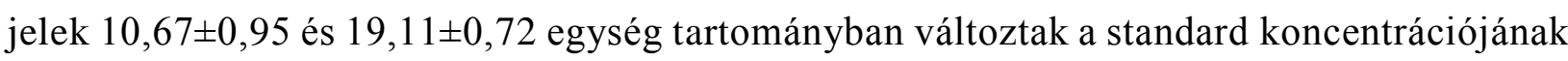
megfelelően. A béka Lpv kimutatási határa $50 \mathrm{ng} / \mathrm{ml}$ volt. Ez a méréstartomány igen magas, nem alkalmas a béka vitellogenin szint meghatározásra, ezért vizsgáltam a kompetitív mérési rendszer kialakításának lehetőségét az érzékenység növelése érdekében.

\subsubsection{Kompetitív immunszenzor kifejlesztése béka vitellogenin meghatározáshoz}

Karboxilcsoportokat tartalmazó szenzorok felhasználásával, EDC/NHS rögzítési módszert alkalmazva, béka vitellogenin meghatározására alkalmas kompetitív immunszenzort alakítottam ki.

\subsection{Alkalmazott poliklonális antitest koncentrációjának meghatározása}

Vizsgálatomban a szenzor felületére kovalens kötéssel $100 \mathrm{ng} / \mathrm{ml}$ tisztított béka-Lpv fehérjét rögzítettem, majd 50 mM-os sósavval történö regenerálás után a szérumot 0,$88 ; 1,17 ; 1,76$; 2,22; 3,52; 8,8 és 17,6 $\mu \mathrm{g} / \mathrm{ml}$ koncentrációban injektáltam a rendszerbe. Az eredmények alapján megállapítottam, hogy kis antitest koncentráció mellett $(0,88$ és $1,76 \mu \mathrm{g} / \mathrm{ml})$ a szenzor érzékenysége nagy volt, de a szenzorjelek igen kicsik (9-14 egység), összemosódtak a válaszjelek. Nagyobb antitest koncentráció $(3,52-17,6 \mu \mathrm{g} / \mathrm{ml})$ alkalmazásával a szenzor válaszjel nagysága nőtt (26-39 egység), ugyanakkor a teszt érzékenysége csökkent. Az 34. ábra a béka anti-Lpv antitest titrálási görbéit mutatja be. 




34. ábra Optimális antitestkoncentráció meghatározása kompetitív OWLS méréshez (immobilizált béka-Lpv koncentráció 100 ng/ml)

Fontos, hogy a további méréseket olyan antitest koncentráció alkalmazásával kell végezni, ahol a szenzor válasz jól értékelhető, ugyanakkor az érzékenység is megfelelö. Az eredmények alapján, a válaszjelek nagyságának és lefutásának figyelembevételével, béka Vtg kompetitív meghatározásához a poliklonális antitest oldatot a továbbiakban $2,22 \mu \mathrm{g} / \mathrm{ml}$ koncentrációban alkalmaztam, mely 21 egységnyi válaszjelet adott.

\subsection{A rögzített antigén optimális koncentrációjának meghatározása}

Különböző hígítású béka lipovitellint (1 ng/ml, $10 \mathrm{ng} / \mathrm{ml}, 50 \mathrm{ng} / \mathrm{ml}, 100 \mathrm{ng} / \mathrm{ml}$, $200 \mathrm{ng} / \mathrm{ml}$ ) rögzítettem a karboxilcsoportokat tartalmazó szenzor felületén EDC/NHS eljárással és vizsgáltam a szérum hígított oldatára és a standardokra adott válaszjel nagyságát. Ha nagyon kis mennyiségü fehérjét rögzítettem a felszínen (1-10 ng/ml), akkor nagyon kevés antitest molekula tudott kötődni, kis jeleket kaptam. Ugyanakkor, ha túl sok fehérjét rögzítettem (200 ng/ml), nem kaptam nagyobb jeleket, feltehetően a sztérikus gátlás miatt. Kísérleteim további részében $100 \mathrm{ng} / \mathrm{ml}$ koncentrációjú fehérje oldattal érzékenyítettem a szenzor felületét. Az így kialakított szenzorral béka-Lpv fehérjét vizsgálva 0,001-1000 ng/ml méréstartományban készítettem kalibrációs görbét. A dinamikus méréstartomány 0,5-10 ng/ml értékủnek adódott, a Lpv kimutatásának alsó határára 0,1






\subsection{Béka lipovitellin antitest szubsztrátspecifitása}

A vizsgálatban béka-Lpv fehérjével érzékenyített immunszenzorral összehasonlítottam, hogy 0,$1 ; 1,0 ; 10$ és $100 \mathrm{ng} / \mathrm{ml}$ ponty- illetve béka-Lpv fehérjét tartalmazó oldatok mekkora jelcsökkenést okoznak. A szenzor felületén 100 ng/ml béka Lpv-t rögzítettem kovalensen, és a béka anti-Lpv antitestet 2,22 $\mu \mathrm{g} / \mathrm{ml}$ koncentrációban alkalmaztam. Megállapítottam, hogy a pontyLpv a béka-Lpv jeléhez képest $17,7 \pm 5,2 \%, 12,7 \pm 6,1 \%, 3,3 \pm 1,3 \%$ és 4,9 $9 \pm 1,0 \%$, jelcsökkenést eredményezett, tehát a béka-Lpv ellen termeltetett antitest is szelektíven köti a fajspecifikus antigén fehérjét (35. ábra).

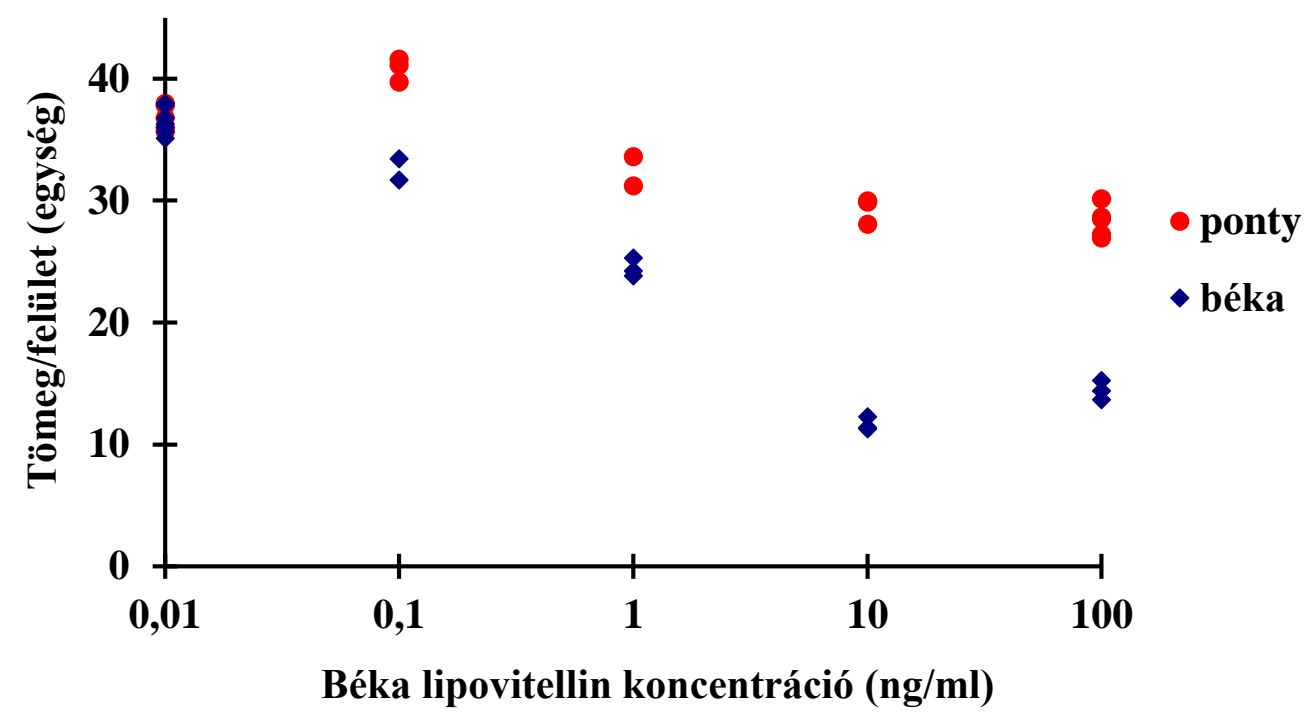

35. ábra Béka-anti-Lpv szelektivitásának meghatározására készített kalibrációs görbe $(0,1$ $\mu \mathrm{g} / \mathrm{ml} \mathrm{Lpv}$ rögzítve, $2,22 \mu \mathrm{g} / \mathrm{ml}$ antitest)

\subsection{Biológiai minták mátrixhatása}

A kompetitív szenzor kialakítását követően a 4.3.3 fejezetben leírtak szerint előkészített biológiai mintákat vizsgáltam. A metodika kialakításának meghatározó eleme a vitellogenint nem tartalmazó mátrix kiválasztása volt. Erre a célra hím vöröshasú unka májextraktumát használtam, mely nem tartalmaz vitellogenint. Alternatívaként használható hím pontyból származó májextraktum is, még akkor is, ha enyhe Vtg szint emelkedés tapasztalható az egyednél, hisz a béka lipovitellin ellen termeltetett szérum igen kicsi keresztreakciót mutatott a ponyt lipovitelinnel, így a vizsgálat során interferencia nem valószínű (lsd. 5.3.3.3.3. fejezet). A kalibrációs standardok elkészítéséhez hím májextraktumot mesterségesen szennyeztem vöröshasú unkából tisztított lipovitelinnel. A kialakított mintákat különböző hígításban (1000-szeres, 5000- 
szeres, 10000-szeres) vizsgáltam annak érdekében, hogy az optimális méréstartományt meghatározzam (36. ábra). A minták hígításához 42 mM-os pH 7,4-es TRIS puffert alkalmaztam.

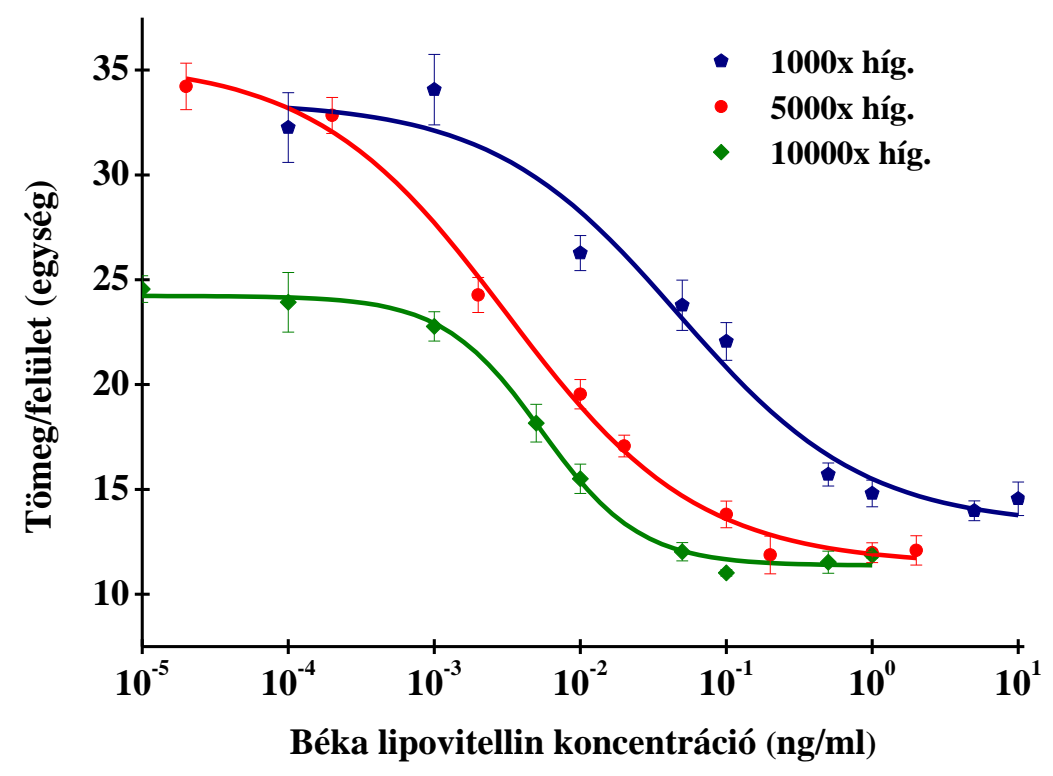

36. ábra A békamáj extraktumba mesterségesen szennyezett Lpv mérésének kalibrációs görbéje (a minták hígítása: 1000, 5000 és 10000-szeres; $\mathrm{IC}_{50}$ 0,46; 0,031;0,055 ng/ml)

Az 1000-szeresen hígított mesterségesen szennyezett májminták alkalmazásakor a szenzor igen nagy válaszjeleket adott, ami a mátrixhatásnak tudható be, ugyanakkor a szenzor élettartama drasztikusan lecsökkent és a méréstartomány is beszükült. Az 5000-szeresen hígított minták mérésekor megfelelő jeleket kaptam 0,001-1 ng/ml koncentrációtartományban, míg a 10000szeresen hígított minták már túlságosan hígnak bizonyultak. A továbbiakban a biológiai mintákat 5000-szeres hígításban vizsgáltam a kialakított kompetitív OWLS szenzorral.

\subsection{Biológiai minták vizsgálata}

A vitellogenin monitorozását elsősorban vérből történő Vtg tartalom meghatározásával végzik. A béka minták vizsgálatánál tekintettel kellett lenni arra, hogy a vizsgált keleti unka (Bombina orientalis) és európai vöröshasú unka (Bombina bombina) fiatal egyedei igen kicsik, ezért nem lehetett csak vérmintából dolgozni, hanem a szív és vér együtt került feldolgozásra a minta készítése során a 4.3.3. fejezetben leírtak szerint. Ismeretlen mintaként nőstény és hím egyedek máj-, szív- és vér- illetve ivarmirigy-preparátumából vizsgáltam a természetes Vtgszintet. A vizsgálathoz a kialakított kompetitív OWLS immunszenzort alkalmaztam, ahol a szenzor felületén $100 \mathrm{ng} / \mathrm{ml}$ béka lipovitelint rögzítettem, a poliklonális szérumot 2,22 $\mu \mathrm{g} / \mathrm{ml}$ koncentrációban alkalmaztam. Az alkalmazott áramlási sebesség $0,08 \mathrm{ml} /$ perc volt. A mintákat 20 
${ }^{\circ} \mathrm{C}$-on 1 percig inkubáltam és injektáltam a rendszerbe. A szenzor mintatartó küvettájának hőmérsékletét szintén $20{ }^{\circ} \mathrm{C}$-ra állítottam be. E paraméterek mellett végeztem el a minták vizsgálatát melynek eredményeit a 4. táblázat foglalja össze. A kísérletben az OWLS immunszenzorral kapott eredményeket ELISA módszerrel mért koncentrációkkal hasonlítottam össze.

4. táblázat: Vöröshasú unka (Bombina bombina) szerveiben kimutatható Vtg koncentrációja immunszenzorral és ELISA módszerrel mérve

\begin{tabular}{|l|l|c|c|c|c|}
\hline Szövet & OWLS $^{\mathrm{a}}$ & $\begin{array}{c}\text { Minta Vtg- } \\
\text { koncentrációja }\end{array}$ & ELISA $^{\mathrm{b}}$ & $\begin{array}{c}\text { Minta Vtg- } \\
\text { koncentrációja }\end{array}$ \\
\hline máj & nőstény & $27,0 \pm 1,2$ & $135,0 \pm 6,0$ & $87,1 \pm 7,9$ & $130,7 \pm 7,9$ \\
\hline & hím & $12,5 \pm 3,6$ & $62,5 \pm 18,0$ & n.d. $^{\text {c }}$ & .d. $^{\text {c }}$ \\
\hline szív / vér & nóstény & $37,3 \pm 2,8$ & $186,5 \pm 14,0$ & $132,3 \pm 11,2$ & $198,5 \pm 11,2$ \\
\hline & hím & $26,4 \pm 5,6$ & $132,0 \pm 28,0$ & $86,2 \pm 10,1$ & $129,3 \pm 10,1$ \\
\hline ivarmirigy & $\begin{array}{l}\text { nóstény } \\
\text { (petefészek) }\end{array}$ & $150,9 \pm 14,7$ & $754,5 \pm 73,5$ & $338,7 \pm 65,5$ & $508,1 \pm 98,3$ \\
\hline & hím (here) & n.d. $^{c}$ & n.d. $^{c}$ & n.d. $^{c}$ & n.d. $^{\text {c }}$ \\
\hline pete & & $206,1 \pm 59,7$ & $1030,0 \pm 298,5$ & $616,7 \pm 91,0$ & $925,0 \pm 136,5$ \\
\hline
\end{tabular}

a 1:5000 hígításban mérve

b 1:1500 hígításban mérve

c mátrixhatás

Vizsgálataimban ELISA módszerrel csak $100 \mathrm{ng} / \mathrm{ml}$ körüli vitellogenin koncentrációt tudtam kimutatni 1:1500 arányú mintahígítást alkalmazva, míg a kompetitív OWLS módszerrel $10 \mathrm{ng} / \mathrm{ml}$ fölötti vitellogenin szintet sikerült kimutatni 1:5000 arányú mintahígításnál. A vizsgált minták közül a legmagasabb értékeket a várakozásnak megfelelően a petefészekböl és a petéből mértem $(754,5 \pm 73,5$ és $1030,0 \pm 298,5 \mu \mathrm{g} / \mathrm{g})$. A here minták a nagy mátrixhatás miatt nem vizsgálhatók. Eredményeim alapján megállapítottam, hogy az általam kifejlesztett kompetitív immunszenzor alkalmas béka Vtg fehérjéjének kimutatására. 


\section{6. ÚJ TUDOMÁNYOS EREDMÉNYEK}

> Modellkísérletekkel bebizonyítottam, hogy a felületmódosítási és rögzítési lépések a mérések során reprodukálhatóak. Vizsgáltam a rögzítés során a szenzorválasz nagyságát az analitikum molekulatömege és koncentrációja függvényében, mely során megállapítottam, hogy a szenzor válaszjel nagysága arányos a molekulatömeggel, illetve a szenzorválasz nagysága lineárisan nő az adott analitikum koncentrációjának növelésével.

Kompetitív, jelölésmentes immunszenzort fejlesztettem ki DON meghatározására búzamintákból. A kialakított szenzorral a méréstartomány két nagyságrenddel kisebb, mint az általam létrehozott OWLS direkt szenzor esetében, és közel egy nagyságrenddel kisebb, mint ami a hasonló immunszenzorokkal SPR detektálással elérhető. A mesterségesen szennyezett búzalisztből a DON mikotoxint a minta-előkészítés során 91,6-123,0\%-ban nyertem vissza, mely eredmények alapján az általam kifejlesztett kompetitív jelölésmentes immunszenzor sikeresen alkalmazható DON búzából történő kimutatására.

Sikeresen dolgoztam ki versengő immunszenzort OWLS detektálással hal (ponty, Cyprinus carpio) vitellogenin fehérje kimutatására. A szenzor kialakításához a Vtg fehérjénél könnyebben izolálható és a Vtg fehérjével az azonos fajban 95\% keresztreakciót mutató Lpv fehérjét alkalmaztam. A kialakított szenzorral hím és nőstény pontyok vérmintáinak vitellogenin tartalmát vizsgáltam. Eredményeim alapján megállapítottam, hogy a felszíni vizek EDC-vel történő szennyezése miatt a hím egyedek vérében megemelkedett Vtg szint monitorozására az általam kialakított szenzor eredményesen használható.

Elsőként dolgoztam ki szelektív, kompetitív OWLS immunszenzoros mérési eljárást vöröshasú unka (Bombina bombina) Vtg fehérjéjének meghatározására. Nőstény és hím békaegyedek máj-, szív-, vér-, illetve ivarmirigy-preparátumából vizsgáltam a természetes Vtg-szintet, majd eredményeimet ELISA referencia-módszerrel hasonlítottam össze. Eredményeim alapján megállapítottam, hogy az általam kialakított szenzor érzékenysége egy nagyságrenddel nagyobb az ELISA módszer érzékenységéhez képest, így a kifejlesztett immunszenzor alkalmas vizes élőhelyek endokrin zavaró hatású anyagokkal való szennyezettségének monitorozására. 


\section{KÖVETKEZTETÉSEK, JAVASLATOK}

Munkám során OWLS alapú immunszenzorokat fejlesztettem ki élelmiszer- és környezetanalitikai felhasználásra. A kísérletek során megállapítottam, hogy a DON kimutatására alkalmas szenzor fejlesztése esetén a direkt vizsgálati módszer alkalmazása nem volt megfelelő, hiszen a vizsgálandó analitikumok molekulatömege jóval kisebb volt az antitesténél, így a direkt mérés esetén kis koncentrációban a felületre kötött analitikum által létrehozott tömegváltozás elenyésző, az elérhető érzékenység messze elmaradt a követelményektől. A Vtg kimutatására kialakított direkt szenzorok dinamikus méréstartománya igen magas volt, így ezekben az esetekben is kompetitív szenzor kialakítására volt szükség.

Versengő immunszezort fejlesztettem ki OWLS detektálással DON, illetve hal és béka eredetű vitellogenin fehérjék kimutatására. Eredményeim alapján megállapítottam, hogy a DON vizsgálatára kialakított immunszenzor érzékenysége megfelelő volt, így alkalmas az Európai Unióban elöírt követelmények szerint DON gabonából történő kimutatására. Megállapítottam, hogy a kifejlesztett kompetitív immunszenzoros mérési eljárás alkalmas hal (ponty, Cyprinus carpio) és béka (vöröshasú unka, Bombina bombina) vitellogenin fehérjéinek kimutatására. A hím egyedekben mérhető Vtg-szint alapján feltehetően monitorozni lehet a felszíni vizek, illetve vizes élőhelyek hormonális működésre ható anyagokkal való szennyezettségét.

$\mathrm{Az}$ optimalizált mérőrendszerekkel valós minták vizsgálatát végeztem el. DON kimutatására alkalmas immunszenzorral mesterségesen szennyezett búzaminták DON tartalmát határoztam meg. Az eredmények alapján megállapítottam, hogy a búzalisztből a DON mikotoxint a minta-előkészítés során 91,6-123,0\%-ban nyertem vissza, a minta-előkészítés és az immunszenzorral végzett meghatározás alkalmas DON búzából történő kimutatására. Vitellogenin kimutatására alkalmas immunszenzorral hím és nőstény ponty egyedek vérmintáiból, valamint nőstény és hím békaegyedek máj-, szív- és vér-, illetve ivarmirigy-preparátumából vizsgáltam a természetes vitellogenin-szintet. A kompetitív OWLS immunszenzorral mért Vtg eredményeket ELISA módszerrel hasonlítottam össze. Ezen eredmények alapján megállapítható, hogy szelektivitás tekintetében eredményeim megfelelnek a versengő ELISA módszerek szelektivitásának, a kimutatási határ azonban több nagyságrenddel kisebb, mint a hasonló biológiai, biokémiai rendszert alkalmazó eljárásé.

\section{A továbbiakban a következö feladatok elvégzését javasolnám:}

Munkám során DON meghatározására alkalmas OWLS alapú indirekt immunszenzort fejlesztettem ki. A kutatás folytatásaként különböző helyről pl.: gabonaátvételi helyszínekről 
származó ismeretlen búzaminták, valamint DON-nal szennyezett élelmiszerminták (pl.: tészták, kenyerek stb.) vizsgálatát kellene elvégezni a kialakított szenzorral és az eredményeket HPLC-MS referenciamódszerrel hasonlítanám össze. Érdemes volna a kialakított szenzorral más mátrixokból (pl.: kukoricából, árpából) történő DON meghatározást végezni.

A biomarkerként használt Vtg kimutatására alkalmas szenzorfejlesztéseinknél további vizsgálatként érdemes lenne az OWLS szenzor eredményeit más immunszenzor technikákkal összehasonlítani, mint pl. QCM, vagy SPR alkalmazásával.

A szenzorokat különböző ismert EDCs-vel (biszfenol-A, dibutil-ftalát, butil-benzil-ftalát, di(2-etilhexil)-ftaláttal) szennyezett vízben nevelt halak illetve békák vizsgálatára alkalmaznám, a környezeti szennyezések hatásának modellezése érdekében.

A szenzorfejlesztési munkák folytatásaként az OWLS immunszenzor további alkalmazási lehetőségeit vizsgálnám egyéb kis molekulsúlyú analitikumok, illetve fehérjék kimutatására. 


\section{8. ÖSSZEFOGLALÁS}

Munkám célja OWLS alapú immunszenzorok kifejlesztése volt élelmiszer és környezetanalitikai alkalmazásra. Egyrészt DON kimutatására alkalmas immunszenzort fejlesztettem ki, és a kialakított szenzorral búzaminták DON tartalmát határoztam meg. Másrészt felszíni vizek EDCs-vel történő szennyezésének kimutására biomarkerként használható, vitellogenin kimutatására alkalmas szenzorokat alakítottam ki vöröshasú unka (Bombina bombina) és ponty (Cyprinus carpio) mintákból történö kimutatásra.

A szenzorok kialakításához először modellkísérletekben vizsgáltam az OWLS szenzorjelek változását annak érdekében, hogy bebizonyítsam, a felületmódosítási és rögzítési lépések reprodukálhatóak. Kísérleteimben vizsgáltam a szenzor felületének módosítása, valamint a rögzítés során bekövetkezett rétegvastagságbeli változásokat. Megállapítottam, hogy a kezeletlen hullámvezető rétegvastagsága 170-200 nm közt van, ezt az APTS-sel történő módosítás

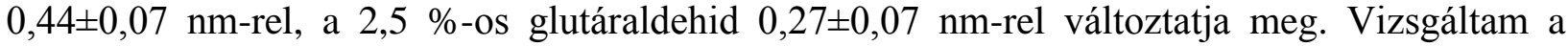
szenzorválasz nagyságát az analitikum molekulatömege és koncentrációja függvényében, mely során megállapítottam, hogy a szenzor válaszjel nagysága arányos a molekulatömeggel, illetve a szenzorválasz nagysága lineárisan nő az adott analitikum koncentrációjának növelésével. Vizsgáltam a szenzorválasz reakcióidejét és az érzékelés pontosságát a chip $T_{E}$ és $T_{M}$ becsatolási szögeinek variabilitását vizsgálva. Eredményeim alapján átlagosan az $\alpha_{\mathrm{TM}}=0,724627 \pm 0,0000824$ (relatív hiba $0,011 \%$ ), míg a $\alpha_{\mathrm{TE}}=3,197883 \pm 0,000157$ (relatív hiba $0,005 \%$ ) volt, mely igen pontos érzékelést tesz lehetővé. Megállapítottam, hogy a beállítási protokolltól függően percenként 4-10 mérési pont felvétele lehetséges, mely adatszolgáltatási sebesség alkalmas a reakciók valós idejü monitorozására.

Munkám során indirekt immunszenzort fejlesztettem ki deoxynivalenol (DON) mikotoxin meghatározására búzamintákból. A DON mikotoxinból nátrium-perjodátos kezelés után konjugátumot készítettem OVA és BSA felhasználásával. A DON-OVA konjugátum segítségével poliklonális antitestet állítottam elő. A biomolekulák alkalmazásával versengő immunszenzort fejlesztettem ki. Az optimalizált müködési paraméterek mellett a DON-standardokat vizsgálva a


( $\chi^{2} /$ szabadsági fok $\left.=1,57 ; \mathrm{r}^{2}=0,99\right)$, a kimutatás alsó határa $0,001 \mathrm{ng} / \mathrm{ml}$ értékünek adódott. $\mathrm{A}$ deoxynivalenollal szennyezett búzalisztmintákkal nyert kalibrációs görbe alapján a dinamikus méréstartomány a lisztmintára számolva $0,005-50 \mathrm{mg} / \mathrm{kg}$ volt, a gátlási középérték ( $\mathrm{IC}_{50}$ ) $0,13 \pm 0,04 \mathrm{mg} / \mathrm{kg}$ értékünek adódott, a visszanyerés pedig $90 \%$ feletti volt, így a szenzor megfelel az Európai Unióban érvényes határérték követelmények szerint DON búzából történő 
kimutatására. (Az Európai Bizottság a DON maximális szintjét $1750 \mu \mathrm{g} / \mathrm{kg}$-on szabályozta feldolgozatlan durumliszt, kukorica, zab esetén (EC reg. No.1881/2006).)

Versengő immunszenzort fejlesztettem ki OWLS detektálással hal (ponty, Cyprinus carpio), és béka (vöröshasú unka, Bombina bombina) eredetü Vtg fehérje kimutatásra. A vizsgálathoz a Vtg fehérjénél könnyebben izolálható és a Vtg fehérjével az azonos fajban 95\% keresztreakciót mutató Lpv fehérjét alkalmaztam. A Lpv tisztítása nőstény ponty és keleti unka petefészkéből történt. A tisztított Lpv fehérjékkel nyulakat immunizálva antitestet termeltettem. A tisztított Lpv fehérjék és az antitestek alkalmazásával alakítottam ki az immunszenzorokat. Ponty Vtg vizsgálatához kompetitív mérési módszert alkalmaztam, ahol a szenzor felületét $5 \mu \mathrm{g} / \mathrm{ml}$ koncentrációjú Lpv oldattal érzékenyítettem, a mérésekhez 64,1 $\mu \mathrm{g} / \mathrm{ml}$ koncentrációjú poliklonális antitestet használtam. A müködési paraméterek optimalizálását követően a méréseket $20{ }^{\circ} \mathrm{C}$-on 3 perc inkubációval $0,08 \mathrm{ml} /$ perc áramlási sebesség alkalmazása mellett végeztem. A ponty-Lpv fehérjét vizsgálva kalibrációs görbét készítettem, melynek dinamikus méréstartománya 3 és 150 ng/ml Lpv közé esett, a gátlási középérték $\left(\mathrm{IC}_{50}\right)$ 21,18 $\pm 2,86 \mathrm{ng} / \mathrm{ml}$, a kimutatás alsó határa 0,7 ng/ml értékünek adódott. Ökológiai tenyésztésből származó hím és nőstény pontyok vérszérumában vizsgáltam a Vtg-szintet, valamint vizsgáltam a mesterségesen szennyezett Lpv

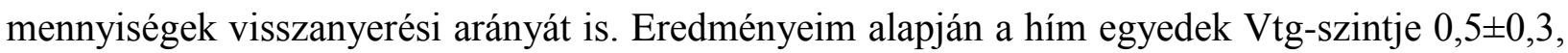
$5,0 \pm 1,8$ illetve $6,2 \pm 0,8 \mu \mathrm{g} / \mathrm{ml}$ volt, míg a nőstény egyedekben $246,1 \pm 19,6,367,5 \pm 54,7$ és $465,4 \pm 46,9 \mu \mathrm{g} / \mathrm{ml} \mathrm{Vtg}$ fehérjét mértem az immunszenzorral. A pontyok májában levő Vtg koncentrációját is mértem. Úgy találtam, hogy a minták mátrixhatása lényegesen nagyobb volt, mint a vérszérumok esetében. A hím pontyok májában $1,1 \pm 0,7 ; 1,8 \pm 0,7$ és $2,6 \pm 0,9 \mu \mathrm{g} / \mathrm{g}$ Vtg-t

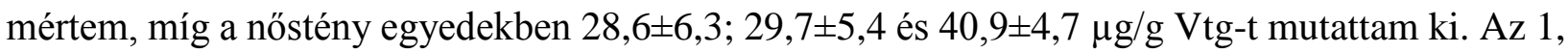
10 és $100 \mathrm{ng} / \mathrm{ml} \mathrm{Lpv} \mathrm{fehérjét} \mathrm{tartalmazó} \mathrm{vérmintákból} \mathrm{a} \mathrm{visszamérést} \mathrm{140 \% ,} \mathrm{89 \%} \mathrm{és} \mathrm{84 \% -nak}$ találtam. Az eredmények alapján megállapítható, hogy a kifejlesztett immunszenzor alkalmas a Vtg-koncentráció hím pontyok vérében történő mérésére.

Béka Vtg kimutatására alkalmas kompetitív immunszenzor fejlesztésénél a karboxil csoportot tartalmazó szenzor felületén $100 \mathrm{ng} / \mathrm{ml}$ koncentrációjú béka Lpv fehérjét EDC/NHS eljárással rögzítettem. A poliklonális antitestet $2,22 \mu \mathrm{g} / \mathrm{ml}$ hígításban alkalmaztam. A béka-Lpv fehérjét vizsgálva a szenzor dinamikus méréstartománya 0,5-10 ng/ml értékünek adódott. Az Lpv


kaptam. Nőstény és hím békaegyedek máj-, szív-, vér-, illetve ivarmirigy-preparátumából vizsgáltam a természetes Vtg-szintet. A minták közül a legnagyobb koncentrációt a petefészekben és a petében találtam $(754,5 \pm 73,5$ és $1030,0 \pm 298,5 \mu \mathrm{g} / \mathrm{g})$.

Eredményeim alapján megállapítható, hogy az immunszenzoros mérési eljárás alkalmas hal (ponty, Cyprinus carpio) és béka (vöröshasú unka, Bombina bombina) Vtg fehérjéjének 
kimutatására. A hím egyedekben mérhető Vtg-szint alapján feltehetően monitorozni lehet a felszíni vizek, illetve vizes élőhelyek hormonrendszert zavaró hatású szermaradványokkal való szennyezettségét.

Kísérleteim során minden esetben a szenzorfejlesztés volt a fő cél. Megállapítható, hogy az általam kialakított OWLS alapú immunszenzorok szelektivitás tekintetében megfelelnek a versengő ELISA módszerek szelektivitásának, a kimutatási határ azonban két nagyságrenddel kisebb, mint a hasonló biológiai, biokémiai rendszert alkalmazó eljárásé, így egyszerű mintaelőkészítési eljárásokat alkalmazva gyors mérési / monitorozási lehetőséget biztosíthat az OWLS technika. 


\section{SUMMARY}

The aim of my work was to develop immunosensors for food and environmental analytical applications. In the course of this I developed an immunosensor suitable for DON detection, and with the established sensor I determined the DON content of wheat flour samples. After that a sensor suitable for detection of Vtg from carp (Cyprinus carpio) and frog (Bombina bombina) samples were developed, used as a biomarker to detect surface water contamination with EDCs.

In the first steps of the sensor development changes of the OWLS signal were investigated in modelling studies in order to prove that the surface modification and immobilization steps are reproducible. In my experiments I investigated the changes in the thickness of the added layer during the surface modification and immobilization. It has been found out that the thickness of the native waveguide layer is about 170-200 nm, the surface modification with APTS resulted a $0.44 \pm 0.07 \mathrm{~nm}$, the applied $2.5 \%$ glutaraldehyde $0.27 \pm 0.07 \mathrm{~nm}$ changes in the thickness. The dependence of sensor response on analyte molecular mass and concentration was also investigated, where it was concluded that the sensor response is propotional to the molecular mass, and it increased linearly with the increasing concentration of the analyte applied. Sensor response time and accuracy were also investigated by monitoring the variability of the chip's $\mathrm{T}_{\mathrm{M}}$ and $\mathrm{T}_{\mathrm{E}}$ incoupling angles. According to my results the average $\alpha_{\mathrm{TM}}$ and $\alpha_{\mathrm{TE}}$ were $\alpha_{\mathrm{TM}}=0.724627 \pm 0.0000824(0.011 \%$ relative error $), \alpha_{\mathrm{TE}}=3.197883 \pm 0.000157(0.005 \%$ relative error) which enables a very accurate sensing. It could be stated that depending on the conditions set in the protocols, 4-10 detection points could be determined per minutes, which data acquisition speed is suitable for monitoring reactions in real-time.

In my work a competitive immunosensor was developed for deoxynivalenol mycotoxin determination in wheat samples. From the DON mycotoxin, after a pre-treatment with sodiumperiodate conjugates were prepared using OVA and BSA. Polyclonal antibodies were made with the help of the DON-OVA conjugate. Competitive immunosensor was developed by using the biomolecules. Investigating the DON standards by the optimized functional parameters the dynamic range was $0.01-50 \mathrm{ng} / \mathrm{ml}$, the $\mathrm{IC}_{50}$ value was $0.15 \pm 0.08 \mathrm{ng} / \mathrm{ml}\left(\chi^{2}\right.$ degree of freedom $=1.57, \mathrm{r}^{2}=0.99$ ), and the LOD was $0.001 \mathrm{ng} / \mathrm{ml}$. According to the calibration curve obtained with the spiked wheat samples, the dynamic measuring range for the wheat samples was between $0.01-10 \mathrm{mg} / \mathrm{kg}$, the $\mathrm{IC}_{50}$ value was $0.13 \pm 0.04 \mathrm{mg} / \mathrm{kg}$, and the recoveries were over $90 \%$, therefore the sensor fulfils the requirements for the maximum levels according to the EU regulation to detect DON from wheat. (The European Comission regulated the max. level for $1750 \mu \mathrm{g} / \mathrm{kg}$ in unprocessed durum wheat flour, corn and oat (EC reg. No. 1881/2006).) 
Competitive immunosensor was developed with OWLS detection for determination of fish (carp, Cyprinus Carpio) and frog (fïrebellied toad, Bombina bombina) derived vitellogenin. For the investigation Lpv protein was applied, which is easier to isolate and gives $95 \%$ cross-reactivity with the Vtg from the same species. Purification of Lpv was performed from the ovary of carp and oriental fire bellied toad (Bombina orientalis). Antibodies were produced in rabbits immunised with purified Lpv proteins. Immunosensors were established using the purified Lpv proteins and the produced antibodies. For the investigation of carp Vtg competitive measuring method was applied, where the sensor surface was sensitized with $5 \mu \mathrm{g} / \mathrm{ml} \mathrm{Lpv}$ solution and for the measurement polyclonal antibody was applied at concentration of $64.1 \mu \mathrm{g} / \mathrm{ml}$. After optimization of the operational parameters the measurements were carried out by applying $0.08 \mathrm{ml} / \mathrm{min}$ flowrate after 3 minutes incubation at $20{ }^{\circ} \mathrm{C}$. Analysing the carp-Lpv the calibration curve's dynamic measuring range was between $3-150 \mathrm{ng} / \mathrm{ml}$, the $\mathrm{IC}_{50}$ value was $21.18 \pm 2.86 \mathrm{ng} / \mathrm{ml}$ and the LOD was $0.7 \mathrm{ng} / \mathrm{ml}$. Vitellogenin content was determined in blood from male and female carp raised under ecological conditions, and I also investigated the recovery ratio of the spiked Lpv content. According to my results, Vtg levels in blood from male carps were found to be $0.5 \pm 0.3,5.0 \pm 1.8$ and $6.2 \pm 0.8 \mu \mathrm{g} / \mathrm{ml}$, while from female carps $246.1 \pm 19.6,367.5 \pm 54.7,465.4 \pm 46.9 \mathrm{Vtg}$ proteins were detected by the immunosensor. Concentration of Vtg was also measured in liver samples from carp. According to my findings the matrix effects of the samples were substantially bigger than those in the blood serum. In the liver tissues of male carp $1.1 \pm 0.7,1.8 \pm 1.1$ and $2.6 \pm 0.9$ $\mu \mathrm{g} / \mathrm{ml} \mathrm{Vtg}$ were measured, while those from female animals we measured to contain $28.6 \pm 6.3$, $29.7 \pm 5.4$ and $40.9 \pm 4.7 \mu \mathrm{g} / \mathrm{ml} \mathrm{Vtg}$. The recovery ratio was $140 \%, 89 \%, 84 \%$ from the blood samples with 1, 10, $100 \mathrm{ng} / \mathrm{ml} \mathrm{Lpv} \mathrm{protein} \mathrm{content,} \mathrm{respectively.} \mathrm{Results} \mathrm{indicate} \mathrm{that} \mathrm{the}$ developed immunosensor is suitable for determination of Vtg in the blood of male carp.

$100 \mathrm{ng} / \mathrm{ml}$ carp Lpv was immobilised by EDC/NHS method on the surface of the sensor containing carboxyl groups for the development of the competitive immunosensor suitable for Vtg determination in frog. The polyclonal antibody was applied at dilution of $2.22 \mu \mathrm{g} / \mathrm{ml}$. The dynamic measuring range was between $0.5-10 \mathrm{ng} / \mathrm{ml}$ for the frog Lpv. The LOD was $0,1 \mathrm{ng} / \mathrm{ml}$, while the $\mathrm{IC}_{50}$ value was $1.04 \pm 0.14 \mathrm{ng} / \mathrm{ml}$. Vitellogenin content was investigated in liver, heart, blood and gonad tissue samples from male and female toads. Among the samples the highest concentration was found in the ovarium and ovum $(754 \pm 73.5$ and $1030.0 \pm 298.5 \mu \mathrm{g} / \mathrm{g})$.

According to my results it can be stated that the developed immunosensor method is suitable for fish (carp, Cyprinus carpio) and frog (fire bellied toad, Bombina bombina) Vtg protein determination. On the basis of the Vtg level measured in male individuals, the contamination of the freshwater and aqueous habitat with endocrine disruptors could be monitored. 
In the course of investigation my main goal was sensor development. It could be concluded, that the selectivity of the developed immonosensors was similar as compared to that of the competitive ELISA, but the LOD was a two orders of magnitude lower than that detected by similar biological, biochemical methods, thus the OWLS technique could offer a rapid measuring / monitoring method by using simple sample preparation. 


\section{IRODALOMJEGYZÉK}

ACTIS, P., JEJELOWO, O.A., POURMAND, N. (2010) Ultrasensitive mycotoxin detection by STING sensors. Biosensor and Bioelectronics 26, 333-337.p. DOI: $\underline{10.1016 / \mathrm{j} . b i o s .2010 .08 .016}$

ADÁNYI, N. (2014) Immun- és bakteriális szenzorok fejlesztése optikai hullámvezető fénymódus spektroszkópiai detektálással, és alkalmazásuk az élelmiszerbiztonság valamint a környezetvédelem területén. MTA doktori értekezés URI: http://real-d.mtak.hu/id/eprint/674

ADÁNYI, N., LEVKOVETS, I.A., RODRIGUEZ, G.S., RONALD, A., VÁRADI, M., SZENDRÖ, I. (2007) Development of immunosensor based on owls technique for determining aflatoxin B1 and ochratoxin A. Biosensor and Bioelectronics. 22 (6) 797-802.p.

ALBERT, A.L., CHAMPOUX, P.D., DAVIS, A.H. (2013) QuickTox ${ }^{\mathrm{TM}}$ Kit for QuickScan DON (Vomitoxin). Journal of AOAC International 96 (5) 1006-1016.p. DOI: 10.5740/jaoacint.12-472

AMARAL-MENDES, J.J. (2002) The endocrine disrupters: a major medical challenge. Food and Chemical Toxicology 40, 781-788.p. DOI: 10.1016/S0278-6915(02)00018-2

AN, L., HU, J., ZHANG, Z., YANG, M. (2006) Quantitative real-time RT-PCR for determination of vitellogenin mRNA in so-iuy mullet (Mugil soiuy). Analiytical and Bioanalytical Chemistry 386 (7-8) 1995-2001.p. DOI: 10.1007/s00216-006-0846-y

APSIMON, J.W., BLACKWELL, B.A., BLAIS, L., FIELDER, D.A., GREENHALGH, R., KASITU, G., MILlER, J.D., SAVARD, M. (1990): Mycotoxins from Fusarium species: detection, determination and variety. Pure Applied Chemistry 62, 339-346.p. DOI: $\underline{10.1351 / \mathrm{pac} 199062071339}$

ARCAND-HOY, L., BENSON, W.H. (1998) Fish reproduction: an ecologically relevant indicator of endocrine disruption. Environmental Toxicology and Chemistry 17 (1) 49-57.p. DOI: $\underline{10.1002 / \text { etc. } 5620170108}$

BADEA, M., MICHELI, L., MESSIA, M.C, CANDIGLIOTA, T., MARCONI, E., MOTTRAM, T., VELASCO-GARCIA, M., MOSCONE, D., PALlESCHI, G. (2004): Aflatoxin M1 determination in raw milk using a flow injection immunoassay system. Analytica Chimica Acta, 520, 141 - 148.p. DOI: $\underline{10.1016 / j . a c a .2004 .05 .068}$

BANGE, A., HALSALL, H.B., HEINEMAN, W.R. (2005): Microfluidic immunosensor systems. Biosensors and Bioelectronics 20, 2488-2503.p. DOI: 10.1016/j.bios.2004.10.016 
BARUCCA, M., CANAPA, A., OLMO, E., REGOLI, F. (2006) Analysis of vitellogenin gene induction as a valuable biomarker of estrogenic exposure in various Mediterranean fish species. Environmental Research 101, 68-73.p. DOI: 10.1016/j.envres.2005.07.002

BARZEN, C., BRECHT, A., GAUGLITZ, G. (2002) Optical multiple-analyte immunosensor for water pollution control. Biosensors and Bioelectronics 17 (4) 289 - 295.p. DOI: 10.1016/S0956$\underline{5663(01) 00297-4}$

BERTHILLER, F., DALL'ASTA, C., SCHUHMACHER, R., LEMMENS, M., ADAM, G., KRSKA, R. (2005) Masked mycotoxins: determination of a deoxynivalenol glucoside in artificially and naturally contaminated wheat by liquid chromatography-tandem mass spectrometry. Journal of Agricultural and Food Chemistry 53 (9) DOI: 3421-3425.p. $10.1021 / \mathrm{jf047798g}$

BIER, F.F., SCHMID, R.D. (1994) Real time analysis of competitive binding using grating coupler immunosensors for pesticide detection. Biosensors and Bioelectronics 9, 125-130.p.

BOROS, T. (2004) Endokrin hatású anyagok a szennyvíztisztítókban. Müszaki információ: Környezetvédelem, 1-2., 74-81 p.

BÖHM, C., CICHNA-MARKL, M., BRENN-STRUCKHOFOVA, Z., RAZZAZI-FAZELI, E. (2008) Development of a selective sample clean-up method based on immunoultrafiltration for the determination of deoxynivalenol in maize. Journal of Chromatography A 1202, 111-117.p. DOI: $\underline{10.1016 / j . c h r o m a .2008 .06 .021}$

BRADFORD, M.M. (1986) A rapid and sensitive method for the quanti tation of microgram quantities of protein utilizing the principle of protein-dye binding. Analytical Biochemistry 72, 248-254.p. DOI: 10.1016/0003-2697(76)90527-3

BRION, F., NILSEN, B.M., EIDEM, J.K., GOKSOYR, A., PORCHER, J.M. (2002) Development and validation of an enzyme-linked immunosorbent assay to measure vitellogenin in the zebrafish (Danio rerio). Environmental Toxicology and Chemistry 28, 1699-1708.p. DOI: 10.1002/etc.5620210823

BRULS, D.M., EVERS, T.H., KAHLMAN, J.A.H., VAN LANKVELT, P.J.W., OVSYANKO, M., PELSSERS, E.G.M., SCHLEIPEN, J.J.H.B., DE THEIJE, F.K., VERSCHUREN, C.A., VAN DER WIJK, T., VAN ZON, J.B.A., DITTMER, W.U., IMMINK, A.H.J., NIEUWENHUISA, J.H., PRINS, M.W.J. (2009) Rapid integrated biosensor for multiplexed immunoassays based on actuated magnetic nanoparticles. Lab on a Chip 9 3504-3510.p. DOI: 10.1039/B913960E 
BUluKin, E., MEUCCI, V., MINUNNI, M., PRETTI, C., INTORRE, L., SOLDANI, G., MASCINI, M. (2007) An optical immunosensor for rapid vitellogenin detection in plasma from carp (Cyprinus carpio). Talanta 72, 785-790.p. DOI: 10.1016/j.talanta.2006.12.007

CAMPAGNOLI, A., CHELI, F., POLIDORI, C., ZANINELLI, M., ZECCA, O., SAVOINI, G., PINOTTI, L., DELL'ORTO, V. (2011) Use of the Electronic Nose as a Screening Tool for the Recognition of Durum Wheat Naturally Contaminated by Deoxynivalenol: A Preliminary Approach. Sensors 11, 4899-4916.p. DOI: $10.3390 /$ s110504899

CAMPBELL, G.A., MEDINA, M.B., MUTHARASAN, R. (2007) Detection of Staphylococcus enterotoxin B at picogram levels using piezoelectric-excited millimeter-sized cantilever sensors. Sensors and Actuators B: Chemical 126 (2) 354-360.p. DOI: 10.1016/j.snb.2007.03.021

CANADY, R.A, COKER, R.D., EGAN, S.K., KRSKA, R., KUIPER-GOODMAN, T., OLSEN, M., PESTKA, J., RESNIK, S., SCHLATTER, J. (2001) Evaluation of certain mycotoxins in food. WHO Food Additives Series No. 47/FAO Food and Nutrition Paper 74

CHOI, S.W., CHANG, H.J., LEE, N., CHUN, H.S. (2011) A Surface Plasmon Resonance Sensor for the Detection of Deoxynivalenol Using a Molecularly Imprinted Polymer. Sensors 11 (9) 86548664.p. DOI: $\underline{10.3390 / \mathrm{s} 110908654}$

CLERC, D., LUKOSZ, W. (1997) Direct immunosensing with an integrated-optical output grating coupler. Sensors and Actuators B:Chemical 40, 53-58.p. DOI: 10.1016/S0925-4005(97)80199-2

COHEN, A.M., MANSOUR, A.A., BANOUB, J.H. (2006) Absolute quantification of Atlantic salmon and rainbow trout vitellogenin by the 'signature peptide' approach using electrospray ionization QqToF tandem mass spectrometry. Journal of Mass Spectrometry 41 (5) 646-658.p. DOI: $10.1002 / j m s .1023$

COMMISSION REGULATION (EC) (2006) No 1881/2006 of 19 December Setting maximum levels for certain contaminants in foodstuffs. Official Journal of the European Union L364/5

CRAS, J.J., ROWEE-TAITT, C.A., NIVENS, D.A., LIGLER, F.S. (1999) Comparison of chemical cleaning methods of glass in preparation for silanization. Biosensors and Bioelectronics 14, 683-688.p. DOI: 10.1016/S0956-5663(99)00043-3

CUNHA, S.C., FERNANDES, J.O. (2010) Development and validation of a method based on a QuEChERS procedure and heart-cutting GCeMS for determination of five mycotoxins in cereal products. Journal of Separation Science 33 (4-5) 600-609.p. DOI: 10.1002/jssc.200900695. 
DARAIN, F., PARK, D.S., PARK, J.S., CHANG, S.C., SHIM, Y.B. (2005) A separation-free amperometric immunosensor for vitellogenin based on screen-printed carbon arrays modified with a conductive polymer. Biosensors and Bioelectronics 20, 1780-1787.p. DOI: 10.1016/j.bios.2004.07.006

DARAIN, F., PARK, D.S., PARK, J.S., SHIM, Y.B. (2004) Development of an immunosensor for the detection of vitellogenin using impedance spectroscopy. Biosensors and Bioelectronics 19, 1245-1252.p. DOI: 10.1016/j.bios.2003.11.014

DE FEIJTER, J.A., BENJAMINS, J., VEER, F.A. (1978) Ellipsometry as a tool to study the adsorption of synthetic and biopolymers at the air-water Interface. Biopolymers 17, 1759-1773.p. DOI: 10.1002/bip.1978.360170711

DOS SANTOS, J.S., TAKABAYASHI, C.R., ONO, E.Y., ITANO, E.N., MALLMANN, C.A., KAWAMURA, O., HIROOKA, E.Y. (2011) Immunoassay based on monoclonal antibodies versus LC-MS: deoxynivalenol in wheat and flour in Southern Brazil. Food Additives and Contaminants 28 (8) 1083-90.p. DOI: 10.1080/19440049.2011.576442

EFSA (European Food Safety Authority) (2013) Deoxynivalenol in food and feed: occurrence and exposure. EFSA journal 11 (10) 3379.p.

ENGSTRÖM, H.A., ANDERSSON, P.O., OHLSON, S. (2006) A label-free continuous totalinternal-reflection-fluorescence-based immunosensor. Analytical Biochemistry 357 (2) 159-166.p. DOI: $\underline{10.1016 / \text { j.ab.2006.03.058 }}$

FUKADA, H., FUJIWARA, Y., TAKAHASHI, T., HIRAMATSU, N., SULLIVAN, C.V., HARA, A. (2003) Carp (Cyprinus carpio) vitellogenin: purification and development of a simultaneous chemiluminescent immunoassay. Comparative Biochemistry and Physiology Part A 134, 615-623.p. DOI: 10.1016/S1095-6433(02)00348-3

GARIPCAN, B., CAGLAYAN, M., DEMIREL, G. (2011) New generation biosensors based on ellypsometry, new perspectives in biosensors technology and applications, Prof. Pier Andrea Serra (Ed.). InTech ISBN: 978-953-307-448-1, DOI: 10.5772/16256.

GYURCSÁNYI, E.R. (2005) Új irányok a biomolekuláris felismerés detektálásában. Magyar Kémiai Folyóírat 111 (3) 133-141.p.

HAJÓS, GY., IDEI, M. (2001) Elektroforetikus és elektrokromatográfiás módszerek fejlődése és alkalmazási lehetőségei I. Magyar Kémikusok Lapja 56 (10) 364-368.p. 
HARA, A., HIRANO, K., SHIMIZU, M., FUKADA, H., FUJITA, T., ITO, F., TAKADA, H., NAKAMURA, M., IGUCHI, T. (2007) Carp (Cyprinus carpio) vitellogenin characterization of yolk proteins, development of immunoassays and use as biomarker of exposure to environmental estrogens. Environmental Science and Technology 14 (2) 95-108.p.

HARBOE, N., INGLID, A. (1973) Immunization, isolation of immunoglobulin, estimation of antibody titer. Scandinavian Journal of Immunology Suppl. 1., 161-169.p. DOI: 10.1111/j.13653083.1973.tb03798.x

HEGEDÜS, GY., BÉLAI, I., SZÉKÁCS, A. (2000) Development of an enzyme-linked immunosorbent assay (ELISA) for the herbicide trifluralin. Analytical Chimica Acta 421, 121133.p. DOI: $\underline{10.1016 / \mathrm{S} 0003-2670(00) 01045-\mathrm{X}}$

HEGYI, GY. et al. (2013): Bevezetés a biokémiába gyakorlati jegyzet. ELTE-TTK. 195.p.

HEIDEMAN, R.G., KOOYMAN, R.P.H., GREVE, J., (1993) Performance of a highly sensitive optical waveguide Mach-Zehnder interferometer immunosensor. Sensors and Actuators B: Chemical 10 209-217.p. DOI: 10.1016/0925-4005(93)87008-D

HOLBECH, H., ANDERSEN, L., PETERSEN, G.I., KORSGAARD, B., PEDERSEN, K.L., BJERREGAARD, P. (2001) Development of an ELISA for vitellogenin in whole body homogenate of zebrafish (Danio rerio). Comparative Biochemistry and Physiology C 130 (1) 119131.p. DOI: $\underline{10.1016 / \mathrm{S} 1532-0456(01) 00229-0}$

HUNT, H.K., SOTEROPUlOS, C., ARMANI, A.M. (2010) Bioconjugation Strategies for Microtoroidal Optical Resonators. Sensors 10, 9317-9336.p. DOI: $\underline{10.3390 / \text { s101009317 }}$

HUTCHINSON, T.H., ANKLEY G.T., SEGNER, H., TYLER, C.R. (2006) Screening and Testing for Endocrine Disruption in Fish- Biomarkers as „Signposts” not „Traffic Lights” in Risk Assessment. Environmental Health Perspectives 114, 106-114.p. DOI: 10.1289/ehp.8062

IBÁÑEZ-VEA， M., LIZARRAGA， E.，GONZÁLES-PEÑAS， E. (2011) Simultaneous determination of type-A and type-B trichothecenes in barley samples by GC-MS. Food Control 22 (8) 1428-1434.p. DOI: 10.1016/j.foodcont.2011.03.004

JAKOVAC-STRAJN, B., TAVČAR-KALCHER, G. (2012) A Method Using Gas Chromatography-Mass Spectrometry for the Detection of Mycotoxins from Trichothecene Groups A and B in Grains. In Salih, B., Çelikbıçak, Ö. : Gas Chromatography in Plant Science, Wine Technology, Toxicology and Some Specific Applications. InTech 225-244.p. DOI: 10.5772/31788 
JI, F., LI, H., XU, J., SHI, J. (2011) Enzyme-Linked Immunosorbent-Assay for Deoxynivalenol (DON). Toxins 3 (8) 968-978.p. DOI: 10.3390/toxins3080968

JIMENEZ M., MATEO, R. (1997) Determination of mycotoxins produced by Fusarium isolates from banana friuts by capillary gas chromatography and high-performance liquid chromatography. Journal of Chromatography A 778, 363-372.p. DOI: 10.1016/S0021-9673(97)00328-2

KADOTA, T., TAKEZAWA, Y., HIRANO, S., TAJIMA, O., MARAGOS, C.M., NAKAJIMA, T., TANAKA, T., KAMATA, Y., SUGITA-KONISHI, Y. (2010) Rapid detection of nivalenol and deoxynivalenol in wheat using surface plasmon resonance immunoassay. Analytica Chimica Acta 673 (2) 173-178.p. DOI: 10.1016/j.aca.2010.05.028

KERA, Y., KATO, T., KOSHIBA, K., YAMADA, R. (2000) Koi carp (Cyprinus carpio) vitellogenin: purification, $\mathrm{N}$-terminal and internal ami-no acid sequences and establishment of an enzyme-linked immunosorbent assay (ELISA). Japanese Journal of Environmental Toxicology 3 , 47-62.p.

KLINGLMAYR, C., NOBAUER, K., RAZZAZI-FAZELI, E., CICHNA-MARKL, M. (2009) Determination of deoxynivalenol in organic and conventional food and feed by sol-gel immunoaffinity chromatography and HPLC-UV detection. Journal of Chromatography B, Analytical Technologies in the Biomedical and Life Sciences 878 (2) 187-193.p. DOI: 10.1016/j.jchromb.2009.08.016

KOlOSOVA, A.Y., SIBANDA, L., DUMOUlin, F., LEWIS, J., DUVEILlER, E., VAN PETEGHEM, C., DE SAEGER, S. (2008) Lateral-flow colloidal gold-based immunoassay for the rapid detection of deoxynivalenol with two indicator ranges. Analytica Chimica Acta 616 (2) 235 244.p. DOI: 10.1016/j.aca.2008.04.029

KRSKA, R., WELZIG, E., BERTHILlER, F., MOLINELlI, A., MIZAIKOFF, B. (2005) Advances in the analysis of mycotoxins and its quality assurance. Food Additives and Contaminants 22 (4) 345-353.p. DOI: 10.1080/02652030500070192

LANGSETH, W., RUNDBERGET, T. (1998) Instrumental methods for determination of nonmacrocyclic trichothecenes in cereals, foodstuff and cultures. Journal of Chromatography A 815, 103-121.p. DOI: 10.1016/S0021-9673(98)00388-4 
LATTANZIO, V.M.Z., SOLFRIZZO, M., POWERS, S.,VISCONTI, A. (2007) Simultaneous determination of aflatoxins, ochratoxin A and Fusarium toxins in maize by liquid chromatography/tandem mass spectrometry after multitoxin immunoaffinity cleanup. Mass Spectrometry 21 (20) 3253-3261.p. DOI: 10.1002/rcm.3210

LECA-BOUVIER, B., BLUM, L.J. (2005): Biosensors for protein detection: a review. Analytical Letters 38 (10) 1491-1517.p. DOI: 10.1081/AL-200065780

LECHUGA, L.M., LENFERINK, A.T.M., KOOYMAN, R.P.H., GREVE, J. (1995) Feasibility of evanescent wave interferometer immunosensors for pesticide detection: chemical aspects. Sensors \& Actuators: B. Chemical 25 (1-3) 762-765.p. DOI: 10.1016/0925-4005(95)85169-0

LEVKOVETS, I., ADÁNYI, N., TRUMMER, N., VÁRADI, M., SZENDRÖ, I., STARODUB, N.F., SZÉKÁCS, A. (2004) Development of optical (OWLS) immunosensors for macromolecules. Biokémia XXVIII, 7-15.p.

LI, C.R., JUNG K.S., LEE, S.H., KIM, A., PARK, J.S. (2006) Development of a sandwich enzyme-linked immunosorbant assay for the quantification of vitellogeinin in Bullfrog (Rana catesbeiana) Chemosphere 63 (9) 1485-1490.p. DOI: 10.1016/j.chemosphere.2005.09.041

LI, D., WANG, J., WANG, R., LI L., ABI-GHANEM, D., BERGHMAN, L., HARGIS, B., LU, H. (2011) A nanobeads amplified QCM immunosensor for the detection of avian influenza virus H5N1. Biosensors and Bioelectronics 26 (10) 4146-4154.p. DOI: 10.1016/j.bios.2011.04.010.

LIAO, T., JIN, S., YANG, F.X., HUI, Y., XU, Y. (2006) An enzyme-linked immunosorbent assay for rare minnow (Gobiocypris rarus) vitellogenin and comparison of vitellogenin responses in rare minnow and zebrafish (Danio rerio). Science of the Total Environment 364 (1-3) 284-294.p. DOI: 10.1016/j.scitotenv.2006.02.028

LIEDBERG, B., NYLANDER, C., LUNDSTROM, I. (1983) Surface plasmon resonance for gas detection and biosensing. Sensors and Actuators 4, 299-304.p. DOI: 10.1016/0250$\underline{6874(83) 85036-7}$

LIEDBERG, B., NYLANDER, C., LUNDSTROM, I. (1995) Biosensing with surface plasmon resonance - how it all started. Biosensors and Bioelectronics 10 (8) i-ix.p. DOI: 10.1016/09565663(95)96965-2 
LIPPOLIS, V., PASCALE, M., VISCONTI, A. (2006) Optimization of a fluorescence polarization immunoassay for rapid quantification of deoxynivalenol in Durum wheat-based products. Journal of Food Protection 11, 2712-2719.p.

LIU, J., ZANARDI, S., POWERS, S., SUMAN, M. (2012) Development and practical application in the cereal food industry of a rapid and quantitative lateral flow immunoassay for deoxynivalenol. Food Control 26 (1) 88-91.p. DOI: 10.1016/j.foodcont.2012.01.005

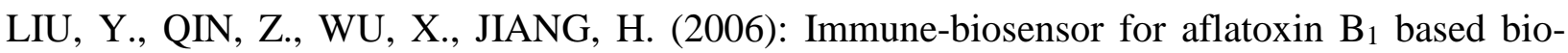
electrocatalytic reaction on micro-comb electrode. Biochemical Engineering Journal, 32, 211-217. p. DOI: $\underline{10.1016 / j . b e j .2006 .10 .003}$

MAK, A.C., OSTERFELD, S.J., YU H., WANG, S.H., DAVIS, R.W., JEJELOWO, O.A., POURMAND, N. (2010) Sensitive giant magnetoresistive-based immunoassay for multiplex mycotoxin detection. Biosensor and Bioelectronics 25, 1635-1639.p. DOI: 10.1016/j.bios.2009.11.028

MALLAT, E., BARZEN, C., ABUKNESHA, R., GAUGLITZ, G., BARCELÓ, D. (2001) Part per trillion level determination of isoproturon in certified and estuarine water samples with a direct optical immunosensor Analytica Chimica Acta 426 (2) 209-216.p. DOI: 10.1016/S0003$\underline{2670(00) 00841-2}$

MARAGOS, C.M. (2011) Detection of deoxynivalenol using biolayer interferometry. Mycotoxin Research 27 (3) 157-65.p. DOI: 10.1007/s12550-011-0090-y

MARAGOS, C.M. (2012) Signal amplification using colloidal gold in a biolayer interferometrybased immunosensor for the mycotoxin deoxynivalenol. Food Additives and Contaminants Part A 29 (7) 1108-17.p. DOI: 10.1080/19440049.2012.671

MARAGOS, C.M., BUSMAN, M., SUGITA-KONISHI, Y. (2006) Production and characterization of a monoclonal antibody cross-reactive with the mycotoxins nivalenol and 4deoxynivalenol. Food Additives and Contaminants 23 (8) 816-825.p. DOI: $10.1080 / 02652030600699072$

MARAGOS, C.M., PLATTNER, R.D. (2002) Rapid fluorescence polarization immunoassay for the mycotoxin deoxynivalenol in wheat. Journal of Agriultural and Food Chemistry 50, 18271832.p. DOI: 10.1021/jf011487d 
MARAGOS, C.M., THOMPSON, V.S. (1999) Fiber-optic immunosensor for mycotoxins. Natural Toxins 7 (6) 371-376.p. DOI: 10.1002/1522-7189(199911/12)7:6<371::AID-NT86>3.0.CO;2-8

MENDES, J.J.A (2002) The endocrine disrupters: a major medical challenge. Food and Chemical Toxicology 40, 781-788.p. DOI: 10.1016/S0278-6915(02)00018-2

MENEELY, J., FODEY, T., ARMSTRONG, L., SULYOK, M., KRSKA, R., ELLIOT, C. (2010) Rapid surface plasmon resonance immunoassay for the determination of deoxynivalenol in wheat, wheat products, and maize-based baby food. Journal of Agricultural and Food Chemistry 58 (16) 8936-41.p. DOI: 10.1021/jf101517s

MICHELI, L., GRECCO, R., BADEA, M., MOSCONE, D., PALlESCHI, G. (2005): An electrochemical immunosensor for aflatoxin $\mathrm{M}_{1}$ determination in milk using screen-printed electrodes. Biosensors and Bioelectronics, 21 (4) 588-96. p. DOI: 10.1016/j.bios.2004.12.017

MULLETT, W., LAI, E.P., YEUNG, J.M. (1998) Immunoassay of fumonisins by a surface plasmon resonance biosensor. Analytical Biochemistry 258 (2) 161-167.p. DOI: $\underline{10.1006 / a b i o .1998 .2616}$

MUSCARELLA, M., IAMMARINO, M., NARDIELLO, D., PALERMO, C., CENTONZE, D. (2012) Determination of deoxynivalenol and nivalenol by liquid chromatography and fluorimetric detection with on-line chemical post-column derivatization. Talanta 97, 145-149.p. DOI: 10.1016/j.talanta.2012.04.009

NABOK, A.V., MUSTAFA, M.K., TSARGORODSKAYA, A., STARODUB, N.F. (2011) Detection of aflatoxin B1 with a label-free ellipsometry immunosensor. BioNanoScience, 1 (1-2) 38-45.p. DOI: $\underline{10.1007 / \mathrm{s} 12668-011-0006-5}$

NABOK, A.V., TSARGORODSKAYA, A., HASSAN, A.K., STARODUB, N.F. (2005) Total internal reflection ellipsometry and SPR detection of low molecular weight environmental toxins. Applied Surface Science, 246 (4) 381-386.p. DOI: 10.1016/j.apsusc.2004.11.084

NABOK, A.V., TSARGORODSKAYA, A., HOLlOWAY, A., STARODUB, N.F., GOJSTER, O. (2007) Registration of T-2 mycotoxin with total internal reflection ellipsometry and QCM impedance methods. Biochemical and Biomolecular Sensing, 22 (6) 885-890.p. DOI: $\underline{10.1016 / j . b i o s .2006 .03 .010}$

NAKAMURA, M., IGUCHI T. (1998) Abnormal fish in Tagawa river. Journal of the Japanese Society for Food Science and Technology-nippon Shokuin Kagaku Kogaku Kaishi 68, 534-517.p. 
OLSSON,J., BÖRJESSON, T., LUNDSTEDT, T., SCHNÜRER, J. (2002) Detection and quantification of ochratoxin A and deoxynivalenol in barley grains by GC-MS and electronic nose. International Journal of Food Microbiology 72 (3) 203-214.p. DOI: 10.1016/S0168$\underline{1605(01) 00685-7}$

ONJI, Y., AOKI, Y., TANI, N., UMEBAYASHI, K., KIDATA, Y., DOHI, Y. (1998) Direct analysis of several Fusarium mycotoxins in cereals by capillary gas chromatography mass spectrometry. Journal of Chromatography A 815, 59-65.p. DOI: 10.1016/S0021-9673(98)00357$\underline{4}$

OSBORNE, L.E, STEIN, J.M. (2007) Epidemiology of Fusarium head blight on small-grain cereals. International Journal of Food Microbiology 119 (1-2) 103-108.p. DOI: 10.1016/j.ijfoodmicro.2007.07.032

PARKS, L.G., CHEEK, A.O., DENSLOW, N.D., HEPPELL, S.A., MCLACHLAN, J.A., LEBLANC, G.A., SULliVAN, C.V. (1999) Fathead minnow (Pimephales promelas) vitellogenin: purification, characterization and quantitative immunoassay for the detection of estrogenic compounds. Comparative Biochemistry and Physiology 123, 113-125.p.

PATEL, P.D. (2002): (Bio)sensors for measurement of analytes implicated in food safety: a review. Trends in Analytical Chemistry 21, 96-115.p. DOI: 10.1016/S0165-9936(01)00136-4

PERKOWSKI, J., JELEN, H., KIECANA, I., GOLINSKI, P. (1997) Natural contamination of sprig barley with group A trichotecene mycotoxins in southeastern Poland. Food Additives and Contaminants 14, 321-325.p. DOI: 10.1080/02652039709374533

PESTKA J.J. (2010) Deoxynivalenol: mechanisms of action, human exposure, and toxicological relevance. Archive of Toxicology 84 (9) 663-679.p. DOI: 10.1007/s00204-010-0579-8

PIETRO-SIMÓN, B., NOGUER, T., CAMPAS, M. (2007) Emerging biotools for assessment of mycotoxins in the past decade. Trends in Analytical Chemistry 26 (7) 689-702.p. DOI: 10.1016/j.trac.2007.05.012

PLACINTA, C.M., MELLO, J.P.F., MACDONALD, A.M.C. (1999) A review of worldwide contamination of cereal grains and animal feed with Fusarium mycotoxins. Animal Feed Science and Technology 78, 21-37.p. DOI: $\underline{10.1016 / \mathrm{S} 0377-8401(98) 00278-8}$

POKOL, GY. (Szerk.) (2011) Analitikai kémia. Typotex Kiadó. 410 p. 
PRÖLL, F., MOEHRLE, B., KUMPF, M., GAUGLITZ, G. (2005): Label-free characterization of oligonucleotide hybridization using reflectometric interference spectroscopy. Analytical and Bioanalytical Chemistry 382 (8) 1889-1894.p. DOI: 10.1007/s00216-005-3301-6

PURDOM, C.E., HARDIMAN, P.A., BYE, V.J., ENO, N.C., TYLER,C.R., SUMPTER, J.P. (1994) Estrogenic effects of effluents from sewage treatment works. Chemistry and Ecology 8, 275-285.p. DOI: 10.1080/02757549408038554

RAHMANI, A., JINAP, S., SOLEIMANY, F (2009) Qualitative and Quantitative Analysis of Mycotoxins. Comprehensive Reviews in Food Science and Food Safety 8 (3) 202-251.p. DOI: 10.1111/j.1541-4337.2009.00079.x

RAN, R., WANG, C., HAN, Z., WU, A., ZHANG, D., SHI, J. (2013) Determination of deoxynivalenol (DON) and its derivatives: Current status of analytical methods. Food Control 34 (1) 138-148.p. DOI: 10.1016/j.foodcont.2013.04.026

RICCIARDI, C., CASTAGNA, R., FERRANTE, I., FRASCELLA, F., MARASSO, S.L., RICCI, A., CANAVESE, G., LORÈ, A., PRElle, A., GUllinO, M.L., SPADARO, D. (2013) Development of a microcantilever-based immunosensing method for mycotoxin detection. Biosensors and Bioelectronics 40 (1) 233-239.p. DOI: 10.1016/j.bios.2012.07.029

RODRIGUEZ-MOZAZ, S., REDER, S., DE ALDA, M.L, GAUGLITZ, G., BARCELÓ, D.(2004) Simultaneous multi-analyte determination of estrone, isoproturon and atrazine in natural waters by the RIver ANAlyser (RIANA), an optical immunosensor. Biosensors and Bioelectronics 19 (7) 633-640.p. DOI: $\underline{10.1016 / \text { S0956-5663(03)00255-0 }}$

ROTTER, B.A., PRELUSKY, D.B., PESTKA, J.J. (1996) Toxicology of deoxynivalenol (vomitoxin). Journal of Toxicology and Environmental Health 48 (1) 1-34.p. DOI: $10.1080 / 009841096161447$

RUAN, C., YANG, L., LI, Y. (2002): Immunobiosensor chips for detection of Escherichia coil O157:H7 using electrochemical impedance spectroscopy. Analytical Chemistry 74 (18) 4814-20.p. DOI: $10.1021 / \mathrm{ac} 025647 \mathrm{~b}$

SAUERBREY, G.Z. (1959) The use of quartz oscillators for weighing thin layers and for microweighing. Zeitschrift für Physik 155, 206-222.p. 
SCHIPPER, E.F., BRUGMAN, A.M., LECHUGA, L.M., KOOYMAN, R.P.H., GREVE, J., DOMINGUEZ, C. (1997) The realization of an integrated Mach-Zehnder waveguide immunosensor in silicon technology. Sensors and Actuators B: Chemical 40 147-153.p. DOI: $\underline{10.1016 / \mathrm{S} 0925-4005(97) 80254-7}$

SCHMITT, H.-M., BRECHT, A.,PIEHLER, J., GAUGLITZ, G. (1997): An integrated system for optical biomolecular interaction analysis. Biosensors and Bioelectronics 12 (8) 809-816.p. DOI: $\underline{10.1016 / \mathrm{S} 0956-5663(97) 00046-8}$

SCHOBEL, U., BARZEN, C., GAUGLITZ, G. (2000) Immunoanalytical techniques for pesticide monitoring based on fluorescence detection. Fresenius' Journal of Analytical Chemistry 366 (6-7) 0646 - 0658.p. DOI: 10.1007/s002160051559

SCOTT, P.M. (1989) The natural occurence of trichotecenes. Beasley, V.R. (ed): Trichotecene mycotoxicosis: Pathophysiologic effects. CRC Press Inc. Boca Raton 1, 1-26.p.

SCOTT, P.M., KANHERE, S.R., TARTER, E.J. (1986) Determination of nivalenol and deoxynivalenol in cereals by electron capture gas chromatography. Journal of Association of Offical Analytical Chemists 69, 889.p.

SENYUVA, H.Z., GILBERT, J. (2010) Immunaffinity column clean-up techniques in food analysis: A review. Journal of Chromatography B 878 (2) 115-132.p. DOI: 10.1016/j.jchromb.2009.05.042

SEPÚlVEDA, B., SÁNCHEZ DEL RIO, J., MORENO, M., BLANCO, F.J., MAYORA, K., DOMINGUEZ, C., LECHUGA, L.M. (2006) Optical biosensor microsystems based on the integration of highly sensitive Mach-Zehnder interferometer devices. Journal of Optics A: Pure and Applied Optics 8 (7) 561-566.p. DOI: 10.1088/1464-4258/8/7/S41

SIFUENTES-ROMERO, I., VAZQUEZ-BOUCARD， C., SIERRA-BELTRAN, A.P., GARDNER, S.C. (2006) Vitellogenin in black turtle (Chelonia mydas agassizii): Purification, partial characterization, and validation of an enzyme-linked immunosorbent assay for its detection. Environmental Toxicology and Chemistry 25 (2) 477-485.p. DOI: 10.1897/05-063R2.1

SOBROVA, P., ADAM, V., VASATKOVA, A., BEKLOVA, M., ZEMAN, L., KIZEK, R. (2010) Deoxynivalenol and its toxicity. Interdisciplinary Toxicology; 3 (3) 94-99.p. DOI: 10.2478/v10102-010-0019-x, 
SOH, N., NISHIYAMA, H., MISHIMA, K., IMATO, T., MASADOME, T., ASANO, Y., KUROKAWA, Y., TABEI, H. (2002) Spectrophotometric determination of carp vitellogenin using a sequential injection analysis technique equipped with a jet ring cell. Talanta 58, 11231130.p. DOI: 10.1016/S0039-9140(02)00437-X

SOLEIMANY, F., JINAP, S., ABAS, F. (2012) Determination of mycotoxins in cereals by liquid chromatography tandem mass spectrometry. Food Chemistry 130 (4) 1055-1060.p. DOI: $\underline{\text { 10.1016/j.foodchem.2011.07.131 }}$

SPINKE, J., ORANTH, N., FATTINGER, CH., KOLLER, H., MANGOLD, C., VOEGELIN, D. (1997) The bidiffractive grating coupler application to immunosensing. Sensors and Actuators B:Chemical 38-39, 256-260.p. DOI: 10.1016/S0925-4005(97)80214-6

STARODUB, N.F., DZANTIEV, B.B., STARODUB, V.M., ZHERDEV, A.V. (2000): Immunosensor for the determination of the herbicide simazine based on an ion-selective fieldeffect transistor. Analytica Chimica Acta 424, 37-43.p. DOI: 10.1016/S0003-2670(00)01143-0

SUMPTER, J.P., JOBLING, S. (1995) Vitellogenesis as a biomarker for estrogenic contamination of the aquatic environment. Environmental Health Perspectives 103, 173-178.p.

SZÉKÁCS, A., TRUMMER, N., ADÁNYI, N., VÁRADI, M., SZENDRÖ, I. (2003) Development of a non-labeled immunosensor for the herbicide trifluralin via OWLS detection. Anal. Chim. Acta 487, 31-42.p. DOI: 10.1016/S0003-2670(03)00302-7

THIEFENTHALER, K., LUKOSZ, W. (1989) Sensitivity of grating couplers as integrated-optical chemicak sensor. Journal of Optical. Society of America B 6 (2) 209-220.p. DOI: 10.1364/JOSAB.6.000209

TRUMMER, N., ADÁNYI, N., VÁRADI, M., SZENDRÖ, I. (2001) Modification of the surface of integrated optical wave-guide sensors for immunosensor applications. FRESENIUS Journal of Analytical Chemistry 371 (1) 21-24.p. DOI: 10.1007/s002160100929

TSCHMELAK, J., KÄPPEL, N., GAUGLITZ, G. (2005) TIRF-based biosensor for sensitive detection of progesterone in milk based on ultra-sensitive progesterone detection in water. Analytical and bioanalytical chemistry 382 (8) 1895-903.p. DOI: 10.1007/s00216-005-3261-x 
TSCHMELAK, J., KUMPF, M., KÄPPEL, N., PROLL, G.,GAUGLITZ, G. (2006) Total internal reflectance fluorescence (TIRF) biosensor for environmental monitoring of testosterone with commercially available immunochemistry: antibody characterization, assay development and real sample measurements. Talanta 69 (2) 343-50.p. DOI: $10.1016 /$ j.talanta.2005.09.048

TUANTRANONT, A., WISITSORA-AT, A., SRITONGKHAM, P., JARUWONGRUNGSEE, K. (2011) A review of monolithic multichannel quartz crystal microbalance: A review. Analytica Chimica Acta 687 114-128.p. DOI: 10.1016/j.aca.2010.12.022

TÜDŐS, A.J., LUCAS-VAN DEN BOS, E.R., STIGTER, E.C.A. (2003) Rapid surface plasmon resonance based inhibition assay of deoxynivalenol. Journal of Agricultural and Food Chemistry 51, 5843-5848.p. DOI: 10.1021/jf030244d

TYLER, C.R., SUMPTER, J.P., KAWAUCHI, H., SWANSON, P. (1991) Involvement of gonadotropin in the uptake of vitellogenin into vitellogenic oocytes of the rainbow trout, Oncorhynchus mykiss. General and Comperative Endocrinology 84 (2) 291-299.p. DOI: $\underline{10.1016 / 0016-6480(91) 90052-8}$

UENO, Y. (1977) Trichothecenes: Overview address. In: Mycotoxins in human and animal health. (Rodricks, J.V., Hesseltine, C.W., Mehlmann, M.A.) Pathotox Publishers, Park Forest South, Illinois 189-228.p.

VAN DER GAAG, B., SPATH, S., DIETRICH, H., STIGTER, E., BOONZAAIJER, G., VAN OSENBRUGGEN, T., KOOPAL, K. (2003) Biosensors and multiple mycotoxin analysis. Food Control 14, 251-254.p. DOI: 10.1016/S0956-7135(03)00008-2

VAN VELD, P.A., RUTAN, P.B., SULLIVAN, C.A., JOHNSTON, L.D., RICE, C.D., FISHER, D.F., YONKOS, L.T. (2005) A universal assay for vitellogenin in fish mucus and plasma. Environmental Toxicology and Chemistry 24, 3048-3052.p. DOI: 10.1897/05-363R.1

VINCENT, S.G.P., KELLER, R., SUBRAMONIAM, T. (2001) Development of Vitellogenin ELISA: an in vivo bioassay and identification of two vitellogenesis inhibiting hormones of the tiger shrimp, Penaeus monodon. Marine Biotechnology 3, 561-571.p. DOI: 10.1007/s10126010066-6

VOLZ, D.C., CHANDLER, G.T. (2004) An enzyme-linked immunosorbent assay for lipovitellin quantification in copepods: A screening tool for endocrine toxicity. Environmental Toxicology and Chemistry 23 (2) 298-305.p. 
VÖRÖS, J., RAMSDEN, J.J., CSÚCS, G., SZENDRÖ, I., DE PAUL, S.M., TEXTOR, M., SPENCER, N.D. (2002) Optical grating coupler biosensors. Biomaterials 23, 3699-3710.p. DOI: $\underline{10.1016 / \mathrm{S} 0142-9612(02) 00103-5}$

WANG, J-H., RUDDOCK, L.W., CASS, A.E.G. (1994) Microscopic investigations of the interaction of proteins with surfaces. Biosensors and Bioelectronics 9, 647-655.p. DOI: $\underline{10.1016 / 0956-5663(94) 80061-8}$

WANG, L., GAN, X.X. (2009) Biomolecule-functionalized magnetic nanoparticles for flowthrough quartz crystal microbalance immunoassay of aflatoxin B1. Bioprocess and Biosystems Engineering 32 (1) 109-116.p. DOI: 10.1007/s00449-008-0228-2

WEETALL, H.H. (1993) Preparation of immobilized proteins covalently coupled through silane coupling agents to inorganic supports. Applied Biochemistry and Biotechnology 41, 157-188.p. DOI: 10.1007/BF02916421

WEETALL, H.H., FILBERT, A.M. (1974) Porous glass for affinity chromatography applications. Methodods in Enzymology 34, 59-72.p. DOI: 10.1016/S0076-6879(74)34007-4

WEISS, R., FREUDENSCHUSS, M., KRSKA, R., MIZAIKOFF, B. (2003) Improving methods of analysis for mycotoxins: molecularly imprinted polymers for deoxynivalenol and zearalenone. Food Additives and Contaminants 20 (4) 386-395.p. DOI: 10.1080/0265203031000065827

WHEELER, J.R., GIMENO, S., CRANE, M., LOPEZ-JUEZ, E., MORRITT, D. (2005) Vitellogenin: A review of analytical methods to detect (anti) estrogenic activity in fish. Toxicology Mechanisms and Methods 15, 293-306.p. DOI: 10.1080/15376520590968789

WHO/FAO (2000): Safety evaluation of certain mycotoxins in food. WHO Food Aditive Series: 47, FAO Food and Nutrition Paper 74, 680.p.

WILLIAMS, R.A., BLANCH, H.W. (1994) Covalent immobilization of protein monolayers for biosensor applications. Biosensors and Bioelectronics 9, 159-167.p. DOI: $\underline{10.1016 / 0956-}$ $\underline{5663(94) 80108-8}$

WILLIAMSON, M.L., ATHA, D.H., REEDER, D.J., SUNDARAM, P.V. (1989) Anti-T2 monoclonal antibody immobilization on quartz fibers: Stability and recognition of T2 mycotoxin. Analytical Letters 22 (4) 803-816.p. DOI: 10.1080/00032718908051368 
YANG, X., ZHI-BING H., QING-HUA, H., SHUN-ZHOU, D., LAI-SHENG, L., YAN-PING, L. (2010) Development of an immunochromatographic strip test for the rapid detection of deoxynivalenol in wheat and maize. Food Chemistry 119 (2) 834-839.p. DOI: $\underline{10.1016 / \text { j.foodchem.2009.08.049 }}$

ZHANG, X., JU, H., WANG, J. (Szerk.) (2008) Electrochemical sensors, Biosensors and their Biomedical applications. Elsevier Inc. 246-253.p.

ZHI-BING, H., YANG, X., LAI-SHENG, L., YAN-PING, L., HONG, Z., QING-HUA, H. (2012) Development of an immunochromatographic strip test for the rapid simultaneous detection of deoxynivalenol and zearalenone in wheat and maize. Food Control 28, 7-12.p. DOI: $\underline{10.1016 / j . f o o d c o n t .2012 .04 .035}$ 


\section{KÖSZÖNETNYILVÁNÍTÁS}

Ezúton szeretném kifejezni köszönetemet témavezetőmnek, Adányiné Dr. Kisbocskói Nórának a disszertáció elkészítéséhez nyújtott szakmai segítségért, támogatásért.

Szeretném megköszönni Prof. Dr. Székács Andrásnak és a projektben résztvevőknek - NAIKAKK GVOP-3.1.1-2004-05-0429/3.0 „Immunteszt és immunszenzor kidolgozása endokrin zavaró hatások biomarker fehérjéjének kimutatására” a vitellogenin kimutatására alkalmas szenzor fejlesztésben való segítséget.

Dr. Habil. Kiss Attilának, hogy a tudományos pályán való elinduláshoz lehetőséget biztosított.

Köszönöm a Biológiai osztály munkatársainak az immunanyagok elöállításában nyújtott segítséget.

Köszönettel tartozom szüleimnek és családomnak, akik mindvégig hittek bennem és támogattak. 